QA: QA

Page i

110-3YD-HT00-00100-000-001

April 2005

\title{
SNF/HLW Transfer System Description Document
}

Prepared for:

U.S. Department of Energy

Office of Civilian Radioactive Waste Management

Office of Repository Development

1551 Hillshire Drive

Las Vegas, Nevada 89134-6321

Prepared by:

Bechtel SAIC Company, LLC

1180 Town Center Drive

Las Vegas, Nevada 89144

Under Contract Number

DE-AC28-01RW12101 


\section{DISCLAIMER}

This report was prepared as an account of work sponsored by an agency of the United States Government. Neither the United States Government nor any agency thereof, nor any of their employees, nor any of their contractors, subcontractors or their employees, makes any warranty, express or implied, or assumes any legal liability or responsibility for the accuracy, completeness, or any third party's use or the results of such use of any information, apparatus, product, or process disclosed, or represents that its use would not infringe privately owned rights. Reference herein to any specific commercial product, process, or service by trade name, trademark, manufacturer, or otherwise, does not necessarily constitute or imply its endorsement, recommendation, or favoring by the United States Government or any agency thereof or its contractors or subcontractors. The views and opinions of authors expressed herein do not necessarily state or reflect those of the United States Government or any agency thereof. 


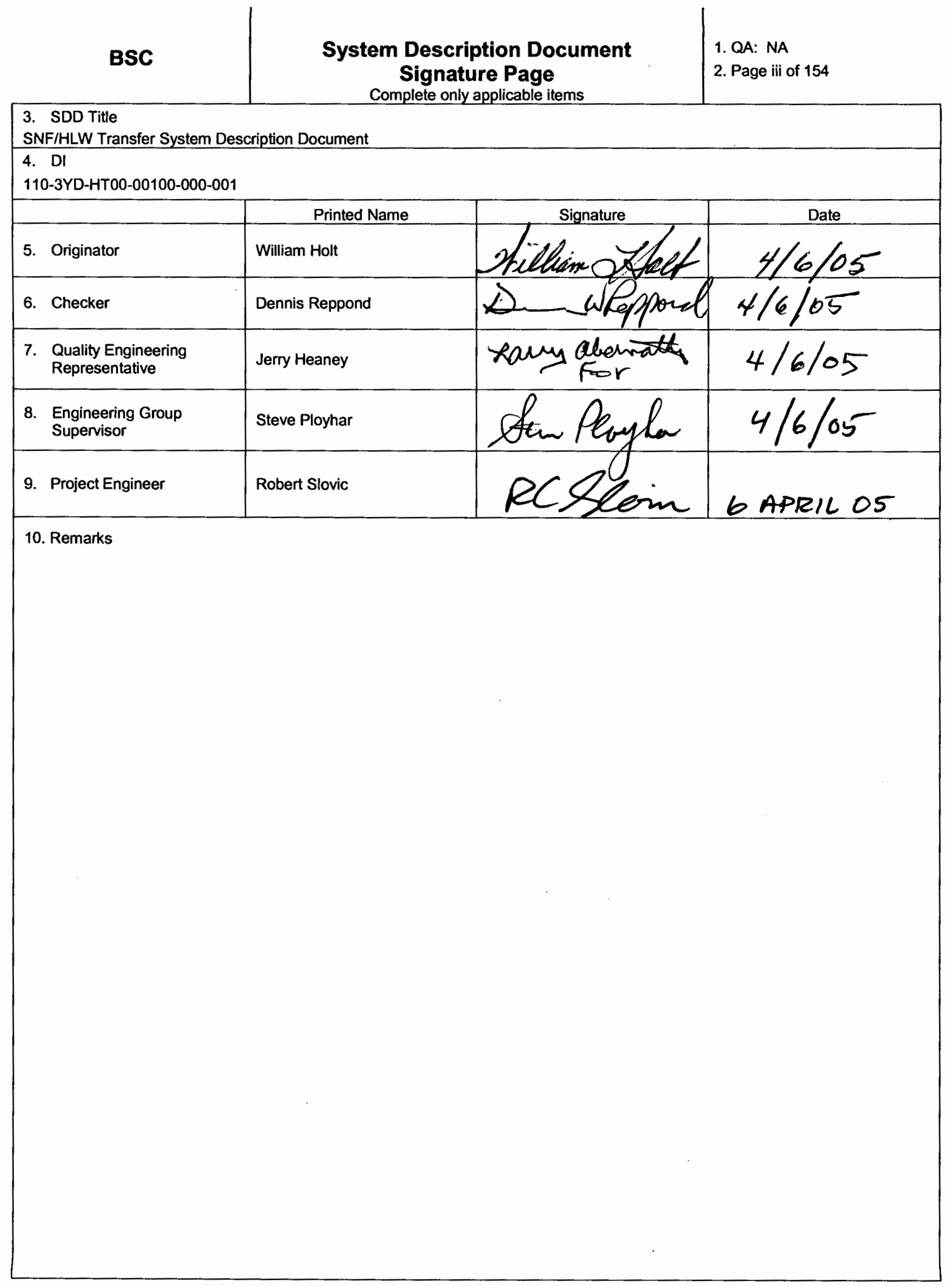




\section{BSC}

\section{System Description Document Change History \\ Complete only applicable items}

11. Page iv of $\mathbf{1 5 4}$

12. SDD Title

SNF/HLW Transfer System Description Document

13. DI

110-3YD-HT00-00100-000-001

14. Revision No.

15. Description of Change

000

Initial Issue

001

Issued for License Application

Add document basis statement that was left out of Rev. 000:

Minor revisions to incorporate: Project Design Criteria Document 000-3DR-MGR0-00100-000-003, Project Functional \& Operational Requirements TDR-MGR-ME-000003 Rev. 02, Q-List 000-30R-MGR0-00500-000-001, and Nuclear Safety Design Basis for License Application 000-30R-MGR0-00400-000-001

Updated Sections 2, 3, 4, and Appendix B

This SDD revision resolves CA 4555-001 for CR 4555 


\section{CONTENTS}

ACRONYMS vii

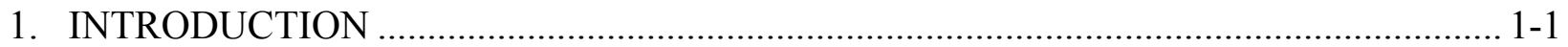

1.1 SYSTEM IDENTIFICATION ........................................................................................ 1-1

1.2 LIMITATIONS OF THIS SYSTEM DESCRIPTION DOCUMENT ……................. 1-4

1.3 OWNERSHIP OF THIS SYSTEM DESCRIPTION DOCUMENT ........................... 1-4

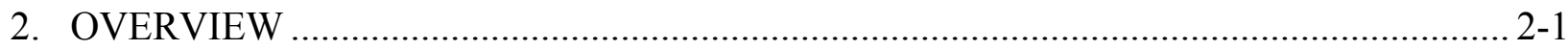

2.1 STRUCTURE, SYSTEM, OR COMPONENT FUNCTIONS................................... 2-1

2.2 STRUCTURE, SYSTEM, OR COMPONENT CLASSIFICATION ......................... 2-2

2.3 OPERATIONAL OVERVIEW ......................................................................... $2-4$

3. REQUIREMENTS AND BASES ………………................................................ $3-1$

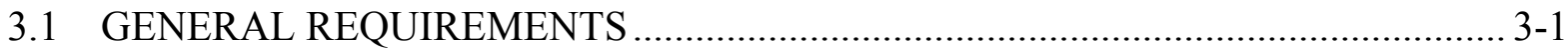

3.2 SPECIAL REQUIREMENTS AND BASES ………....................................... 3-22

3.3 ENGINEERING DISCIPLINARY REQUIREMENTS AND BASES...................... 3-28

3.4 TESTING AND MAINTENANCE REQUIREMENTS AND BASES ..................... 3-31

3.5 OTHER REQUIREMENTS AND BASES ....................................................... 3-32

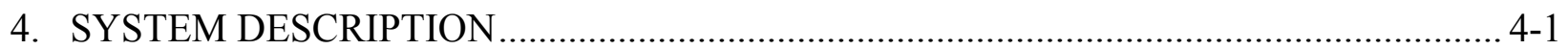

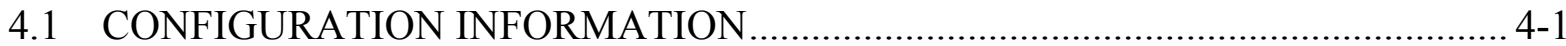

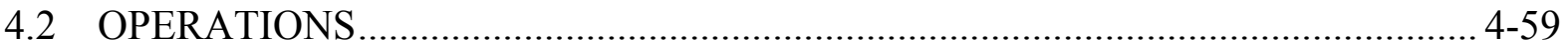

4.3 TESTING AND MAINTENANCE ................................................................... 4-77

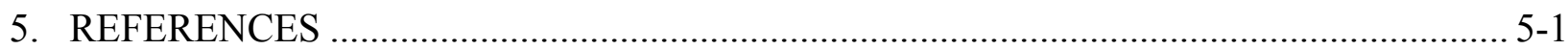

5.1 DOCUMENTS CITED ...................................................................................... 5-1

5.2 CODES, STANDARDS, REGULATIONS, AND PROCEDURES …………............ 5-4

5.3 DATA TRACKING NUMBERS ………………................................................ 5-6

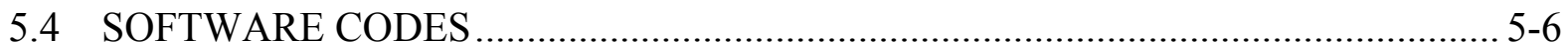

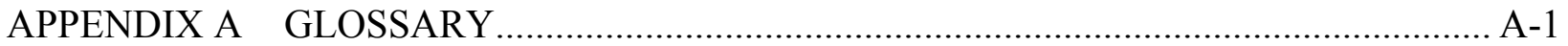

APPENDIX B LIST OF KEY SYSTEM CHARTS, DIAGRAMS, DRAWINGS, LISTS, AND ETC.............................................................................

APPENDIX C LIST OF SYSTEM PROCEDURES …………………………….............. 


\section{FIGURES}

Page

1-1. Process System Identification and Flow of Material .............................................. 1-4

4-1. Key Dry Transfer Facility System Boundaries......................................................... 4-49

4-2 Key Canister Handling Facility System Boundaries ................................................. 4-52

4-3 Key Fuel Handling Facility System Boundaries.................................................. 4-55

B-1. SNF/HLW Transfer System Block Flow Diagram .................................................

\section{TABLES}

Page

2-1. Safety Classification of Subsystems and SSCs................................................. 2-3

4-1. Description of Key Dry Transfer Facility System Interfaces ................................... 4-50

4-2. Description of Key Canister Handling Facility System Interfaces ............................ 4-53

4-3. Description of Key Fuel Handling Facility System Interfaces .................................. 4-55

4-4. Dry Transfer Facility SNF/HLW Transfer System Main Equipment Maintenance ...... 4-78

4-5. Canister Handling Facility SNF/HLW Transfer System Main Equipment Maintenance ................................................................................................ 4-80

4-6. Fuel Handling Facility SNF/HLW Transfer System Main Equipment Maintenance.... 4-81 


\section{ACRONYMS}

\begin{tabular}{|c|c|}
\hline ALARA & as low as is reasonably achievable \\
\hline BSC & Bechtel SAIC Company \\
\hline BWR & boiling water reactor \\
\hline $\mathrm{CHF}$ & Canister Handling Facility \\
\hline CCTV & closed circuit television \\
\hline CSNF & commercial spent nuclear fuel \\
\hline DBGM & design basis ground motion \\
\hline DOE & U.S. Department of Energy \\
\hline $\mathrm{DPC}$ & dual-purpose canister \\
\hline DTF & Dry Transfer Facility \\
\hline F\&OR & Functional and Operational Requirements \\
\hline FHF & Fuel Handling Facility \\
\hline FMEA & failure mode and effects analysis \\
\hline HLW & high-level radioactive waste \\
\hline HVAC & heating, ventilation, and air conditioning \\
\hline $\mathrm{I} \& \mathrm{C}$ & instrumentation and control \\
\hline ITS & important to safety \\
\hline ITWI & important to waste isolation \\
\hline $\mathrm{MCO}$ & multicanister overpack \\
\hline $\mathrm{MSC}$ & repository site-specific cask \\
\hline $\mathrm{NRC}$ & U.S. Nuclear Regulatory Commission \\
\hline PDC & Project Design Criteria Document \\
\hline PRD & Project Requirements Document \\
\hline PWR & pressurized water reactor \\
\hline $\mathrm{SC}$ & safety category \\
\hline SDD & system description document \\
\hline SFTM & spent fuel transfer machine \\
\hline SNF & spent nuclear fuel \\
\hline SSC & structure, system, or component \\
\hline
\end{tabular}




\section{ACRONYMS AND ABBREVIATIONS (Continued)}

TBD to be determined

TCRRF Transportation Cask Receipt/Return Facility

WNNRF Warehouse \& Non-nuclear Receipt Facility

WP waste package

YMP Yucca Mountain Project 


\section{INTRODUCTION}

The purpose of this system description document (SDD) is to establish requirements that drive the design of the spent nuclear fuel (SNF)/high-level radioactive waste (HLW) transfer system and associated bases, which will allow the design effort to proceed to license application. This SDD will be revised at strategic points as the design matures. This SDD identifies the requirements and describes the system design, as it currently exists, with emphasis on attributes of the design provided to meet the requirements. This SDD is an engineering tool for design control. Accordingly, the primary audience and users are design engineers. This SDD is part of an iterative design process. It leads the design process with regard to the flowdown of upper tier requirements onto the system. Knowledge of these requirements is essential in performing the design process. The SDD follows the design with regard to the description of the system. The description provided in this SDD reflects the current results of the design process.

Functional and operational requirements applicable to this system were obtained from Project Functional and Operational Requirements (F\&OR) (Curry 2004 [DIRS 170557]). Other requirements that support the design process were taken from documents such as Project Design Criteria Document (PDC) (BSC 2004 [DIRS 171599]), the fire hazards analyses, and Nuclear Safety Design Bases for License Application (BSC 2005 [DIRS 171512]). These documents address requirements in Project Requirements Document (PRD) (Canori and Leitner 2003 [DIRS 166275]).

This SDD includes several appendices. Appendix A is a glossary; Appendix B is a list of key system charts, diagrams, drawings, lists, and additional supporting information; and Appendix C is a list of procedures that will be used to operate the system.

\subsection{SYSTEM IDENTIFICATION}

The SNF/HLW transfer system encompasses the necessary subsystems and functions to:

- Transfer SNF/HLW from a loaded transportation cask, opened dual-purpose canister (DPC), or repository site-specific cask (MSC) to an empty waste package (WP), empty | or unloaded site-specific cask, or the staging area

- Prepare a DPC for SNF transfer to a waste package, site-specific cask, or staging area

- Transfer a loaded sealed waste package to the waste package transporter

- Transfer SNF/HLW from the staging area to an empty waste package or empty or unloaded site-specific cask

- Offload a waste package requiring remediation from the waste package transporter to the remediation system. 
For the Dry Transfer Facility (DTF), the SNF/HLW transfer system begins with an empty waste package or site-specific cask in the proper position under the docking port and one of the following:

- A loaded transportation cask or site-specific cask under a cask and site-specific cask docking room docking port

- A naval canister cask in the WP loading (navy canister)/docking ring removal cell and a naval waste package in the WP loading/docking ring removal cell

- DPC in a transportation cask under the DPC docking room docking port

The SNF/HLW transfer system ends with one of the following:

- A loaded sealed waste package on the subsurface transport vehicle

- A loaded site-specific cask ready for return to the cask/MSC/WP preparation system.

Loaded transportation casks include commercial SNF (bare or in DPCs), U.S. Department of Energy (DOE) SNF or HLW canisters and Naval Nuclear Propulsion Program canisters. The term "naval canister" is used to indicate Naval Nuclear Propulsion Program canisters within this document.

For the Canister Handling Facility (CHF), the SNF/HLW transfer system begins in the dry transfer subsystem with an empty waste package or an empty or unloaded site-specific cask in its appropriate pit, and a loaded cask or site-specific cask in its appropriate pit. It ends in the waste package loadout subsystem with a sealed waste package in place on the waste package transporter or a loaded site-specific cask ready for return to the cask/MSC/WP preparation system. Loaded casks/site-specific casks include DOE SNF, DOE HLW, naval canisters, and commercial DPCs. The CHF SNF/HLW transfer system also includes staging pits for DOE SNF/HLW canisters. DPCs are not opened in the CHF; they are only transferred from the transportation cask to a site-specific cask for transfer to the SNF aging system. CHF handles vertical DPCs only.

For the Fuel Handling Facility (FHF), the SNF/HLW transfer system begins with loaded transportation casks, empty waste packages, and loaded, empty, or unloaded site-specific casks in the appropriate fuel transfer bays or in the canister transfer station. It ends with a sealed waste package on a waste package transporter ready for emplacement, or a loaded site-specific cask on the surface transporter ready for aging. DPCs are not opened in the FHF; they are only transferred from the transportation cask to a site-specific cask for transfer to the SNF aging system.

The SNF/HLW transfer system consists of the following subsystems:

- DPC cutting subsystem (DTF only)

- Dry transfer subsystem

- Waste package loadout subsystem. 
Throughout this document the DTF implies that all systems are located within either the DTF 1 or the DTF 2. The SNF/HLW transfer system is housed inside the DTF, CHF, and the FHF.

The system interfaces with the following systems and facilities:

- Non-nuclear handling system

- Cask/MSC/WP preparation system

- Remediation system

- Waste package closure system

- Waste package emplacement and retrieval system

- Digital control and management information system

- Radiation and radiological monitoring system

- Electrical power system

- Electrical support system

- Plant services system

- Communications system

- Fire protection system

- Safeguards and security system

- Dry Transfer Facility

- Fuel Handling Facility

- Canister Handling Facility

- Remediation system

- Balance of Plant Facility

- Surface nuclear heating, ventilation, and air-conditioning (HVAC)

- Surface industrial HVAC

- Waste package system

- Low-level radioactive waste generating system

- Low-level radioactive waste management system 
Figure 1-1 below provides a view of how the flow of material through the SNF/HLW transfer | system interfaces with other process systems of the repository.

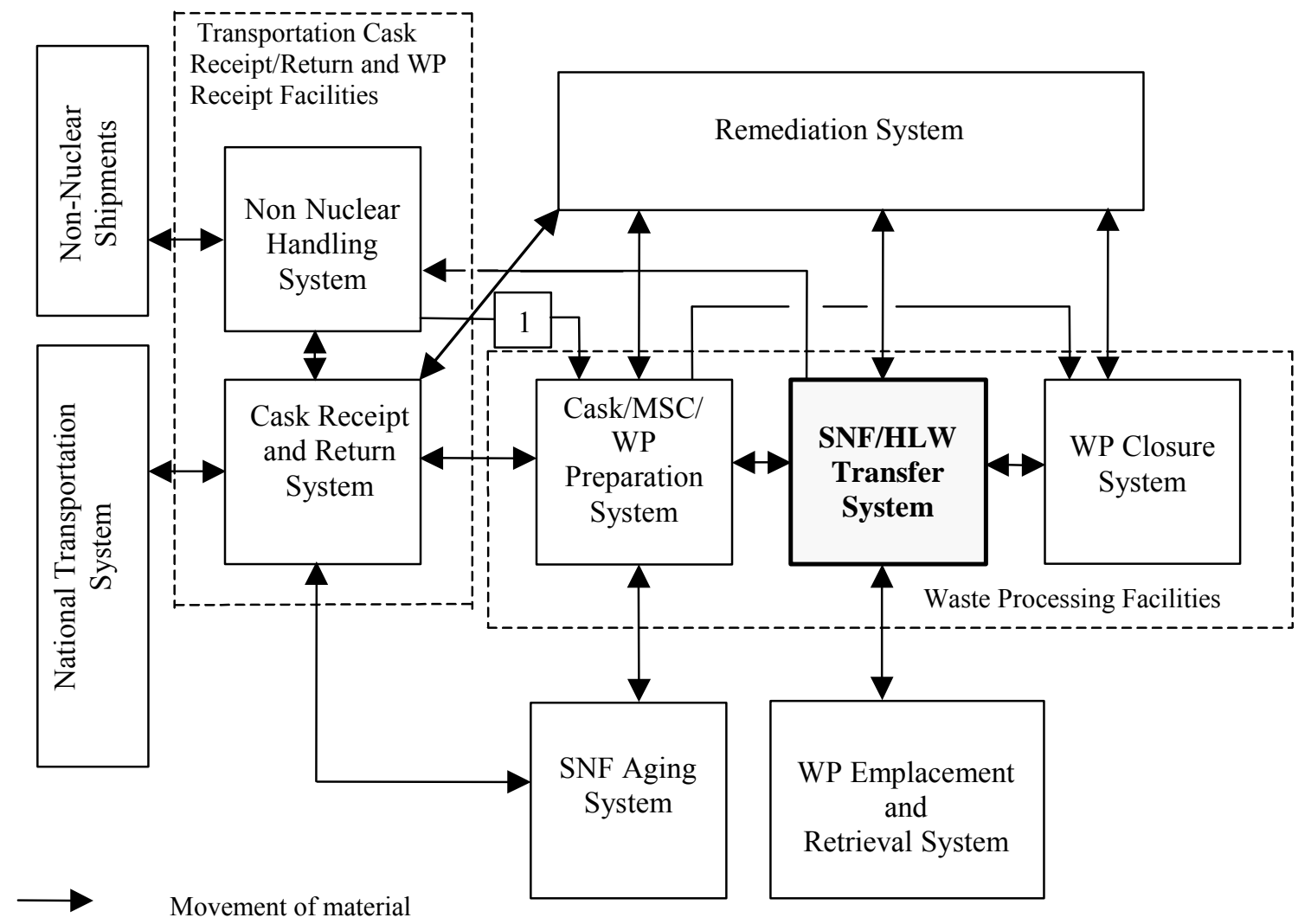

NOTE: 1 . Waste packages and empty site-specific casks are delivered directly to the FHF from the Non-nuclear handling system.

Figure 1-1. Process System Identification and Flow of Material

\subsection{LIMITATIONS OF THIS SYSTEM DESCRIPTION DOCUMENT}

This SDD may include assumptions, preliminary information, and to be verified values, as appropriate, to the current level of design development. Additionally, requirements or descriptions that are stated as to be determined (TBD) or are expected at a later phase of the design will be described as such.

When this version was approved, the design status was such that the conceptual design had been completed and the preliminary design had begun. As design documents (e.g., calculations, drawings, and specifications) are completed, the description of the SNF/HLW transfer system design will be updated.

\subsection{OWNERSHIP OF THIS SYSTEM DESCRIPTION DOCUMENT}

The SNF/HLW transfer system SDD is owned by the Mechanical Handling and Waste Systems Group of Design Engineering. 


\section{OVERVIEW}

This section lists the functions of the SNF/HLW transfer system that are traceable to the requirements in the F\&OR (Curry 2004 [DIRS 170557]). This section also documents a preliminary determination of the system classification and provides an overview of the system operation.

\subsection{STRUCTURE, SYSTEM, OR COMPONENT FUNCTIONS}

The SNF/HLW transfer system is described as follows in Section 1.1.2 of the F\&OR (Curry 2004 [DIRS 170557]):

The package SNF/HLW function provides for the SNF/HLW shipped to the repository to be removed from the transportation cask, placed in an approved waste package or site-specific cask, and sealed in the waste package or site-specific cask. This function begins with a shipment of $\mathrm{SNF} / \mathrm{HLW}$ received at the repository and ends with an unloaded transportation cask and a sealed waste package ready to be emplaced.

The SNF/HLW transfer system functions begin with a loaded transportation cask, DPC, or site-specific cask, and an empty waste package or empty or unloaded site-specific cask in the proper positions. The system ends with an unloaded transportation cask, site-specific cask, or DPC and a loaded site-specific cask for SNF aging or a sealed waste package ready to be emplaced. These functions are applicable to the DTF, CHF, and FHF, unless otherwise specified.

\subsubsection{Prepare Transportation Casks, Waste Packages, Site-Specific Casks, and Dual- Purpose Canisters for Spent Nuclear Fuel/High-Level Waste Transfer [F\&OR 1.1.2.1]}

The prepare transportation cask, waste packages, site-specific casks, and DPCs for SNF/HLW transfer function embodies all activities to prepare casks, waste packages, site-specific casks, and DPCs for transfer operations, including accessing the inside of the cask or DPC, positioning the respective component for transfer operations, and achieving radiological confinement with the transportation cask, waste package, site-specific cask, and/or open and ready for SNF/HLW transfer.

The SNF/HLW transfer system addresses the portion of this function that requires preparing the DPC for transfer operations, including sampling, opening, positioning, and radiological confinement of a DPC. DPC cutting activities are applicable to DTF only. Achieving radiological confinement is only done in DTF and FHF for transfer of bare SNF.

\subsubsection{Transfer Contents of Cask to Waste Package, Staging Area, Dual-Purpose Canister Handling Area, or Site-Specific Cask [F\&OR 1.1.2.2]}

The transfer contents of cask to waste package, staging area, DPC handling area, or site-specific cask function embodies all activities necessary to remove SNF/HLW from the transportation cask, opened DPCs, or site-specific casks; load the SNF/HLW into a waste package; and prepare the waste package for sealing. This function begins with a loaded transportation cask, opened DPC, or loaded site-specific cask and an empty waste package or empty or unloaded site-specific 
cask in the proper positions and ends with SNF/HLW loaded into the waste package or site-specific cask and the unloaded transportation cask, DPC, or site-specific cask removed from the transfer area.

\subsubsection{Emplace and Retrieve Sealed Waste Package [F\&OR 1.1.3 ]}

The emplace and retrieve sealed waste package function transports the waste package from the surface to its selected location within an emplacement drift, leaves the waste package in the emplacement drift, and returns the transport vehicle(s) to the surface. This function begins with a sealed waste package at the surface and ends when the waste package is emplaced, and the unloaded subsurface transporter(s) is returned to the surface for redeployment.

The SNF/HLW transfer system addresses the loadout of sealed waste packages and unloading of retrieved sealed waste package portion of this function. During the preclosure phase of the repository, the SNF/HLW transfer system must have equipment and processes available for offloading and retrieved waste packages [F\&OR 1.1.3.11] when returned to DTF. The SNF/HLW transfer system must perform radiological survey and decontamination, if necessary; identification confirmation, ancillary component installation and removal, waste package opening, and fuel transfer, if required; and waste package transporter loading at completion of | retrieval scenario.

\subsubsection{Recover from Off-Normal Events [F\&OR 1.1.4]}

The recover from off-normal events function assures the continued operation of the repository while maintaining the required levels of safety and security. As a general rule, the off-normal condition must be identified, assessed, mitigated, and resolved, providing feedback to the affected process owners to prevent recurrence. These conditions may be further categorized as site area emergencies and alerts, both of which are not mutually exclusive.

\subsubsection{Control Spent Nuclear Fuel/High-Level Waste Handling Operations [F \& OR 1.1.6]}

The repository shall control all aspects of SNF/HLW handling operations, including material and equipment movement, criticality, quality of sealing, radiological confinement, and nuclear material inventories.

\subsection{STRUCTURE, SYSTEM, OR COMPONENT CLASSIFICATION}

In accordance with the Q-List (BSC 2005 [DIRS 171190]) and Table A-II of Nuclear Safety Design Bases for License Application, (BSC 2005 [DIRS 171512]), the SNF/HLW transfer system is safety category (SC) since there are event sequences that credit the performance of the system. Because of the possibility of dropping a waste package, bare fuel element or SNF/HLW canister, handling equipment is SC and, therefore, important to safety (ITS). Table 2-1 identifies the safety classification of the subsystems and structure, system, or components (SSCs) for the $\mathrm{SNF} / \mathrm{HLW}$ transfer system. 
Table 2-1. Safety Classification of Subsystems and SSCs

\begin{tabular}{|c|c|c|c|}
\hline \multicolumn{4}{|l|}{ SNF/HLW Transfer System } \\
\hline Name & ITS & ITWI & Safety Category \\
\hline Dry Transfer Subsystem & Yes & No & $\mathrm{SC}$ \\
\hline $\begin{array}{l}\text { - Spent Fuel Transfer Machine and Grapples (DTF, } \\
\text { FHF) }\end{array}$ & Yes & No & SC \\
\hline - Canister/HLW Handling Crane (DTF) 70-ton & Yes & No & SC \\
\hline - Naval Canister Handling Crane (DTF) 70-ton & Yes & No & $\mathrm{SC}$ \\
\hline - Cask/Waste Package Docking Station (DTF, FHF) & Yes & No & $\mathrm{SC}$ \\
\hline $\begin{array}{l}\text { - Canister and SNF Handling Grapples (DTF, FHF, } \\
\text { CHF) }{ }^{a}\end{array}$ & Yes & No & $\mathrm{SC}$ \\
\hline - Canister and SNF Staging Racks (DTF, CHF) & Yes & No & $\mathrm{SC}$ \\
\hline - Crane Lifting Yokes (DTF, FHF, CHF) & Yes & No & $\mathrm{SC}$ \\
\hline Waste Package Loadout Subsystem & Yes & No & $\mathrm{SC}$ \\
\hline - Waste Package Handling Crane (DTF) 100-ton & Yes & No & $\mathrm{SC}$ \\
\hline $\begin{array}{l}\text { - Waste Package Loadout Handling Crane (DTF) } \\
\text { 100-ton }\end{array}$ & Yes & No & SC \\
\hline - Fuel Transfer Maintenance Crane (FHF) 30-ton ${ }^{a}$ & Yes & No & $\mathrm{SC}$ \\
\hline $\begin{array}{l}\text { - Trolleys, Pedestals, and Hold Down Devices } \\
\text { (DTF, CHF, FHF) }\end{array}$ & Yes & No & SC \\
\hline - Waste Package Tilting Machine (DTF, FHF, CHF) & Yes & No & $\mathrm{SC}$ \\
\hline - Waste Package Turntable (DTF, FHF, CHF) & Yes & No & $\mathrm{SC}$ \\
\hline $\begin{array}{l}\text { - Trunnion Collar Removal Machine } \\
\text { (DTF, FHF, CHF) }\end{array}$ & Yes & No & SC \\
\hline - Waste Package Lifting Yokes (DTF, CHF, FHF) & Yes & No & $\mathrm{sC}$ \\
\hline - Waste Package Pallet Lifting Yokes (CHF, FHF) ${ }^{a}$ & Yes & No & $\mathrm{SC}$ \\
\hline Dual-Purpose Canister Cutting Subsystem (DTF) & Yes & No & SC \\
\hline - DPC Cutting Station (DTF) ${ }^{a}$ & Yes & No & SC \\
\hline - DPC and Canister Cutting Machine (DTF) & Yes & No & $\mathrm{SC}$ \\
\hline - DPC Docking Station (DTF) & Yes & No & $\mathrm{SC}$ \\
\hline
\end{tabular}
ITWI = important to waste isolation.

Additional information regarding system classification may be found in Q-List (BSC 2005 [DIRS 171190]), Safety Classification of SSCs and Barriers (BSC 2005 [DIRS 171668]), and Nuclear Safety Design Bases for License Application (BSC 2005 [DIRS 171512]).

The SNF and canister staging areas in DTF and canister staging area in CHF are ITS for criticality control and to assure cooling of the SNF to control concrete temperatures and fuel assembly cladding temperatures. 


\subsection{OPERATIONAL OVERVIEW}

The SNF/HLW transfer system consists of structures, systems, or components (SSCs) necessary to transfer waste into waste packages and site-specific casks and to prepare loaded and sealed waste packages for delivery to the emplacement and retrieval system. In addition, the system consists of the SSCs that are used to open dual-purpose canisters in support of waste transfer operations.

The following sections describe the system from an operational viewpoint. Specific operational actions, scope of inspections and evaluations, acceptance criteria, and other operations management details will be defined in operating procedures, inspection plans and procedures, Environmental Health and Safety plans, and other controlling documents prepared by the operating contractor.

The SNF/HLW transfer system is divided into three subsystems:

1. DPC cutting subsystem (DTF only)

2. Dry transfer subsystem

3. Waste package loadout subsystem.

An operational overview of each subsystem is provided below. Further details of each subsystem are provided in Section 4.

\subsubsection{Dual-Purpose Canister Cutting Subsystem}

This subsystem, located in DTF only, is designed to perform the following functions:

- Dock a transportation cask or site-specific cask containing a DPC to the DPC cutting/WP dry remediation cell

- Transfer DPCs within the DPC cutting cell/WP dry remediation cell to the cutting station and unloading area

- Sample DPC cavity and vent

- Open DPCs to allow the transfer of SNF

- Prepare the unloaded DPC for processing as low-level radioactive waste.

A transportation cask or site-specific cask containing a DPC is delivered to the DPC cutting subsystem from the cask/MSC/WP preparation system. The transportation cask or site-specific cask containing a DPC is on a trolley that is positioned under the docking station in the DPC docking room. The transportation cask or site-specific cask is docked and confinement is established between the cask and DPC cutting/WP dry remediation cell. The DPC is transferred from the transportation cask or site-specific cask to the DPC cutting/WP dry remediation cell using the waste package remediation crane. The waste package remediation crane is part of the remediation system. The DPC is moved to the DPC cutting station where sampling and venting of the gas inside the DPC take place. The DPC lid is removed, and the opened DPC is then 
moved to the DPC unloading area. The unloading area hatch is removed, and the contents of the DPC are removed by the dry transfer subsystem. After unloading is complete, the waste package remediation crane transfers the unloaded DPC into an overpack that has been docked at the DPC docking port in the DPC docking room. The DPC cask docking station provides an interface between the DPC docking room, DPC cutting/WP dry remediation cell. The DPC cask docking station is similar to the cask and waste package docking stations. The overpack with unloaded DPC inside is then transferred to the low-level waste management system for offsite disposal.

\subsubsection{Dry Transfer Subsystem}

This subsystem is designed to perform the following functions:

- Receive transportation casks, site-specific casks, and empty waste packages and provide docking of the transportation casks, site-specific casks and waste packages within the waste transfer cell (DTF). Receive transportation casks, site-specific casks, and empty waste packages into pits in the canister transfer area (CHF). Receive transportation casks, site-specific casks, and empty waste packages into the fuel transfer bays and provide docking of the casks, site-specific casks and waste packages within the fuel transfer room for bare SNF (FHF).

- Provide confinement between the transportation cask, site-specific cask, or waste package and the waste transfer cell (DTF) and fuel transfer room (FHF).

- Transfer canistered and uncanistered SNF and HLW between transportation casks, site-specific casks, DPCs, waste packages, staging area, and waste transfer cell (DTF). Transfer canistered SNF and HLW between transportation casks, site-specific casks, waste packages, or staging area (CHF). Transfer canistered SNF and HLW or bare fuel assemblies from loaded casks or site-specific casks to empty waste packages or empty or unloaded site-specific casks (FHF).

- Prepare loaded waste packages for transport out of waste transfer operations, including inspection of waste package sealing surfaces, replacement of waste package inner lid, and actuation of restraint mechanism for fuel containment during movement to closure cell (DTF, CHF, and FHF).

\subsubsection{Dry Transfer Facility}

The dry transfer subsystem receives transportation casks, loaded, empty, or unloaded site-specific casks, and empty waste packages at their respective docking stations from the cask/MSC/WP preparation system. The same docking port design principle is used for transportation casks, site-specific casks, and waste packages. Two docking stations are provided for either transportation casks or site-specific casks. Two docking stations are also provided for waste packages. Confinement is established between the transportation casks, site-specific casks, or waste packages and the waste transfer cell through the use of docking rings. 
One unloading station, the WP loading (navy canister)/docking ring removal cell, is provided for naval casks. Naval casks and waste packages receiving naval canisters do not use docking rings or interface with the waste transfer cell.

Opened DPCs are received by the dry transfer subsystem from the DPC cutting subsystem. One unloading port is provided for opened DPCs between the waste transfer cell and the DPC cutting/WP dry remediation cell. Opened DPCs do not use a docking system because the DPC cutting/WP dry remediation cell and the waste transfer cell are in the same designated HVAC primary confinement zone. This port is also used to unload a remediated waste package.

The transfer of the various waste forms by the dry transfer subsystem is performed with several different devices. The spent fuel transfer machine (SFTM) transfers bare SNF assemblies between transportation casks, opened DPCs, site-specific casks, waste packages, and staging racks inside the waste transfer cell. The canister/HLW handling crane transfers DOE SNF/HLW canisters and commercial DPCs when required. The navy canister handling crane transfers naval | canisters from transportation casks to waste packages.

Each waste transfer device has a variety of grapples to accommodate all the waste forms that it is designed to handle.

\subsubsection{Canister Handling Facility}

The dry transfer subsystem in the CHF receives transportation casks, loaded, empty, or unloaded site-specific casks, and empty waste packages at their respective loading stations from the cask/MSC/WP preparation system. One design input for the CHF is that only canisterized waste will be accepted and if a defective canister is detected during cask cavity gas sampling the cask and defective canisters are routed to the remediation system for processing. Therefore, the facility has a low potential for contamination and no confinement is necessary in the transfer area. However, because of high radiation, no personnel are allowed in the canister transfer area while a canister or loaded waste package is being handled.

For transportation casks/site-specific casks containing DOE SNF/HLW canisters, following placement in the cask preparation pit and completion of cask preparation activities, including cask gas sampling, the transportation cask/site-specific cask lid is removed. The canisters are transferred from the transportation cask/site-specific cask into a waste package or staging pit using the waste package and canister handling crane. The empty cask/site-specific cask or loaded site-specific cask lids are replaced and the transportation cask or site-specific cask is returned to the cask/MSC/WP preparation system. The waste package inner lid is replaced, the waste package moves to a waste package positioning cell (under the closure cells) by the waste package and canister handling crane and the waste package trolley.

\subsubsection{Fuel Handling Facility}

The dry transfer subsystem in the FHF receives transportation casks, site-specific casks, and empty waste packages from the cask/MSC/WP preparation system at their respective docking stations. The same docking port design is used for transportation casks, site-specific casks, and waste packages. Three docking stations, one each in Fuel transfer bay \#1, \#2, and \#3, are 
provided. Docking rings are used to provide confinement between the transportation casks, site-specific casks, waste packages, fuel transfer room, and the fuel transfer bays.

A canister transfer station is provided in the main transfer room and contains two stations that will accept transportation casks, loaded, empty, or unloaded site-specific casks, and empty waste packages at their respective loading stations. The canister transfer station positions casks containing canistered fuel (except multicanister overpacks [MCOs]) for transfer to site-specific casks or waste packages. If a defective canister is detected during cask cavity gas sampling, the cask and defective canister are routed to the remediation system for processing, if available, or to a suitable area for storage, e.g. aging pad, until the remediation system is constructed and operational. Therefore, the room has a low potential for contamination and no confinement is necessary between the cask and the main transfer room. However, because of the potential for high radiation, personnel are not allowed in the main transfer room while handling a canister or loaded waste package.

Transfer of the various waste forms by the dry transfer subsystem is performed with several different handling devices. The spent fuel transfer machine transfers bare SNF assemblies between transportation casks, site-specific casks, and waste packages inside the fuel transfer room. The main transfer room crane transfers canistered SNF/HLW between transportation casks, site-specific casks, and waste packages inside the main transfer room.

Each waste transfer handling device has a variety of grapples to accommodate all the waste forms that it is designed to handle.

\subsubsection{Waste Package Loadout Subsystem}

This subsystem is designed to perform the following functions:

- Prepare loaded waste packages for transfer to the waste package transporter after closure

- Receive and stage waste packages after closure (DTF only)

- Prepare and transfer waste packages to the emplacement and retrieval system

- Receive retrieved waste packages from emplacement and retrieval system for transfer to remediation (DTF only).

\subsubsection{Dry Transfer Facility}

The waste package loadout subsystem receives the loaded and sealed waste package from the waste package closure system. Following closure activities by the waste package closure system, the sealed waste package is moved from the waste package positioning cell to the waste package staging and handling cell. The waste package is visually inspected, surveyed for contamination, and decontaminated, if necessary. Upon satisfactory completion of these operations, the waste package is moved to the tilting station where it is tilted to a horizontal position onto the emplacement pallet. 
These movements are performed using a combination of trolley movements and waste package handling crane lifts. Waste packages may be placed on a trolley that goes to the WP/trolley decontamination room if additional decontamination is necessary.

When the sealed waste package is authorized for emplacement, the waste package is moved from the waste package handling and staging cell to the waste package loadout cell. Tilting operations are performed to place the waste package in a horizontal position on the emplacement pallet. The waste package trunnion collars are removed and the emplacement pallet and waste package are loaded onto the waste package transporter.

\subsubsection{Canister Handling Facility}

The waste package loadout subsystem receives the loaded and sealed waste package from the waste package closure system after closure is completed. The waste package is moved from the waste package positioning cell into the CHF waste package survey area. The waste package is then visually inspected and surveyed for contamination. Upon satisfactory completion of these checks, the waste package is moved to the tilting station where it is tilted to horizontal onto the emplacement pallet.

The trunnion collars are removed from the waste package and the waste package is moved with its emplacement pallet onto the waste package transporter.

\subsubsection{Fuel Handling Facility}

The waste package loadout subsystem receives the loaded and sealed waste package from the waste package closure system. After waste package closure is completed by the waste package closure system, the waste package is moved from the waste package positioning cell into the main transfer room.

The waste package is visually inspected, surveyed for contamination, and decontaminated if necessary. Upon satisfactory completion of these operations, the waste package is tilted to a horizontal position and placed onto the emplacement pallet.

The trunnion collars are removed from the waste package and the waste package is moved with its emplacement pallet onto the waste package transporter. 


\section{REQUIREMENTS AND BASES}

All requirements referencing Nuclear Safety Design Bases for License Application (BSC 2005 [DIRS 171512]) are classified as 10 CFR Part 63 [DIRS 173164] requirements and are located in Section 3.1.1.1. The remaining requirements and associated bases are classified as external compliance unless noted within the appropriate comment section.

\subsection{GENERAL REQUIREMENTS}

General functional and performance requirements that are applicable to the entire system are presented in Section 3.1.1. Requirements that apply to the subsystems or to major components within these subsystems are presented in Section 3.1.2. The requirements flow from higher levels to the lower levels following an outline numbering system. For example, requirement 3.1.1.1.4.1 is a lower level requirement that results from higher level requirement 3.1.1.1.4. Some lower level, subsystem requirements may flow down from general requirements contained in Section 3.1.1.

\subsubsection{System Functional Requirements}

\subsubsection{Safety Requirements}

Safety requirements in Section 3.1.1.1 are nuclear design bases from Table A-II of the Nuclear Safety Design Basis for License Application (BSC 2005 [DIRS 171512]). Other requirements that address safety issues such as personnel protection from process industrial hazards or nuclear criticality safety requirements are contained in the special requirements section or other topical section below. In this section the definitions of safety functions delineated by quotation marks are contained in Appendix B of the Nuclear Safety Design Bases for License Application.

3.1.1.1.1 Requirement: Upon a loss of power, the crane shall be designed to stop, retain its load, and enter a locked mode; upon a restoration of power, the cranes shall stay in the locked mode until operator action is taken. This requirement applies to the DTF canister/HLW handling crane, DTF navy canister handling crane, DTF waste package loadout handling crane, and DTF waste package handling crane. Supports Functions 2.1.4 and 2.1.5.

Basis: This safety requirement is identified in Nuclear Safety Design Bases for License Application (BSC 2005 [DIRS 171512], Table A-II).

3.1.1.1.2 Requirement: The conditional probability of the crane exceeding a lift-height limit, given that a drop has occurred, of less than or equal to $1 \times 10^{-4}$. This requirement applies to the DTF waste package handling crane, DTF waste package loadout handling crane, DTF canister/HLW handling crane, and DTF navy canister handling crane. Supports Functions 2.1.3 and 2.1.5.

Basis: This safety requirement is identified in Nuclear Safety Design Bases for License Application (BSC 2005 [DIRS 171512], Table A-II).

3.1.1.1.3 Requirement: The lift height limits for the sealed and unsealed, loaded waste packages handled by the crane are provided in the Nuclear Safety Design Bases, Table C-1 in 
Appendix C (BSC 2005 [DIRS 171512]). This requirement applies to the DTF waste package handling crane. Supports Function 2.1.5.

Comment: The seal and unsealed, loaded waste packages handled by the crane include:

1. Unsealed, loaded waste packages containing commercial SNF, standardized DOE SNF canisters, DOE HLW canisters, naval SNF canisters, or DOE MCOs

2. Sealed waste packages containing commercial SNF, standardized DOE SNF canisters, DOE HLW canisters, naval SNF canisters, or DOE MCOs.

Basis: This safety requirement is identified in Nuclear Safety Design Bases for License Application (BSC 2005 [DIRS 171512], Table A-II).

3.1.1.1.4 Requirement: The probability of dropping handling equipment from the crane onto a canister shall be less than or equal to $1 \times 10^{-5}$ for each canister transferred. This requirement applies to the DTF canister/HLW handling crane. Supports Functions 2.1.4 and 2.1.5.

Basis: This safety requirement is identified in Nuclear Safety Design Bases for License Application (BSC 2005 [DIRS 171512], Table A-II).

3.1.1.1.5 Requirement: The crane shall not be capable of exerting sufficient force to breach a canister as the result of attempts to overcome mechanical constraints. This requirement applies to the DTF canister/HLW handling crane and DTF navy canister handling crane. Supports Functions 2.1.4 and 2.1.5.

Basis: This safety requirement is identified in Nuclear Safety Design Bases for License Application (BSC 2005 [DIRS 171512], Table A-II).

3.1.1.1.6 Requirement: In the event of a credible fire in an area where waste forms are present, the temperature of the crane that handles or transports SNF/HLW shall not reach a level that would make it drop its load. This requirement applies to the DTF canister/HLW handling crane, DTF navy canister handling crane, DTF waste package loadout handling crane and DTF waste package handling crane. Supports Functions 2.1.4 and 2.1.5.

Basis: This safety requirement is identified in Nuclear Safety Design Bases for License Application (BSC 2005 [DIRS 171512], Table A-II).

3.1.1.1.7 Requirement: A drop of a load from the crane that handles SNF/HLW due to a spurious signal caused by a fire shall have a probability of less than $1 \times 10^{-4}$ over the life of the facility. This requirement applies to the DTF canister/HLW handling crane, DTF navy canister handling crane, DTF waste package loadout handling crane and DTF waste package handling crane. Supports Functions 2.1.4 and 2.1.5.

Basis: This safety requirement is identified in Nuclear Safety Design Bases for License Application (BSC 2005 [DIRS 171512], Table A-II).

3.1.1.1.8 Requirement: The crane shall not be capable of exerting sufficient force to breach a waste package as the result of attempts to overcome mechanical constraints. This requirement 
applies to the DTF waste package loadout handling crane and DTF waste package handling crane. Supports Functions 2.1.4 and 2.1.5.

Basis: This safety requirement is identified in Nuclear Safety Design Bases for License Application (BSC 2005 [DIRS 171512], Table A-II).

3.1.1.1.9 Requirement: The crane system shall be designed for loading conditions associated with a DBGM-2 seismic event and maintain its load. In addition, an analysis shall demonstrate that this crane system has sufficient design margin to ensure that a "no drop" safety function is maintained for loading conditions associated with a BDBGM seismic event. This requirement applies to the DTF canister/HLW handling crane, DTF navy canister handling crane, DTF waste package handling crane, and DTF waste package loadout handling crane. Supports Functions 2.1.4 and 2.1.5.

Basis: This safety requirement is identified in Nuclear Safety Design Bases for License Application (BSC 2005 [DIRS 171512], Table A-II).

3.1.1.1.10 Requirement: The lift heights for the canisters handled by the crane; including the DOE MCO, standardized DOE SNF canister, and DOE HLW canister; are provided in the Nuclear Safety Design Bases, Table C-1 in Appendix C (BSC 2005 [DIRS 171512]). This requirement applies to the DTF canister/HLW handling crane. Supports Functions 2.1 .2 and 2.1.5.

Basis: This safety requirement is identified in Nuclear Safety Design Bases for License Application (BSC 2005 [DIRS 171512], Table A-II).

3.1.1.1.11 Requirement: The crane shall not be capable of moving above a speed limit for overhead crane transfers such that a collision at the speed limit would not breach a loaded, sealed waste package. This requirement applies to the DTF waste package loadout handling crane, and DTF waste package handling crane. Supports Functions 2.1.4 and 2.1.5.

Basis: This safety requirement is identified in Nuclear Safety Design Bases for License Application (BSC 2005 [DIRS 171512], Table A-II).

3.1.1.1.12 Requirement: The lift height limits for the sealed waste packages containing commercial SNF, standardized DOE SNF canisters, DOE HLW canisters, naval SNF canisters, and DOE MCOs handled by the crane are provided in the Nuclear Safety Design Bases, Table C-1 in Appendix C (BSC 2005 [DIRS 171512]). This requirement applies to the DTF waste package loadout handling crane. Supports Functions 2.1.3 and 2.1.5.

Basis: This safety requirement is identified in Nuclear Safety Design Bases for License Application (BSC 2005 [DIRS 171512], Table A-II).

3.1.1.1.13 Requirement: The drop rate for cranes involved in handling waste forms and their associated containers shall be less than or equal to $1 \times 10^{-5}$ drops/transfer, regardless of cause, including human error, failure of equipment such as yokes and grapples, or a combination of the two. This requirement applies to the DTF canister/HLW handling crane, DTF navy canister handling crane, DTF waste package loadout handling crane, and DTF waste package handling crane. Supports Functions 2.1.4 and 2.1.5. 
Basis: This safety requirement is identified in Nuclear Safety Design Bases for License Application (BSC 2005 [DIRS 171512], Table A-II).

3.1.1.1.14 Requirement: The crane shall not be capable of moving above a speed limit for overhead crane transfers such that a collision at the speed limit would not breach a standardized DOE SNF canister, a DOE HLW canister, or a DOE MCO. This requirement applies to the DTF canister/HLW handling crane. Supports Functions 2.1.4 and 2.1.5.

Basis: This safety requirement is identified in Nuclear Safety Design Bases for License Application (BSC 2005 [DIRS 171512], Table A-II).

3.1.1.1.15 Requirement: The lift heights for the naval SNF canisters handled by this crane are provided in the Nuclear Safety Design Bases, Table C-1 in Appendix C (BSC 2005 [DIRS 171512]). This requirement applies to the DTF navy canister handling crane. Supports Functions 2.1.4 and 2.1.5.

Basis: This safety requirement is identified in Nuclear Safety Design Bases for License Application (BSC 2005 [DIRS 171512], Table A-II).

3.1.1.1.16 Requirement: The crane shall not be capable of moving above a speed limit for overhead crane transfers such that a collision at the speed limit would not breach a naval SNF canister. This requirement applies to the DTF navy canister handling crane. Supports Functions 2.1.4 and 2.1.5.

Basis: This safety requirement is identified in Nuclear Safety Design Bases for License Application (BSC 2005 [DIRS 171512], Table A-II).

3.1.1.1.17 Requirement: A tipover and breach of a cask while on machinery that transports SNF/HLW due to uncontrolled movements produced by a loss of power or a spurious signal caused by a fire shall have a probability of less than $1 \times 10^{-4}$ over the life of the facility. This requirement applies to the DTF trolleys, pedestals, and hold-down devices. Supports Function 2.1.5.

Basis: This safety requirement is identified in Nuclear Safety Design Bases for License Application (BSC 2005 [DIRS 171512], Table A-II).

3.1.1.1.18 Requirement: The trolley shall be designed with an inherent speed limit such that a collision at the trolley speed limit would not cause the trolley to drop its load. This requirement applies to the DTF trolleys, pedestals, and hold-down devices. Supports Function 2.1.5.

Basis: This safety requirement is identified in Nuclear Safety Design Bases for License Application (BSC 2005 [DIRS 171512], Table A-II).

3.1.1.1.19 Requirement: Upon a loss of power, the trolley shall be designed to stop, retain its load, and enter a locked mode; upon a restoration of power, the trolley shall stay in the locked mode until operator action is taken. This requirement applies to the DTF trolleys. Supports Functions 2.1.4 and 2.1.5.

Basis: This safety requirement is identified in Nuclear Safety Design Bases for License Application (BSC 2005 [DIRS 171512], Table A-II). 
3.1.1.1.20 Requirement: The trolley system shall be designed for loading conditions associated with DBGM-2 seismic event to maintain trolley stability and prevent waste container slapdown. In addition, an analysis shall demonstrate that the trolley system has sufficient seismic design margin to ensure that a "no-slap down" safety function is maintained for loading conditions associated with a BDBGM seismic event. This requirement applies to the DTF trolleys, pedestals, and hold-down devices. Supports Functions 2.1.4 and 2.1.5.

Basis: This safety requirement is identified in Nuclear Safety Design Bases for License Application (BSC 2005 [DIRS 171512], Table A-II).

3.1.1.1.21 Requirement: Loaded transfer trolleys shall not derail or drop their loads. This requirement applies to the DTF trolleys, pedestals, and hold-down devices. Supports Functions 2.1.4 and 2.1.5.

Basis: This safety requirement is identified in Nuclear Safety Design Bases for License Application (BSC 2005 [DIRS 171512], Table A-II).

3.1.1.1.22 Requirement: Upon a loss of power, the spent fuel transfer machine shall be designed to stop, retain its load, and enter a locked mode; upon a restoration of power, the machine shall stay in the locked mode until operator action is taken. This requirement applies to the DTF spent fuel transfer machine and FHF spent fuel transfer machine. Supports Functions 2.1.4 and 2.1.5.

Basis: This safety requirement is identified in Nuclear Safety Design Bases for License Application (BSC 2005 [DIRS 171512], Table A-II).

3.1.1.1.23 Requirement: Crane lifting yokes shall be designed for loading conditions associated with a DBGM-2 seismic event. In addition, an analysis shall demonstrate that the crane lifting yokes have sufficient seismic design margin to ensure that a "no drop" safety function is maintained for loading conditions associated with a BDBGM seismic event. This requirement applies to the DTF waste package loadout handling crane lifting yokes and DTF navy canister handling crane lifting yokes. Supports Function 2.1.4 and 2.1.5.

Basis: This safety requirement is identified in Nuclear Safety Design Bases for License Application (BSC 2005 [DIRS 171512], Table A-II).

3.1.1.1.24 Requirement: Pedestals and hold-down devices shall be designed for loading conditions associated with a DBGM-2 seismic event. In addition, an analysis shall demonstrate that the pedestals and hold-down devices have sufficient seismic design margin to ensure that a "no tipover" safety function is maintained for loading conditions associated with a BDBGM seismic event. This requirement applies to the DTF trolleys, pedestals, and hold-down devices. Supports Functions 2.1.4 and 2.1.5.

Basis: This safety requirement is identified in Nuclear Safety Design Bases for License Application (BSC 2005 [DIRS 171512], Table A-II).

3.1.1.1.25 Requirement: In the event of a credible fire in an area where waste forms are present, the temperature of the machinery that handles or transports SNF/HLW shall not reach a 
level that would make it drop its load. This requirement applies to the DTF trolleys, pedestals, and hold-down devices. Supports Functions 2.1.4 and 2.1.5.

Basis: This safety requirement is identified in Nuclear Safety Design Bases for License Application (BSC 2005 [DIRS 171512], Table A-II).

3.1.1.1.26 Requirement: The spent fuel transfer machine shall have a drop rate of less than $1 \times 10^{-5}$ drops/transfer, including transfers in single-assembly canisters. This requirement applies to the DTF spent fuel transfer machine and FHF spent fuel transfer machine. Supports Functions 2.1.4 and 2.1.5.

Basis: This safety requirement is identified in Nuclear Safety Design Bases for License Application (BSC 2005 [DIRS 171512], Table A-II).

3.1.1.1.27 Requirement: The spent fuel transfer machine and grapples shall be designed for loading conditions associated with a DBGM-1 seismic event to demonstrate sufficient seismic margin to ensure that a "maintain waste form" safety function is maintained. This requirement applies to the DTF spent fuel transfer machine and FHF spent fuel transfer machine. Supports Functions 2.1.4 and 2.1.5.

Basis: This safety requirement is identified in Nuclear Safety Design Bases for License Application (BSC 2005 [DIRS 171512], Table A-II).

3.1.1.1.28 Requirement: The rate of collisions during an assembly transfer operation shall be less than or equal to $1 \times 10^{-5}$ collisions/transfer. This requirement applies to the DTF spent fuel transfer machine and FHF spent fuel transfer machine. Supports Functions 2.1.2 and 2.1.5.

Basis: This safety requirement is identified in Nuclear Safety Design Bases for License Application (BSC 2005 [DIRS 171512], Table A-II).

3.1.1.1.29 Requirement: The probability of a drop of handling equipment onto a commercial SNF assembly with enough energy to breach the assembly shall be less than $1 \times 10^{-7}$ impacts/transfer for each assembly transferred. This requirement applies to the DTF spent fuel transfer machine and FHF spent fuel transfer machine. Supports Functions 2.1.2 and 2.1.5.

Basis: This safety requirement is identified in Nuclear Safety Design Bases for License Application (BSC 2005 [DIRS 171512], Table A-II).

3.1.1.1.30 Requirement: The spent fuel transfer machine shall not be capable of lateral movements of handling equipment at a speed that could initiate an event sequence as a result of a collision with a SNF assembly. This requirement applies to the DTF spent fuel transfer machine and FHF spent fuel transfer machine. Supports Functions 2.1.2 and 2.1.5.

Basis: This safety requirement is identified in Nuclear Safety Design Bases for License Application (BSC 2005 [DIRS 171512], Table A-II).

3.1.1.1.31 Requirement: In the event of a credible fire in an area where waste forms are present, the temperature of the machinery that handles or transports SNF/HLW shall not reach a level that would make it drop its load. This requirement applies to the DTF spent fuel transfer machine and FHF spent fuel transfer machine. Supports Functions 2.1.4 and 2.1.5. 
Basis: This safety requirement is identified in Nuclear Safety Design Bases for License Application (BSC 2005 [DIRS 171512], Table A-II).

3.1.1.1.32 Requirement: A drop of a load from machinery that handles SNF due to a spurious signal caused by a fire shall have a probability of less than $1 \times 10^{-4}$ over the life of the facility. This requirement applies to the DTF spent fuel transfer machine and FHF spent fuel transfer machine. Supports Functions 2.1.4 and 2.1.5.

Basis: This safety requirement is identified in Nuclear Safety Design Bases for License Application (BSC 2005 [DIRS 171512], Table A-II).

3.1.1.1.33 Requirement: The waste package tilting machine shall include measures to prevent movement or release of the lock on waste package trunnions while the waste package is being lowered onto the emplacement pallet. This requirement applies to the DTF waste package tilting machine, CHF waste package tilting machine, and FHF waste package tilting machine. Supports Function 2.1.5.

Basis: This safety requirement is identified in Nuclear Safety Design Bases for License Application (BSC 2005 [DIRS 171512], Table A-II).

3.1.1.1.34 Requirement: The waste package tilting machine system shall be designed for loading conditions associated with a DBGM-2 seismic event to maintain stability and prevent a waste package drop or slapdown. In addition, an analysis shall demonstrate that the waste package tilting machine system has sufficient seismic design margin to ensure that "no drop" and "no slapdown" safety functions are maintained for loading conditions associated with a BDBGM seismic event. This requirement applies to the DTF waste package tilting machine, CHF waste package tilting machine, and FHF waste package tilting machine. Supports Functions 2.1.4 and 2.1.5.

Basis: This safety requirement is identified in Nuclear Safety Design Bases for License Application (BSC 2005 [DIRS 171512], Table A-II).

3.1.1.1.35 Requirement: The waste package tilting machine shall be designed to prevent backwards slap downs. This requirement applies to the DTF waste package tilting machine, CHF waste package tilting machine, and FHF waste package tilting machine. Supports Functions 2.1.4 and 2.1.5.

Basis: This safety requirement is identified in Nuclear Safety Design Bases for License Application (BSC 2005 [DIRS 171512], Table A-II).

3.1.1.1.36 Requirement: An impact or collision between the waste package tilting machine and a waste package shall not breach the waste package or cause it to fall off the emplacement pallet. This requirement applies to the DTF waste package tilting machine, CHF waste package tilting machine, and FHF waste package tilting machine. Supports Functions 2.1.4 and 2.1.5.

Basis: This safety requirement is identified in Nuclear Safety Design Bases for License Application (BSC 2005 [DIRS 171512], Table A-II).

3.1.1.1.37 Requirement: The premature actuation of the waste package turntable (while holding the waste package on an emplacement pallet) before the disengagement of the trunnion 
collar removal machine shall be precluded. This requirement applies to the DTF waste package turntable, CHF waste package turntable, and FHF waste package turntable. Supports Function 2.1.5.

Basis: This safety requirement is identified in Nuclear Safety Design Bases for License Application (BSC 2005 [DIRS 171512], Table A-II).

3.1.1.1.38 Requirement: An impact or collision between the waste package turntable and a waste package shall not breach the waste package or cause it to fall off the emplacement pallet. This requirement applies to the DTF waste package turntable, CHF waste package turntable, and FHF waste package turntable. Supports Function 2.1.5.

Basis: This safety requirement is identified in Nuclear Safety Design Bases for License Application (BSC 2005 [DIRS 171512], Table A-II).

3.1.1.1.39 Requirement: The waste package turntable system shall be designed for loading conditions associated with a DBGM-2 seismic event to maintain turntable stability and prevent waste package tipover. In addition, an analysis shall demonstrate that the waste package turntable system has sufficient seismic design margin to ensure that a "no tipover" safety function is maintained for loading conditions associated with a BDBGM seismic event. This requirement applies to the DTF waste package turntable, CHF waste package turntable, and FHF waste package turntable. Supports Functions 2.1.4 and 2.1.5.

Basis: This safety requirement is identified in Nuclear Safety Design Bases for License Application (BSC 2005 [DIRS 171512], Table A-II).

3.1.1.1.40 Requirement: The premature actuation of the waste package turntable (while holding the waste package on an emplacement pallet) before the disengagement of the trunnion collar removal machine shall be precluded. This requirement applies to the DTF trunnion collar removal machine, CHF trunnion collar removal machine, and FHF trunnion collar removal machine. Supports Functions 2.1.4 and 2.1.5.

Basis: This safety requirement is identified in Nuclear Safety Design Bases for License Application (BSC 2005 [DIRS 171512], Table A-II).

3.1.1.1.41 Requirement: The trunnion collar removal machine system shall be designed for loading conditions associated with a DBGM-2 seismic event to prevent slapdown of the waste package. In addition, an analysis shall demonstrate that the trunnion collar removal machine system has sufficient seismic design margin to ensure that "no slapdown" and "no breach" safety functions are maintained for loading conditions associated with a BDBGM seismic event. This requirement applies to the DTF trunnion collar removal machine, CHF trunnion collar removal machine, and FHF trunnion collar removal machine. Supports Functions 2.1.4 and 2.1.5.

Basis: This safety requirement is identified in Nuclear Safety Design Bases for License Application (BSC 2005 [DIRS 171512], Table A-II).

3.1.1.1.42 Requirement: An impact or collision between the trunnion collar removal machine and a waste package shall not breach the waste package or cause it to fall off the emplacement pallet. This requirement applies to the DTF trunnion collar removal machine, CHF trunnion 
collar removal machine, and FHF trunnion collar removal machine. Supports Functions 2.1.4 and 2.1.5.

Basis: This safety requirement is identified in Nuclear Safety Design Bases for License Application (BSC 2005 [DIRS 171512], Table A-II).

3.1.1.1.43 Requirement: Criticality safety shall be ensured for the commercial SNF assembly staging racks loaded to capacity with the most reactive commercial SNF assembly accepted at the repository with moderator control in effect. This requirement applies to the DTF canister and SNF staging racks. Supports Functions 2.1.4 and 2.1.5.

Basis: This safety requirement is identified in Nuclear Safety Design Bases for License Application (BSC 2005 [DIRS 171512], Table A-II).

3.1.1.1.44 Requirement: The most reactive configuration of standardized DOE SNF canisters shall be capable of being loaded into canister staging racks (with credit for moderator control) without leading to a nuclear a criticality. This requirement applies to the DTF canister and SNF staging racks and CHF canister staging racks. Supports Functions 2.1.4 and 2.1.5.

Basis: This safety requirement is identified in Nuclear Safety Design Bases for License Application (BSC 2005 [DIRS 171512], Table A-II).

3.1.1.1.45 Requirement: Criticality safety shall be ensured for commercial SNF assemblies dropped into or onto a commercial SNF assembly staging rack with moderator control in effect. This requirement applies to the DTF canister and SNF staging racks. Supports Functions 2.1.4 and 2.1.5.

Basis: This safety requirement is identified in the Nuclear Safety Design Bases for License Application (BSC 2005 [DIRS 171512], Table A-II).

3.1.1.1.46 Requirement: The canister and SNF staging racks shall be designed for loading conditions associated with a DBGM-2 seismic event for stability and distortion such as to maintain assembly/canister geometry in the rack. In addition, analyses shall demonstrate that the staging racks have sufficient seismic design margin to ensure that distortion of the racks is limited and stability is maintained for loading conditions associated with a BDBGM seismic event. This requirement applies to the DTF canister and SNF staging racks. Supports Functions 2.1.4 and 2.1.5.

Basis: This safety requirement is identified in Nuclear Safety Design Bases for License Application (BSC 2005 [DIRS 171512], Table A-II).

3.1.1.1.47 Requirement: The staging racks shall be designed for loading conditions associated with a DBGM-2 seismic event for stability and distortion such as to maintain canister geometry in the rack. In addition, analyses shall demonstrate that the staging racks have sufficient seismic design margin to ensure that distortion of the racks is limited and stability is maintained for loading conditions associated with a BDBGM seismic event. This requirement applies to the CHF canister staging racks. Supports Functions 2.1.4 and 2.1.5.

Basis: This safety requirement is identified in Nuclear Safety Design Bases for License Application (BSC 2005 [DIRS 171512], Table A-II). 
3.1.1.1.48 Requirement: The spent fuel transfer machine and anchorages shall be designed to prevent collapse of this system for loading conditions associated with a DBGM-2 seismic event. In addition, an analysis shall demonstrate that the spent fuel transfer machine and anchorages have sufficient seismic design margin to ensure that a "no fall down" safety function is maintained for loading conditions associated with a BDBGM seismic event. This requirement applies to the DTF spent fuel transfer machine and FHF spent fuel transfer machine. Supports Functions 2.1.4 and 2.1.5.

Basis: This safety requirement is identified in Nuclear Safety Design Bases for License Application (BSC 2005 [DIRS 171512], Table A-II).3.1.1.1.49 Requirement: The design of the DPC cutting machine shall ensure that the DPC lid will prevent damage to the SNF assembly resulting in radiological release should the cutting machine fall into or make contact with the DPC. This requirement applies to the DTF DPC cutting machine. Supports Functions 2.1.4 and 2.1.5.

Basis: This safety requirement is identified in Nuclear Safety Design Bases for License Application (BSC 2005 [DIRS 171512], Table A-II).

3.1.1.1.50 Requirement: The DPC cutting machine shall preclude a radiological release due to damage inflicted upon the DPC contents during the cutting process. This requirement applies to the DTF DPC cutting machine. Supports Functions 2.1.4 and 2.1.5.

Basis: This safety requirement is identified in Nuclear Safety Design Bases for License Application (BSC 2005 [DIRS 171512], Table A-II).

3.1.1.1.51 Requirement: The DPC cutting machine shall be designed for loading conditions associated with a DBGM-2 seismic event and to demonstrate sufficient seismic design margin to ensure that "no failure" and "no fall down" safety functions are maintained for loading conditions associated with a BDBGM seismic event. This requirement applies to the DTF DPC cutting machine. Supports Functions 2.1.4 and 2.1.5.

Basis: This safety requirement is identified in Nuclear Safety Design Bases for License Application (BSC 2005 [DIRS 171512], Table A-II).3.1.1.1.52 Requirement: A drop or collision involving components associated with a docking port shall not breach the lid of a transportation cask or site-specific cask situated at the docking port. This requirement applies to the DPC docking station, DTF cask/WP docking stations, and FHF cask/WP docking stations. Supports Functions 2.1.4 and 2.1.5.

Basis: This safety requirement is identified in Nuclear Safety Design Bases for License Application (BSC 2005 [DIRS 171512], Table A-II).

\subsubsection{Environmental Requirements}

Specific environmental requirements for the SNF/HLW transfer system have not been identified at this stage of the design. Environmental requirements for addressing land disturbance from construction, waste minimization, water use or pollution prevention requirements may be needed and will be added to the SNF/HLW transfer system description document when these requirements are developed. See Section 3.2.7 for additional environmental protection program requirements. 


\subsubsection{Mission-Critical Requirements}

3.1.1.3.1 Requirement: Mechanical handling systems shall have an operational life of 50 years. Mechanical handling equipment shall satisfy this criterion directly or be maintainable or easily replaced over the system lifetime. Supports Functions 2.1.1, 2.1.2, and 2.1.3.

Basis: The specification of a system operational lifetime is required to assure that the system can fulfill system functions. [PDC 4.7.1.2-1]

3.1.1.3.2 Requirement: The system shall be designed to meet a throughput of 3000 metric tons heavy metal of commercial SNF per year. This requirement supports Functions 2.1.1, 2.1.2, and 2.1.3.

Basis: This requirement is based on the site mission. [F\&OR, Appendix A]

Comment: This requirement is based upon the assumption that all commercial SNF will be processed in the DTF. This assumption takes no credit for commercial SNF processing in FHF (FHF throughput is TBD). Current plans for CHF is to process canistered waste only. Any canistered commercial SNF may be processed in CHF by placing the DPCs into site-specific casks and moving them to an aging pad. Canistered commercial SNF placed on the aging pad will eventually be processed through DTF. The maximum annual commercial SNF throughput requirement for the repository is 3000 metric tons heavy metal per year (Curry 2004 [DIRS 170557], Appendix A).

\subsubsection{General Requirements}

3.1.1.4.1 Requirement: The SNF/HLW transfer system shall provide means of detecting accident conditions. Supports Function 2.1.4.

Performance Acceptance Criterion: The SNF/HLW transfer system shall provide sufficient systems (e.g., instruments, equipment, alarms) to detect normal and off-normal operating conditions, including different levels of response.

Basis: To protect the SNF/HLW transfer system from accident conditions. [F\&OR 1.1.4.2-1]

3.1.1.4.2 Requirement: The SNF/HLW transfer system shall be able to retrieve fully loaded trolleys, should they fail to respond to normal operations. Supports Function 2.1.4.

Performance Acceptance Criterion: The design of the trolleys shall allow for retrieval in situations of:

1. Derailment

2. Wheel/drive failure

3. Loss of power

4. Similar foreseeable occurrences

Basis: To allow the SNF/HLW transfer system to recover from off-normal events. [F\&OR 1.1.4-4] 
3.1.1.4.3 Requirement: The SNF/HLW transfer system shall control SNF/HLW handling operations. Supports Function 2.1.5.

Performance Acceptance Criterion: The SNF/HLW transfer system shall control all aspects of SNF/HLW handling operations, including material and equipment movement, criticality, quality of sealing, radiological confinement, and nuclear material inventories.

Basis: To regulate SNF/HLW handling operations at the SNF/HLW transfer system. [F\&OR 1.1-6]

3.1.1.4.3.1 Requirement: The SNF/HLW transfer system shall control SNF/HLW movement. Supports Function 2.1.5.

Performance Acceptance Criterion: The SNF/HLW transfer system shall physically control the movement of SNF/HLW within the system boundary from one destination to another to assure safety of transfer and to avoid damage to the material, transfer cell, or equipment.

Basis: To assure safe movement of fissile material within the SNF/HLW transfer system. [F\&OR 1.1.6-1]

3.1.1.4.3.2 Requirement: The SNF/HLW transfer system shall control equipment movement components. Supports Function 2.1.5.

Performance Acceptance Criteria:

1. The SNF/HLW transfer system shall control functions of the mechanical handling equipment in order to keep boundaries of movement, set by the order of events, sizes of the equipment and pieces handled, safety, and drop height limits for the equipment handled.

2. Maintain positive control and feedback of material movement.

Basis: To establish control of functions of equipment movement components. [F\&OR 1.1.6-2]

3.1.1.4.3.3 Requirement: The SNF/HLW transfer system shall control mechanical handling operations. Supports Function 2.1.5.

Performance Acceptance Criterion: The SNF/HLW transfer system shall provide redundant control capabilities for each cell to allow human oversight and control of material handling operations.

Basis: To provide safe control of material handling operations. [F\&OR 1.1.6-3]

3.1.1.4.4 Requirement: The SNF/HLW transfer system shall provide a visual means of observing operations. Supports Function 2.1.5.

Performance Acceptance Criterion: Video communications shall be provided within the system to monitor and assist with surface facilities operations.

Basis: To conduct safe operations at the SNF/HLW transfer system. [F\&OR 1.4.1.2.8-1] 
3.1.1.4.5 Requirement: The SNF/HLW transfer system shall protect casks, site-specific casks and waste packages. Supports Function 2.1.2.

Performance Acceptance Criterion: Transportation casks, site-specific casks, and waste packages shall be protected from hazards such as exterior contamination from transfer operations, damage to cask and waste package body and sealing surfaces, debris on sealing surfaces, drops, and Category 1 and 2 event sequences defined by Preclosure Safety Analysis.

Basis: To protect the cask and waste packages from damage and contamination. [F\&OR 1.1.2.2-1]

3.1.1.4.6 Requirement: Upon a loss of power, the FHF fuel transfer maintenance crane shall be designed to stop, retain is load, and enter a locked mode; upon restoration of power, the crane shall stay in the locked mode until operator action is taken. Supports Functions 2.1.4 and 2.1.5.

Basis: This requirement is derived to support the safety requirement identified in Nuclear Safety Design Basis for License Application (BSC 2005 [DIRS 171512]) document for similar equipment.

3.1.1.4.7 Requirement: The FHF fuel transfer maintenance crane and grapples shall be designed for loading conditions associated with a DBGM-1 seismic event to demonstrate sufficient seismic design margin to ensure that a "maintain waste form" safety function is maintained. Supports Functions 2.1.4 and 2.1.5.

Basis: This requirement is derived to support the safety requirement identified in Nuclear Safety Design Basis for License Application (BSC 2005 [DIRS 171512]) document for similar equipment.

3.1.1.4.8 Requirement: The FHF fuel transfer maintenance crane and anchorages shall be designed to prevent collapse of this system for loading conditions associated with a DBGM-2 seismic event. In addition, an analysis shall demonstrate that the fuel transfer maintenance crane and anchorages have sufficient seismic design margin to ensure that a "no fall down" safety function is maintained for loading conditions associated with a BDBGM seismic event. Supports Functions 2.1.4 and 2.1.5.

Basis: This requirement is derived to support the safety requirement identified in Nuclear Safety Design Basis for License Application (BSC 2005 [DIRS 171512]) document for similar equipment.

3.1.1.4.9 Requirement: The FHF fuel transfer maintenance crane shall have a drop rate of less than (to be defined in future revision of NSDB SNF/HLW transfer system) drops/transfer. Supports Functions 2.1.4 and 2.1.5.

Basis: This requirement is derived to support the safety requirement identified in Nuclear Safety Design Basis for License Application (BSC 2005 [DIRS 171512]) document for similar equipment.

3.1.1.4.10 Requirement: In the event of a credible fire in an area where waste forms are present, the temperature of the FHF fuel transfer maintenance crane shall be designed to remain structurally intact and shall have no load drop due to the maximum credible fire. Supports Functions 2.1.4 and 2.1.5.

Basis: This requirement is derived to support the safety requirement identified in the Nuclear Safety Design Basis for License Application (BSC 2005 [DIRS 171512]) document for similar equipment. 
3.1.1.4.11 Requirement: The FHF fuel transfer maintenance crane shall not be capable of lateral movements of handling equipment at a speed that could initiate an event sequence as a result of a collision with a SNF assembly. Supports Functions 2.1.4 and 2.1.5.

Basis: This requirement is derived to support the safety requirement identified in Nuclear Safety Design Basis for License Application (BSC 2005 [DIRS 171512]) document for similar equipment.

\subsubsection{Subsystems and Major Components}

\subsubsection{Dual-Purpose Canister Cutting Subsystem}

3.1.2.1.1 Requirement: The SNF/HLW transfer system shall handle non-disposable canisters such as DPCs. Supports Function 2.1.2.

Performance Acceptance Criterion: DPCs shall be removed from the transportation cask or site-specific cask and placed in the DPC cutting cell to access the contents.

Basis: To access the contents of DPCs. [F\&OR 1.1.2.2-4]

3.1.2.1.2 Requirement: The SNF/HLW transfer system shall prepare unloaded DPC shells and internals for transfer to the low-level waste management system for offsite disposal. Supports Function 2.1.2.

Performance Acceptance Criterion: The SNF/HLW transfer system shall be capable of transferring DPC shell and lids to an overpack for transport to disposal.

Basis: To assure proper disposal of DPC shells and its internals. [F\&OR 1.1.2.2-10]

3.1.2.1.3 Requirement: The SNF/HLW transfer system shall facilitate access to the DPC sampling port. Supports Function 2.1.1.

Performance Acceptance Criterion: The DPC outer lid and port covers shall be removed, to allow for sampling.

Basis: Necessary to determine condition of DPC contents. [F\&OR 1.1.2.1.4-1]

3.1.2.1.4 Requirement: The SNF/HLW transfer system shall sample the atmosphere inside the DPC. Supports Function 2.1.1.

Performance Acceptance Criterion: The inside of the DPC shall be sampled for gases that may indicate hazardous conditions, such as flammable or explosive gas mixtures and fission products.

Basis: Necessary to determine condition of DPC contents. [F\&OR 1.1.2.1.4-2]

3.1.2.1.5 Requirement: The SNF/HLW transfer system shall vent the inside of the DPC. Supports Function 2.1.1. 


\section{Performance Acceptance Criteria:}

1. The DPC shall be vented to achieve atmospheric pressure.

2. If combustible gases are present in the sample, the DPC shall be purged with nitrogen or other inert gas until samples show a level below $25 \%$ of the lower explosive limit.

Basis: Necessary to safely open DPC. [F\&OR 1.1.2.1.4-3]

3.1.2.1.6 Requirement: The SNF/HLW transfer system shall enable access to the inside of the DPC. Supports Function 2.1.1.

Performance Acceptance Criterion: The DPC inner lid and shield plug shall be removed within 24 (operational constraint) hours of venting.

Basis: Prevent build-up of flammable gases. [F\&OR 1.1.2.1.4-4]

\subsubsection{Dry Transfer Subsystem}

3.1.2.2.1 Requirement: The SNF/HLW transfer system shall verify integrity of lid-seating areas. Supports Function 2.1.2.

\section{Performance Acceptance Criteria:}

1. Inspection shall be performed on waste packages to confirm that the lid seating surface of the waste package is undamaged and free of debris.

2. In the event of debris on the lid seating surfaces, remotely remove debris to clear seating surface.

Basis: To establish a tight seal on waste packages. [F\&OR 1.1.2.2-6]

3.1.2.2.2 Requirement: The SNF/HLW transfer system shall provide contamination control in waste package closure and staging areas. Supports Function 2.1.2.

\section{Performance Acceptance Criteria:}

1. The inner lid shall be placed on the waste package and restrained while it is still docked to the transfer area to prevent spread of contamination from inside the waste package.

2. Provide engineering controls to minimize the spread of contamination from the waste package lid area during movement to the staging and closure area.

3. The SNF/HLW transfer system shall provide the capability to survey the waste package for removable radiological contamination by obtaining a radiological smear of a vulnerable area on the lid and lid-waste package interface areas. Decontamination will be provided as required to meet the radiological limits as established.

Basis: To minimize the spread of contamination. [F\&OR 1.1.2.2-7] 
Comment: Currently, the performance acceptance criteria above are not part of the system design, although it may be required to mitigate the spread of waste package contamination. Determination for the amount of waste package contamination that may be present and the equipment to detect it is under development.

3.1.2.2.3 Requirement: The SNF/HLW transfer system shall support achieving confinement of the transportation cask with the transfer area when transferring commercial bare SNF. Supports Function 2.1.1.

Performance Acceptance Criterion: The SNF/HLW transfer system shall dock the transportation cask with the transfer area to confine radiological hazards, with positive, instrumented indication of confinement being achieved.

Basis: To establish confinement prior to SNF/HLW transfer. [F\&OR 1.1.2.1.1-7]

3.1.2.2.4 Requirement: The SNF/HLW transfer system shall support establishing confinement of the waste package within the transfer area. Supports Function 2.1.1.

Performance Acceptance Criterion: The SNF/HLW transfer system shall dock the waste package with the transfer area to confine the interior of the waste package, with positive, instrumented indication of confinement being achieved.

Basis: To establish confinement prior to SNF/HLW transfer. [F\&OR 1.1.2.1.2-4]

3.1.2.2.5 Requirement: The SNF/HLW transfer system shall support establishing confinement of the site-specific cask within the transfer area. Supports Function 2.1.1.

Performance Acceptance Criterion: The SNF/HLW transfer system shall dock the site-specific cask with the waste transfer cell to confine the interior of the site-specific cask, with positive, instrumented indication of confinement being achieved.

Basis: To establish confinement prior to SNF/HLW transfer. [F\&OR 1.1.2.1.3-4]

3.1.2.2.6 Requirement: The SNF/HLW transfer system shall support establishing confinement to support transfer from DPC. Supports Function 2.1.1.

Performance Acceptance Criterion: The DPC is open to the waste transfer cell; confinement is established by the waste transfer cell and the DPC cutting/WP dry remediation cell. This function is part of the DPC cutting subsystem and only applies to the DTF.

Basis: Establish confinement prior to transfer. [F\&OR 1.1.2.1.4-5]

3.1.2.2.7 Requirement: The SNF/HLW transfer system shall prepare transfer equipment. Supports Function 2.1.2.

Performance Acceptance Criterion: The SNF/HLW transfer system shall be capable of preparing all appropriate equipment necessary for transfer of SNF/HLW and ensuring working conditions prior to opening casks or waste packages. 
Basis: To assure safe transfer operations with proper equipment and working conditions. [F\&OR 1.1.2.2-3]

3.1.2.2.8 Requirement: The $\mathrm{SNF} / \mathrm{HLW}$ transfer system shall prepare waste package for sealing following loading. Supports Function 2.1.2.

Performance Acceptance Criterion: The SNF/HLW transfer system shall be capable of removing the waste package from the transfer area and placing it in the weld closure area.

Basis: To assure that the waste packages are properly sealed. [F\&OR 1.1.2.2-8]

3.1.2.2.9 Requirement: The SNF/HLW transfer system shall protect SNF/HLW from drops or impacts. Supports Function 2.1.2.

Performance Acceptance Criterion: SNF/HLW shall be protected from drops or impacts to prevent damage to fuel material and to assure that fuel and canisters remain suitable for placement in waste packages.

Basis: Ensure that emplacement materials are not damaged prior to final waste package loading. [F\&OR 1.1.2.2-9]

3.1.2.2.10 Requirement: The SNF/HLW transfer system shall conduct transfers. Supports Function 2.1.2.

Performance Acceptance Criterion: The SNF/HLW shall be removed from casks, site-specific casks, DPCs and placed in the waste package or site-specific casks.

Basis: To safely transfer. [F\&OR 1.1.2.2-5]

3.1.2.2.10.1 Requirement: The SNF/HLW transfer system shall identify SNF/HLW elements/canisters. Supports Function 2.1.2.

Performance Acceptance Criterion: The SNF/HLW transfer system shall allow viewing to identify and record the location of SNF/HLW elements/canisters being removed from the casks, DPCs, or waste packages.

Basis: To verify the identity and location of elements/canisters removed. [F\&OR 1.1.2.2.5-1]

3.1.2.10.2 Requirement: The SNF/HLW transfer system shall verify individual SNF/HLW elements/canisters. Supports Function 2.1.2.

Performance Acceptance Criterion: The SNF/HLW transfer system shall provide the means to compare the identification number of the elements being removed with those in the shipping manifest or SNF aging record for site-specific casks.

Basis: To compare the identity of the elements at the point of origin to those being removed from the cask. [F\&OR 1.1.2.2.5-2]

3.1.2.10.3 Requirement: The SNF/HLW transfer system shall transfer individual SNF/HLW elements/canisters. Supports Function 2.1.2. 
Performance Acceptance Criterion: The SNF/HLW transfer system shall be capable of placing bare fuel elements or canisters removed from the cask or opened DPC into a predetermined location in a staging area, waste package, or site-specific cask.

Basis: To conduct safe transfer of elements/canisters. [F\&OR 1.1.2.2.5-3]

3.1.2.2.10.4 Requirement: The design of the SNF/HLW transfer system shall not exclude the ability to add burn up measurement equipment for SNF assemblies. Supports Function 2.1.

Performance Acceptance Criterion: The location of the burn up measurement equipment, if installed, shall be compatible with transfer operations.

Basis: To provide an area for conducting burn up measurements, if needed in the future. [F\&OR 1.1.2.2.5-4]

3.1.2.2.11 Requirement: The SNF/HLW transfer system shall be able to move SNF/HLW into and out of the staging area within the transfer cell. Supports Function 2.1.2.

Basis: To establish a staging area for SNF/HLW. [F\&OR 1.1.2.2-2]

\subsubsection{Waste Package Loadout Subsystem}

3.1.2.3.1 Requirement: The SNF/HLW transfer system shall survey/inspect sealed waste package to assure it is suitable for emplacement. Supports Function 2.1.3.

\section{Performance Acceptance Criteria:}

1. The SNF/HLW transfer system shall provide the capability to survey the waste package for removable radiological contamination by obtaining a radiological smear of a vulnerable area. Decontamination will be provided as required to meet the radiological limits as established.

2. Inspection shall be performed on sealed waste packages for physical damage to corrosion barrier.

Basis: Waste package must be suitable for emplacement. [F\&OR 1.1.3-1]

Comment: The waste package inspection, survey, and decontamination functions relating to the SNF/HLW transfer system are currently under development.

3.1.2.3.2 Requirement: The SNF/HLW transfer system shall receive waste package from the waste package closure cell. Supports Function 2.1.3.

Performance Acceptance Criterion: The SNF/HLW transfer system shall provide adequate equipment and processes to receive sealed waste packages, stage waste packages, and prepare for transfer to waste package transporter.

Basis: Identify space for preparation for emplacement. [F\&OR 1.1.3-2]

3.1.2.3.3 Requirement: The SNF/HLW transfer system shall remove handling components. Supports Function 2.1.3. 
Performance Acceptance Criterion: The SNF/HLW transfer system shall remove ancillary components for reuse and avoid impacts to long term performance of the waste package.

Basis: Ancillary components are to be removed prior to waste package emplacement. [F\&OR 1.1.3-3]

3.1.2.3.4 Requirement: The SNF/HLW transfer system shall verify the waste package identification. Supports Function 2.1.3.

Performance Acceptance Criterion: The SNF/HLW transfer system shall provide the means to confirm the identity of and record the waste package to be emplaced.

Basis: Records verification. [F\&OR 1.1.3-4]

3.1.2.3.5 Requirement: The SNF/HLW transfer system shall orient the waste package consistent with drift configuration. Supports Function 2.1.3.

Performance Acceptance Criterion: The SNF/HLW transfer system shall be capable of rotating the waste package to a horizontal position.

Basis: Prevent positioning/handling within drift. [F\&OR 1.1.3-5]

3.1.2.3.6 Requirement: The SNF/HLW transfer system shall place the waste package on an emplacement pallet and transfer the loaded pallet to the waste package transporter. Supports Function 2.1.3.

Performance Acceptance Criterion: The SNF/HLW transfer system shall place the waste package on the emplacement pallet onto the waste package transporter.

Basis: Corresponds with design and operation of waste package transporter. [F\&OR 1.1.3-6]

3.1.2.3.7 Requirement: The SNF/HLW transfer system shall enable receipt of retrieved waste packages. Supports Function 2.1.3.

Performance Acceptance Criterion: Equipment and processes shall be available for receipt of retrieved waste packages from the emplacement drift during the preclosure phase of repository operations.

Basis: Retrieval of emplaced waste packages. [F\&OR 1.1.3-11]

\subsubsection{Boundaries and Interfaces}

Specific requirements for system boundaries or interfaces have not been identified at this stage of design. The boundaries and interfaces listed in Tables 4-1, 4-2, and 4-3 will be converted to requirements and performance acceptance criteria in a future revision of this SDD. Additionally, the listed interface functions will be checked to ensure that adequate detail is provided. 
Boundaries and interfaces for the SNF/HLW transfer system are discussed in Section 4.

- Boundaries and interfaces for the DTF are discussed in Section 4.1.2.1.

- Boundaries and interfaces for the CHF are discussed in Section 4.1.2.2.

- Boundaries and interfaces for the FHF are discussed in Section 4.1.2.3.

\subsubsection{Communications System}

The communications system requirements for the SNF/HLW transfer system are identified in the communications system design documentation.

The SNF/HLW transfer system requires video monitoring of the areas that are covered by the communications system. The communications system provides telephone, radio, and public address support for normal and off-normal operations and events.. Emergency announcements to plant personnel will be over the public address system. As the design progresses and operational details are defined, the SNF/HLW transfer system requirements imposed on the communications system will be further delineated.

\subsubsection{Facilities}

The facilities requirements for the SNF/HLW transfer system are identified in the individual facility design documentation.

The SNF/HLW transfer system equipment and components are located in the DTF, CHF, and FHF. As the design progresses and operational details are defined, the SNF/HLW transfer system requirements imposed on the facilities will be further delineated.

\subsubsection{Radiation/Radiological Monitoring System}

The radiation/radiological monitoring system requirements for the SNF/HLW transfer system are identified in the radiation/radiological monitoring system design documentation.

Area radiation monitors, continuous air monitors, stack monitors, and criticality monitors are used to support the SNF/HLW transfer system, as necessary. As the design progresses and operational details are defined, the SNF/HLW transfer system requirements imposed on the radiation/radiological monitoring system will be further delineated.

\subsubsection{Digital Control and Management Information System}

The digital control and management information system requirements for the SNF/HLW transfer system are identified in the digital control and management information system design documentation.

The SNF/HLW transfer system interfaces with the digital control and management information system by providing information such as the location of casks, site-specific casks, waste packages, SNF/HLW, and status of equipment. 
The SNF/HLW Transfer System will have safety functions performed by and indications and alarms provided by dedicated safety related control system. The DCMIS will interface with and receive information from the safety related controls, but will be isolated from these systems such that the DCMIS shall not be capable of overriding the safety functions. Normal process functions will be available locally in a non-safety related control system, which also cannot override the safety functions.

As the design progresses and operational details are defined, the SNF/HLW transfer system requirements imposed on the digital control and management information system will be further delineated.

\subsubsection{Low-Level Radioactive Waste Management System}

The low-level radioactive waste management system requirements for the SNF/HLW transfer system are identified in the low-level radioactive waste management system design documentation.

The SNF/HLW transfer system interfaces with the low-level radioactive waste management system that is governed by the waste processing design criteria. As the design progresses and operational details are defined, the SNF/HLW transfer system requirements imposed on the lowlevel radioactive waste management system will be further delineated.

\subsubsection{Plant Services System}

The plant services system requirements for the SNF/HLW transfer system are identified in the plant services system design documentation.

As the design progresses and operational details are defined, the SNF/HLW transfer system requirements imposed on the plant services system will be further delineated.

\subsubsection{Electrical Power System}

The electrical power system requirements for the SNF/HLW transfer system are identified in the electrical power system design documentation.

As the design progresses and operational details are defined, the SNF/HLW transfer system requirements imposed on the electric power system will be further delineated.

\subsubsection{Fire Protection System}

The fire protection system requirements for the SNF/HLW transfer system are identified in the fire protection system design documentation.

As the design progresses and operational details are defined, the SNF/HLW transfer system requirements imposed on the fire protection system will be further delineated. 


\subsubsection{Safeguards and Security System}

The safeguards and security system requirements for the SNF/HLW transfer system are identified in the safeguards and security system design documentation.

As the design progresses and operational details are defined, the SNF/HLW transfer system requirements imposed on the safeguards and security system will be further delineated.

\subsubsection{Surface Heating, Ventilation, and Air-Conditioning System}

The surface nuclear HVAC and surface industrial HVAC systems requirements for the $\mathrm{SNF} / \mathrm{HLW}$ transfer system are identified in the surface HVAC systems design documentation.

As the design progresses and operational details are defined, the SNF/HLW transfer system requirements imposed on the surface HVAC system will be further delineated.

\subsubsection{Codes, Standards, and Regulations}

Design requirements and codes and standards for mechanical handling systems, including those of the SNF/HLW transfer system, are delineated in PDC 4.7.1.1 (BSC 2004 [DIRS 171599]) for mechanical handling systems and are discussed in these requirements.

\subsubsection{Operability}

This section will provide the operability requirements for the system. This will include technical specification requirements, if applicable, and other operating requirements from modes and conditions such as startup, normal operations, shutdown, emergency operation, and other system operations.

\subsection{SPECIAL REQUIREMENTS AND BASES}

All scenarios relating to the SNF/HLW transfer system presented in Preliminary Hazards Analysis for License Application Study (BSC 2004 [DIRS 167313]) have been screened for applicability. Existing design requirements have been found to capture all necessary requirements for mitigation control of applicable scenarios.

\subsubsection{Radiation and Other Hazards}

Contamination control is provided by cell walls and ventilation systems. Radiation shine is minimized by casks, canisters and the shielding provided by tools, platforms, and cell walls.

When detailed operational steps are developed, the radiation hazards will be identified and applicable design criteria and codes and standards will be applied.

The repository shall comply with the applicable provisions of 10 CFR 20, Standards for Protection Against Radiation [DIRS 173165]. The repository will involve handling and storage of radioactive materials as a U.S. Nuclear Regulatory Commission (NRC) licensed facility and as such, will be subject to 10 CFR 20 [DIRS 173165] regulations established for the control, 
receipt, possession, use, transfer, and disposition of radioactive materials by a licensee. Compliance with this regulation requires that the repository develop, document, and implement a comprehensive radiation protection program to assure that the individual and collective doses, as well as dose received by members of the public are maintained as low as is reasonably achievable (ALARA) and within the regulatory requirements.

3.2.1.1 Requirement: The SNF/HLW transfer system shall be designed and operated to minimize radiation exposures. Supports Functions 2.1.2, 2.1.4, and 2.1.5.

Performance Acceptance Criterion: The performance requirements for the SNF/HLW transfer system will be defined in subsequent designs to limit exposure to the operators and limit exposure to general workers.

Basis: The SNF/HLW transfer system shall limit radiation exposure to operators. Shielding may also be necessary to limit exposure to workers. [PRD-015/P015]

3.2.1.2 Requirement: The SNF/HLW transfer system shall be designed such that components can operate in and withstand the radiation environment in which they reside. Supports Functions 2.1.2, 2.1.4, and 2.1.5.

Performance Acceptance Criterion: The SNF/HLW transfer system components shall be designed to operate within the radiation environments depicted on the applicable facility radiation classification drawings.

Comment: Refer to BSC radiation classification drawings listed in Appendix B for the radiation environments in the DTF, CHF, and FHF.

Basis: This requirement is necessary to ensure proper equipment operation. [PDC 4.7.1.2-7]

\subsubsection{As Low As Is Reasonably Achievable}

The objective of the ALARA program is to assure that radiation doses to occupational workers as well as members of the general public are as far below the regulatory limits as reasonably achievable. This is consistent with the regulatory requirement (10 CFR 20.1101(b) [DIRS 173165]) to use, to the extent practical, procedures and engineering controls based upon sound radiation protection principles to achieve occupational doses and doses to members of the public that are ALARA. The ALARA goals support compliance with the ALARA Management Commitment and Policy (BSC 2001 [DIRS 155183]), and the YMP ALARA Program (BSC 2002 [DIRS 159184]).

In addition, the preliminary design ALARA goal supports compliance with the requirements indicated in NUREG-1804, Yucca Mountain Review Plan, Final Report (NRC [DIRS 163274]) and guidance in Regulatory Guide 8.8, Information Relevant to Ensuring that Occupational Radiation Exposures at Nuclear Power Stations Will be as Low as is Reasonably Achievable [DIRS 103312]. The equipment to be installed within this SDD will assist in meeting the goals and requirements for operation of the facility. During the installation of the equipment under this SDD, locations and methods for installation will be reviewed to assure that these goals and requirements are met. 
3.2.2.1 Requirement: The SNF/HLW transfer system shall be designed and operated to meet ALARA principles. Supports Functions 2.1.2, 2.1.4, and 2.1.5.

Performance Acceptance Criterion: The performance requirements for ALARA considerations will be developed during subsequent design.

Basis: The SNF/HLW transfer system may involve potential worker exposure to ionizing radiation during operation and when maintenance activities are performed. The SNF/HLW transfer system may become contaminated during normal operations and event sequences. The maintenance and replacement activities on this system will consider ALARA in the design and the maintenance and replacement determinations. An ALARA assessment will be applied in all stages of the facility design and construction where there is potential for worker exposure to ionizing radiation. Preliminary emphasis in the ALARA process shall be to incorporate ALARA design considerations throughout the design process. [PRD-015/P015]

\subsubsection{Nuclear Criticality Safety}

A criticality event is unacceptable and the SNF/HLW transfer system shall be designed to preclude a criticality event. Criticality design criteria and codes and standards are given in PDC 4.9.2.1 (BSC 2004 [DIRS 171599]) and criticality safety design criteria are given in PDC 4.9.2.2 (BSC 2004 [DIRS 171599]). As more detailed design becomes available, criticality safety applied to the SNF/HLW transfer system design will be defined as discussed in this section.

3.2.3.1 Requirement: The SNF/HLW transfer system shall be designed and operated to prevent any credible criticality event from occurring. Supports Functions 2.1.2, 2.1.4, and 2.1.5.

Performance Acceptance Criterion: The performance requirements of the SNF/HLW transfer system will be ascertained from the review to prevent the hazards of a criticality safety event.

Basis: The safety classification of the SNF/HLW transfer system is ITS and not ITWI. Nuclear facility safety standards seek to prevent unplanned nuclear criticality events and protect workers and the environment from the potentially harmful exposures. DOE nuclear facility safety programs include concerns for nuclear criticality safety, criticality accident monitoring and alarm system, use of neutron absorbers, and administrative practices for nuclear criticality safety. [PRD-015/P-096]

3.2.3.2 Requirement: The SNF/HLW transfer system shall minimize the potential for criticality in the surface facility; no moderator (water or other hydrogenous materials) shall be present in any area where the presence of a moderator has the potential to adversely effect criticality safety. Supports Function 2.1.5.

Basis: This requirement is necessary to prevent and control criticality. [PDC 4.9.2.2.3]

\subsubsection{Industrial Hazards}

The SNF/HLW transfer system shall include environmental, safety and health requirements related to industrial safety. Included are considerations for protection from heavy moving equipment and hazardous materials.

When detailed operational steps are developed, the industrial hazards will be identified and applicable design criteria and codes and standards will be applied. 
For the SNF/HLW transfer system, the following industrial hazards shall be prevented or mitigated:

- Electrical

- Arcing

- Burns

- Fire

- Shock

- Shorting (faulting)

- Static electricity

- Environmental impacts

- Regulated materials/hazardous substances

- Waste management

- Mechanical

- Fire

- Hydraulic pressure

- Impacts/blunt force

- Implosion from vacuum

- Pneumatic pressure

- Rotating equipment

- Vibration

- Personnel

- Confined space

- Falls

- Lifting

- Pinch points

- Sharp edges/points

- Slips/trips

- Dust/chemicals/physical agents/radon

- Testing/operations/construction/maintenance

- Access/egress

- Cutting

- Elevated work

- Falling objects

- Fire

- Hoisting and rigging

- Mobile/heavy equipment

- Tools. 


\subsubsection{Operating Environment and Natural Phenomena}

Operating environment (e.g., temperature, humidity) will be maintained for the SSCs that are contained within the Waste Processing Facilities.

Portions of the buildings will be designed to withstand all natural phenomena hazard events such as seismic, tornado/high wind, and floods as discussed in PDC 4.2.2 (BSC 2004 [DIRS 171599]) and PDC Section 6 (BSC 2004 [DIRS 171599]). The SNF/HLW transfer system SSCs will be designed to withstand seismic events, as applicable.

3.2.5.1 Requirement: The SNF/HLW transfer system shall be designed to withstand and operate in the temperature environments for the areas in which the components are located. Supports Functions 2.1.1, 2.1.2, 2.1.4, and 2.1.5.

Performance Acceptance Criterion: The SNF/HLW transfer system shall be designed to operate in the applicable environments presented in the PDC, Table 4.8.2-1 (BSC 2004 [DIRS 171599]), Nominal Indoor Design Temperatures and Humidity.

Basis: This requirement is necessary to ensure that the equipment will function properly in the operating environments. [PDC 4.7.1.2-4]

\subsubsection{Human Interface Requirements}

Human interface requirements will be based on experience from existing facilities and design criteria and codes and standards defined in the PDC (BSC 2004 [DIRS 171599]). Details are not yet developed. Appropriate revision of the SDD will incorporate new information as made available.

\subsubsection{Specific Commitments}

3.2.7.1 Requirement: The SNF/HLW transfer system shall be designed and operated in compliance with land access agreements, applicable permits and shall support compliance with applicable environmental, regulatory, monitoring, and mitigation requirements. Supports Functions 2.1.1, 2.1.2, 2.1.3, 2.1.4, and 2.1.5.

Performance Acceptance Criterion: The performance requirements of the SNF/HLW transfer system will be developed during design in conjunction with the development and maintenance of the evaluations performed per Environmental Management Plan (YMP 2000 [DIRS 154039]), applicable permits, Land Access and Environmental Compliance and the Environmental Baseline Review to assure compliance with Environmental Hazard Impacts.

Basis: Environmental hazards (impacts) associated with the SNF/HLW transfer system will be evaluated and controlled in accordance with the Environmental Management Plan (YMP 2000 [DIRS 154039]). AP-EM-002, Land Access and Environmental Compliance, will be utilized to establish compliance with land access agreements and support compliance with applicable environmental regulatory, monitoring, and mitigation requirements. AP-EM-010, Environmental Baseline Review will review the SNF/HLW transfer system design against the Environmental Baseline established by Final Environmental Impact Statement for a Geological Repository for the Disposal of Spent Nuclear Fuel and High-Level Radioactive Waste at Yucca Mountain, Nye County, Nevada (DOE 2002 [DIRS 155970]). The SNF/HLW transfer system is required to comply with federal and state laws, 
regulations, standards, and DOE directives applicable to Environmental Hazards Impacts, Land Access and Environmental Compliance and the Environmental Baseline Review. [PRD-014/P-038, PRD-015/P-075]

3.2.7.2 Requirement: The repository shall be designed with pollution prevention systems to control air emissions and effluents, minimize water use, and reduce or eliminate discharges to the environment. Supports Functions 2.1.1, 2.1.2, 2.1.4, and 2.1.5.

Basis: DOE O 450.1, Environmental Protection Program [DIRS 161567], establishes DOE policy to conduct its operations in an environmentally safe and sound manner, and to perform its activities in compliance with applicable environmental protection requirements. The design shall comply with applicable environmental requirements set forth by federal and state regulations, Executive Orders, and DOE Directives, and requirements derived from environmental permits and corresponding permit conditions. [PDC 4.1.1.9]

3.2.7.3 Requirement: The repository shall be designed with a goal to reduce energy and water consumption while increasing the use of clean energy sources. Supports Function 2.1.5.

Basis: To meet or exceed the goals of the laws, executive orders and federal regulations for energy efficiency, use of renewable energy, and water conservation at DOE facilities. This requirement pledges compliance with 10 CFR 435, Energy Conservation Voluntary Performance Standards for New Buildings; Mandatory for Federal Buildings [DIRS 156267] that provides the minimum standards for energy efficiency goals in the design of new federal buildings. The code provides design requirements for building envelopes, electrical distribution systems, and equipment for electric power, lighting, heating, ventilation, air-conditioning, service water heating, and energy management. This is also in conformance with DOE O 430.2A, Departmental Energy and Utilities Management [DIRS 158913] and 64 FR 30851, Greening the Government Through Efficient Energy Management [DIRS 104026], that provides the goals for the reduction of greenhouse gas emissions attributed to the energy use of federal buildings. [PDC 4.1.1.1]

3.2.7.4 Requirement: The SNF/HLW transfer system shall preclude generation of mixed waste in routine operations. Supports Function 2.1.5.

\section{Performance Acceptance Criteria:}

1. The SNF/HLW transfer system shall separate site-generated hazardous and radioactive waste streams

2. The SNF/HLW transfer system shall be maintained to preclude generation of mixed wastes in routine operations.

Basis: To deter mixing of hazardous and radioactive waste streams. [F\&OR 1.4.1.2.6.2-4]

3.2.7.5 Requirement: The SNF/HLW transfer system shall consider pollution prevention, waste minimization, and recycling. Supports Function 2.1.5.

Performance Acceptance Criterion: A pollution prevention, waste minimization, and recycling capability shall be implemented.

Basis: To assure the public of an environmental conscience SNF/HLW transfer system. [F\&OR 1.4.1.2.6-3] 


\subsection{ENGINEERING DISCIPLINARY REQUIREMENTS AND BASES}

\subsubsection{Civil and Structural}

The civil, structural, and architectural design criteria including codes and standards that apply to the Waste Processing Facilities are given in PDC 4.2.1.1 (BSC 2004 [DIRS 171599]).

\subsubsection{Mechanical and Materials}

The design methods and analytical techniques include loading conditions and material selections for the ITS SSCs. Well established engineering methods, analytical techniques, defining configurations and functions, and selecting materials of construction, are used to evaluate and design ITS SSCs. The designs include normal conditions and those associated with Category 1 and Category 2 event sequences and consequences. The ITS SSCs are designed to meet or exceed design code provisions so that each will safely perform the safety analysis credited design function to ensure compliance with 10 CFR 63 [DIRS 173164]. The design methods and analytical techniques include loading conditions and material selections for the ITS SSCs.

3.3.2.1 Requirement: Recovery features shall be provided for cranes located in radiation areas to retrieve failed cranes to their maintenance areas or provisions for in-place maintenance shall be provided. Supports Function 2.1.4.

Basis: This requirement is necessary to ensure that a failed crane can be recovered from the radiation environment for maintenance activities. [PDC 4.7.1.2-17]

3.3.2.2 Requirement: Grapples and tools shall be designed for ease of decontamination, nondestructive testing, maintenance, handling, and storage. Supports Function 2.1.2.

Basis: [PDC 4.7.1.6-5]

3.3.2.3 Requirement: Equipment, tools, and fixtures in areas with the potential for contamination shall have an appropriate surface finish and geometry to facilitate decontamination and decommissioning and minimize the accumulation and entrapment of contamination. Supports Functions 2.1.1, 2.1.2, 2.1.3, and 2.1.4.

Basis: [PDC 4.7.1.2-8]

3.3.2.4 Requirement: Remote manipulators shall provide capability to recover off-normal scenarios such as release of a stuck grapple/yoke. Supports Function 2.1.4.

Basis: This requirement is necessary to ensure that failed equipment can be recovered from the radiation environment for maintenance activities. [PDC 4.7.1.6-4]

3.3.2.5 Requirement: Fixtures, temporary storage locations, fuel unit container, and similar devices shall be designed with appropriate lead-ins and chamfers to facilitate and guide insertion and removal for remote assembly and disassembly operation. Supports Function 2.1.2.

Basis: [PDC 4.7.1.6-6] 
3.3.2.6 Requirement: Mechanical handling equipment shall be designed to incorporate the use of noncombustible and heat resistant materials to the extent practicable. Supports Functions 2.1.2 and 2.1.5.

Basis: [PDC 4.7.1.2-11]

3.3.2.7 Requirement: Mechanical handling systems and components design shall include | provisions for decontamination and decommissioning. Supports Function 2.1.4.

Basis: [PDC 4.7.1.2-13]

3.3.2.8 Requirement: Mechanical handling systems shall be designed to meet the seismic criteria from PDC Section 6.1.3 (BSC 2004 [DIRS 171599]). Supports Function 2.1.4.

Basis: [PDC 4.7.1.2-2]

3.3.2.9 Requirement: Mechanical handling systems components shall operate satisfactorily in the radiation environment to which they are exposed and shall withstand the cumulative effect of radiation exposure anticipated over their design life. Where the use of radiation-resistant components is not feasible, such components shall be easily replaceable. Supports Function 2.1.1, 2.1.2, 2.1.3, 2.1.4, and 2.1.5.

Basis: [PDC 4.7.1.2-7]

3.3.2.10 Requirement: Mechanical handling systems shall include provisions for the inspection, testing, and maintenance of system equipment. Supports Function 2.1.1, 2.1.2, 2.1.3, 2.1.4 and 2.1.5.

Basis: [PDC 4.7.1.2-10]

3.3.2.11 Requirement: The SNF/HLW transfer system shall incorporate features for safe shutoff of the power supply (i.e., this may include remote and manual disconnects) to the $\mathrm{SNF} / \mathrm{HLW}$ transfer system equipment in an emergency. Supports Function 2.1.4 and 2.1.5.

Basis: [PDC 4.7.1.6-1]

3.3.2.12 Requirement: The SNF/HLW transfer system design shall maintain the capability to continue transfer operations with a single failure in the transfer cell or provide failure recovery capabilities until corrective maintenance can be implemented. Supports Function 2.1.4.

Basis: [PDC 4.7.1.6-2]

3.3.2.13 Requirement: Fixtures, temporary storage locations, fuel unit container, and similar devices shall be designed with appropriate lead-ins and chamfers to facilitate and guide insertion and removal for remote assembly and disassembly operations. Supports Function 2.1 .4 and 2.1.5.

Basis: [PDC 4.7.1.6-6] 


\subsubsection{Chemical and Process}

There are no chemical and process requirements identified for the SNF/HLW transfer system at this time.

\subsubsection{Electrical Power}

The electrical power system is explained and the system requirements are identified in the system design documentation.

Electrical power supplied to the SNF/HLW transfer system is governed by the electrical design criteria and codes and standards given in PDC 4.3.1 (BSC 2004 [DIRS 171599]). As more detailed design becomes available, electrical requirements for the SNF/HLW transfer system will be defined (e.g., electrical requirements for cranes, lighting requirements, emergency power requirements, cable separation requirements) by the equipment suppliers and included in the electrical power system design documentation.

\subsubsection{Instrumentation and Control}

3.3.5.1 Requirement: High resolution video shall be provided to monitor commercial $\mathrm{SNF} / \mathrm{HLW}$ waste package transport, transfer, processing, and SNF aging operations in accordance with the MPEG-2 standard per ISO/IEC 13818-1, [DIRS 166812], ISO/IEC 13818-2, [DIRS 166813], and ISO/IEC 13818-3, [DIRS 166814]. Supports Functions 2.1.1, 2.1.2 and 2.1.3.

Basis: High resolution video is required to provide the digital control and management information system the capability to monitor the various processing areas within the repository. [PDC 4.3.7.14]

3.3.5.2 Requirement: The SNF/HLW transfer system shall provide overload limit sensing, collision avoidance, and alarming capabilities to automatically stop handling operations and warn operators of unsafe conditions. Supports Functions 2.1.1, 2.1.2 and 2.1.3.

Basis: [PDC 4.7.1.2-12]

3.3.5.3 Requirement: The SNF/HLW transfer system shall interface with the site communications network. Supports Functions 2.1.2, 2.1.4, and 2.1.5.

Performance Acceptance Criterion: All repository communications shall be transported on a common synchronous optical network communications backbone in accordance with T1.105-2001, Synchronous Optical Network (SONET) - Basic Description Including Multiplex Structure, Rates, and Format, Including Supplement T1.105a-2002 [DIRS 164162].

Basis: This requirement ensures that the system can adequately communicate with the site network. [PDC 4.3.7.2]

\subsubsection{Computer Hardware and Software}

Design criteria and codes and standards for computer hardware and software will be defined in a later revision. 


\subsubsection{Fire Protection}

The fire protection system is explained and the requirements are identified in the system design documentation.

The SNF/HLW transfer system requires fire protection systems that are governed by the fire protection design criteria and codes and standards given in PDC 4.8.1.1 (BSC 2004 [DIRS 171599]). As more detailed design becomes available, the fire protection system and its interface with the SNF/HLW transfer system will be defined.

Fire hazards are identified for the DTF, CHF, and FHF in the following documentation:

- Dry Transfer Facility: BSC 2005. Dry Transfer Facility No.1-Fire Hazard Analysis [DIRS 172805]

- Canister Handling Facility: BSC 2004. Canister Handling Facility Fire Hazard Analysis [DIRS 168814]

- Fuel Handling Facility: BSC 2004. Fuel Handling Facility Fire Hazard Analysis [DIRS 172147].

\subsection{TESTING AND MAINTENANCE REQUIREMENTS AND BASES}

Details for testing and maintenance requirements are not yet developed. The SDD will incorporate new information as made available. When completed, this section will include reference to PRD-002/T-017 (initial testing) and PRD-014/P-019 (post maintenance testing) (Canori and Leitner 2003 [DIRS 166275]).

\subsubsection{Testability}

No system requirements have been developed for this section at this time.

\subsubsection{Safety-Required Surveillances}

No system requirements have been developed for this section at this time.

\subsubsection{Non-Safety Inspections and Testing}

No system requirements have been developed for this section at this time.

\subsubsection{Maintenance}

No system requirements have been developed for this section at this time. 


\subsection{OTHER REQUIREMENTS AND BASES}

\subsubsection{Security and Special Nuclear Material Protection}

3.5.1.1 Requirement: The SNF/HLW transfer system shall account for and control special nuclear material and high-level waste in its possession.

Comment: The material control and accountability system requirements are identified in the safeguard and security system documentation.

Basis: The repository must account for and control special nuclear material such as access controls, material surveillance, material containment detection and assessment. [F\&OR 2.2.2]

\subsubsection{Special Installation Requirements}

No special installation requirements have been identified.

\subsubsection{Reliability, Availability, and Preferred Failure Modes}

No system requirements have been developed for this section at this time.

\subsubsection{Reliability}

Refer to Section 3.1.1.1 for reliability requirements for the SNF/HLW transfer system equipment.

\subsubsection{Availability}

Availability requirements for each piece of equipment are not yet defined.

\subsubsection{Preferred Failure Modes}

Refer to Section 3.1.1.1 for preferred failure modes of the SNF/HLW transfer system equipment.

\subsubsection{Quality Assurance}

The overall classification of the SNF/HLW transfer system is SC and is subject to the requirements of the quality assurance program described in Quality Assurance Requirements and Description (DOE 2004 [DIRS 171539]). However, no specific quality assurance requirements for the system have been identified at this stage of the design. 


\subsubsection{Miscellaneous Requirements}

\subsubsection{Radiological Waste}

The low-level radioactive waste management system requirements are identified in the system design documentation.

The SNF/HLW transfer system interfaces with the low-level waste management system governed by the waste processing design criteria and codes and standards given in PDC 4.8.4.1. As more detailed design becomes available, the radiological waste system used and its interface with the SNF/HLW transfer system will be defined. 


\section{INTENTIONALLY LEFT BLANK}




\section{SYSTEM DESCRIPTION}

The objective of Section 4 for this revision of the SDD is to describe the current status of the design. The section describes design features currently under development to meet the requirements identified in Section 3.

The content of Section 4 is an assumption based on the rationale that definitive descriptions to demonstrate compliance with requirements are not available at this early stage of the development of this system.

Section 4 will be revised as the design evolves. Comprehensive statements, drawings, and other relevant details that describe how the design meets the requirements identified in Section 3 will be added as they are developed.

Room names and numbers described in Section 4 are taken from:

- Fuel Handling Facility General Arrangement Legend and General Notes (BSC 2004 [DIRS 171814])

- Dry Transfer Facility \#1 /Remediation Facility General Arrangement Legend and General Notes (BSC 2004 [DIRS 170273])

- Canister Handling Facility General Arrangement Legend and General Notes (BSC 2004 [DIRS 171808]).

\subsection{CONFIGURATION INFORMATION}

\subsubsection{Description of System, Subsystems, and Major Components}

\subsubsection{Dry Transfer Facility}

The DTF SNF/HLW transfer system transfers waste from transportation casks into waste packages and prepares loaded and sealed waste packages for delivery to the emplacement and retrieval system. In addition, the system opens DPCs in support of waste transfer operations, transfers SNF into site-specific casks for SNF aging or staging, and prepares casks for undocking from the transfer area. The SNF/HLW transfer system is classified as ITS, see Table 2-1. The system includes SSCs relied on to prevent or mitigate Category 1 and Category 2 event sequences.

The DTF SNF/HLW transfer system consists of the DPC cutting subsystem, dry transfer subsystem, and waste package loadout subsystem (see Figure B-1).

The SNF/HLW transfer system operates within areas of the DTF on Level 0', Level 32', and upper regions of the building for cranes up to Level 75'. The crane areas include provisions for recovery and maintenance. The details of rooms used by the SNF/HLW transfer system are shown on drawings listed in Appendix B. 


\subsection{Dual-Purpose Canister Cutting Subsystem}

Transportation casks containing DPCs are delivered to the DPC cutting subsystem from the cask/MSC/WP preparation system. The cask containing a DPC with a docking ring is on a trolley and is positioned under the docking station in the DPC docking room (1101). The cask is docked, and confinement is established between the cask and the DPC cutting/WP dry remediation cell (1097). The DPC is transferred to the DPC cutting/WP dry remediation cell (1097) using the waste package remediation crane. The DPC is moved to the DPC cutting station where the DPC lid is removed using a cutting machine. The opened DPC is then moved to an unloading area in the cell. The unloading area hatch is opened, and the contents are removed by the dry transfer subsystem. The unloaded DPC and the cut-off lid are then transferred to an overpack that has been docked at the DPC docking port. The DPC is transferred to the low-level waste management system for offsite disposal.

Major components/areas used by the subsystem at the lower level (Level 0'-0") include:

- DPC cutting/WP dry remediation cell

- 100-ton waste package remediation crane

- DPC cutting station

- DPC cutting machine

- Power cutting shear

- DPC grapple or lifting yoke

- Waste package/DPC trolley

- DPC overpacks

- Master/slave manipulators

- Tools for remote maintenance

- DPC/WP transfer hatch.

The 100-ton waste package remediation crane and waste package/DPC trolley are provided by the remediation system.

Dual-Purpose Canister Cutting Station-The DPC cutting station is used to remotely cut the lid off the DPC. The DPC cutting station is classified as ITS, since the opening method must not damage or impact the SNF inside the DPC during the cutting process, see Table 2-1. The DPC cutting station is designed to assure that a seismic event does not cause the station to lose structural integrity.

The DPC cutting station contains a cutting machine, which remotely cuts the lid of a DPC. The DPC cutting station is designed to control the spread of contamination from inside the canister and from the cutting operation during opening of the DPC. The DPC is placed for cutting and the cutting machine is positioned for the desired cut of the DPC wall. The severed lid is lifted for a power shear to reach in and cut off the drainpipe that was used during loading of the DPC. The severed drainpipe is allowed to drop back down into its cavity in the fuel basket.

The DPC cutting station components are constructed of materials suitable for this use and comply with applicable codes and standards. 
Operators control and monitor the DPC cutting station from a local workstation adjacent to the DPC cutting and waste package dry remediation cell. At the workstation, they observe operations on CCTV or through shield windows. Operators may also monitor the machine in the central control center. The two control modes for the DPC cutting station are automatic and manual. In the automatic mode, the operating actions and sequences of operations occur without direct action of the operator. Some operator actions may be necessary to validate specific steps. In the manual mode, manual actions can be performed within a certain operating range, but automatic controls maintain important system set points and parameters.

The DPC cutting station is located in a contaminated and high radiation area. The DPC cutting station maintenance is performed remotely in the DPC cutting/WP dry remediation cell.

Major components used by the DPC cutting station subsystem at the upper levels (Level 32'-0" and above) include:

- DPC docking station

- DPC/waste package transfer hatch.

The DPC cask docking station provides an interface between the DPC docking room with the DPC cutting and waste package dry remediation cell. The DPC cask docking station is similar to the cask and waste package docking stations.

\section{Gas Sampling and Venting}

Prior to breaching its containment, the atmospheric conditions inside the DPC must first be tested to determine what steps to take to prevent uncontrolled releases of flammable gases, crud, or other contaminants. This examination, referred to as gas sampling, will provide a connection to the low-level radioactive waste generating system, and is still under evaluation. Gas sampling and venting will be performed by the SNF/HLW transfer system. Venting the DPC will be implemented, as required, after gas sampling.

\section{Remote Handling of the Dual-Purpose Canister}

The method in which DPCs will be remotely handled is TBD.

\section{Dual-Purpose Canister Cutting}

The DPC transportation cask is docked at the DPC docking port in the DPC docking room (1101). The DPC is lifted out of the cask by the 100-ton waste package remediation crane and moved to the DPC cutting station in the DPC cutting/WP remediation cell (1097).

After the DPC has been opened, the severed lid is lifted for a power shear to reach in and cut off the drainpipe that was used during loading of the DPC. The severed drainpipe is allowed to drop back down into its cavity in the fuel basket.

The DPC lid is removed and the DPC is transferred onto the waste package/DPC trolley by the 100-ton waste package remediation crane and transferred to the WP/DPC unload area of the DPC cutting/WP dry remediation cell (1097) for the transfer of commercial SNF similar to the transfer | 
of commercial SNF from a loaded cask. Commercial SNF transfer is performed by the dry transfer subsystem

After unloading is complete, the WP/DPC trolley with the unloaded DPC is returned to its initial position. The DPC is transferred with the 100-ton waste package remediation crane into an overpack that is docked at the DPC docking port in the DPC docking room (1101) (overpack design is TBD). The overpack, with the unloaded DPC inside is disposed as low-level radioactive waste (TBD).

The range of requirements to cut open the DPC, transfer the commercial SNF to a waste package, and loadout of the unloaded DPC as low-level radioactive waste will be satisfied by the SNF/HLW transfer system. Disposal/removal of the unloaded DPC as low-level radioactive waste will be satisfied by the low-level radioactive waste management system.

\section{Cutting Machine}

The requirement for the DPC cutting/WP dry remediation cell (1097) and its layout was based on the selected method of opening the DPC. Opening the DPC is performed at the DPC cutting station where a cutting machine can be placed in the desired position for cutting the DPC. The design of the DPC cutting machine shall ensure that the DPC lid will prevent damage to the SNF assembly resulting in radiological release should the cutting machine fall into or make contact with the DPC (Section 3.1.1.1.49). The DPC cutting machine shall preclude a radiological release due to damage inflicted upon the DPC contents during the cutting process (Section 3.1.1.1.50). The DPC cutting machine employs "no failure" and "no fall down" safety functions during and after a DBGM-2 seismic event (Section 3.1.1.1.51).

\subsection{Dry Transfer Subsystem}

The dry transfer subsystem performs the following functions:

- Receives loaded transportation casks and loaded site-specific casks containing commercial SNF or DOE SNF/HLW canisters

- Receives empty waste packages and empty or unloaded site-specific casks

- Transfers commercial SNF, DOE SNF canisters, and DOE HLW canisters between loaded transportation casks, site-specific casks, or temporary staging and empty waste packages, empty or unloaded site-specific casks, or temporary staging

- Moves loaded waste packages to the waste package closure cell for closure operations.

Prior to commencing transfer operations, the cask/MSC/WP preparation system prepares the casks, site-specific casks, and waste packages for transfer operations. The dry transfer subsystem uses the same docking port design for transportation casks, site-specific casks, and waste packages. The system provides two docking stations for transportation casks and sitespecific casks and two for waste packages. Confinement to control contamination is established between the transportation casks, site-specific casks, or waste packages and the waste transfer cell through docking rings. 
All necessary handling tools and equipment are engaged based on the specific casks, site-specific casks, or waste packages involved in the transfer operations. The 30-ton waste package docking station gantry crane and 30-ton cask/site-specific cask docking station gantry crane are used to remove the lids from the transportation cask, site-specific cask, or waste package. The SFTM or the 70-ton canister/HLW handling crane is then used to transfer SNF or HLW to a waste package, site-specific cask, or staging area. For a naval cask, preparation is performed in the WP/navy cask preparation room (1053). After preparation the naval cask is moved to the WP loading (navy canister)/docking ring removal cell (1051) and the naval canister is transferred to a waste package positioned in the WP loading/docking ring removal cell (1054). After transfer and lid seat inspection, the cask lid, site-specific cask lid, or the waste package inner lid is replaced and secured, if necessary. A loaded waste package with its inner lid is transferred to the waste package trolley at the entrance to the waste package positioning cell where closure operations are performed. Waste package closure is performed by the waste package closure system. Unloaded transportation casks, loaded site-specific casks, and empty or unloaded sitespecific casks are handled by the cask/MSC/WP preparation system for restoration prior to exiting the DTF.

The dry transfer subsystem operates within lower level elevation (level 0'-0") and multiple upper levels (level 32'-0" elevation and above) inside the DTF building. The dry transfer subsystem transfers SNF and HLW from a loaded cask, site-specific cask, staging rack, or opened DPC to an empty waste package, empty or unloaded site-specific cask, or staging area.

The lower level of the subsystem houses the casks, site-specific casks, and waste packages, which are docked (except for naval canister transfer) and prepared for transfer operations. The upper level of the subsystem includes various components to transfer the SNF/HLW out of the loaded cask, site-specific cask, or DPC and into the empty waste package, empty or unloaded site-specific cask, or staging area.

Major rooms/equipment used by the dry transfer subsystem at the lower level include:

- Cask and MSC docking room (1069) for most casks, including site-specific casks

- Waste package loading (navy canister)/docking ring removal cell (1051)

- Waste package docking cells $(1052,1055)$

- Waste package loading (navy canister)/docking ring removal cells $(1054,1051)$ for transfer of naval canisters

- DPC docking room (1101) for casks containing DPCs

- Tools for remote maintenance.

Major equipment used by the dry transfer subsystem at the upper levels includes:

- SFTM

- Transfer trolley

- Grapples and recovery devices to move the SNF assemblies

- 70-ton canister/HLW handling crane

- Grapples and recovery devices to move the DOE canisters and the MCOs

- 70-ton navy canister handling crane 
- Naval canister grapple

- Naval cask lid grapple

- Naval waste package inner lid grapple and inner lid restraining device actuator

- Two cask docking stations (one also used for site-specific cask loading/unloading) with a shielded-lid handling device

- Two waste package docking stations with a waste package inner lid handling device and inner lid restraining device actuator

- DPC docking station

- Fuel element and canister staging (staging racks) for SNF assemblies and DOE SNF/HLW canisters (10 canisters, 72 BWR assemblies, and 48 PWR assemblies)

- Master/slave manipulators

- Shielded viewing windows

- Tools for remote maintenance.

Canister Grapples-Canister grapples provide the lifting interface between a canister inside the loaded transportation cask or site-specific cask and the canister handling crane. Grapples are provided for various canister types to be processed in the DTF, specifically, DOE SNF canisters, DOE HLW canisters, MCOs, vertical DPCs, and naval canisters. The canister grapples are classified as ITS, see Table 2-1, because grapples are part of the crane assembly that is relied on to minimize the probability of a load drop to less than $1 \times 10^{-5}$ drops/transfer (Section 3.1.1.1.4). The canister grapples design also incorporates features such that the probability of dropping handling equipment from a crane onto an adjacent canister as the canister is being handled is less than or equal to $1 \times 10^{-5}$ for each canister transferred (Section 3.1.1.1.13).

Spent Fuel Transfer Machine-The SFTM is used to move SNF in the waste transfer cell (2048). The machine is classified as ITS and its trolley structure, trolley lateral drive train, bridge structure, grapple, bridge longitudinal drive train, and hoist drive train are ITS components, see Table 2-1. These components are designed to assure the probability of a load drop to less than $1 \times 10^{-5}$ (Section 3.1.1.1.26) drops/transfer, including transfers in single-assembly canisters. The basis for classifying these components as ITS is to control Category 1 and Category 2 event sequences within performance objectives of 10 CFR 63 [DIRS 173164]. The SFTM design prevents lateral movements of handling equipment at a speed that could initiate an event sequence as a result of a collision with a SNF assembly (Section 3.1.1.1.30).

The SFTM is a specialized top-running multiple-girder electric overhead traveling bridge. There is a trolley with a double-hoisting unit capable of rotation about its vertical axis. The bridge and trolley drives each use redundant motors with self-contained gear reduction units. The SFTM is mounted on rails that run along the length of the waste transfer cell and into its crane park area. On loss of power, the SFTM is designed to stop retain the load and enter a locked mode; upon a restoration of power, operator action is required for further movement (Section 3.1.1.1.22). The SFTM design prevents a collapse of the system for loading conditions associated with a DBGM-2 seismic event (Section 3.1.1.1.48) and employs a "maintain waste form" safety function during and after a DBGM-1 seismic event (Section 3.1.1.1.27). The SFTM design includes provisions for assuring that the rate of collisions during an assembly transfer operation is less than or equal to $1 \times 10^{-5}$ collisions/transfer (Section 3.1.1.1.28). The reliability of the 
machine is such that the probability of a drop of handling equipment onto a CSNF assembly with enough energy to breach the assembly is less than $1 \times 10^{-7}$ impacts/transfer for each assembly transferred (Section 3.1.1.1.29).

The rated capacity of the SFTM exceeds the combined weight of the heaviest SNF assembly and associated lifting devices, with design margins specified in ASME NOG-1-2002 [DIRS 158891] and CMAA 70-2000 [DIRS 153997].

Materials of the structural components of the transfer machine are suitable for their use and comply with ASME NOG-1-2002 [DIRS 158891] and CMAA 70-2000 [DIRS 153997].

The SFTM interfaces with crane rails and building walls that support it, and the electrical system, which provides power for the electric bridge, trolley, hoist motors, and brakes. The design of SFTM is such that in the event of a credible fire the temperature will not reach a level that would make it drop its load (Section 3.1.1.1.31). Additionally the drop of a load due to a spurious signal caused by a fire shall have a probability of less than $1 \times 10^{-4}$ over the life of the facility (Section 3.1.1.1.32).

Operators control and monitor the SFTM from local control consoles and they observe operations on CCTV from cameras mounted on the SFTM and through shielded windows. The SFTM is monitored from the central control center on the supervisor console.

The machine can only be controlled from one location at a time. The two control modes are automatic and manual. In the automatic mode, operating actions and sequences of operations occur without direct action of the operator. Some operator actions may be necessary to validate specific steps. In the manual mode, manual actions can be performed within a certain operating range, but automatic controls remain in effect to assure that important system set points and parameters are maintained.

The SFTM may come in contact with radioactive contamination. As a result, the machine is designed and manufactured to limit the retention of contamination and to facilitate decontamination. Access for maintenance and repair is only available when it is in its crane park area.

70-Ton Canister/High-Level Radioactive Waste Handling Crane-The canister/HLW handling crane is used to engage, lift, transfer, and position DOE canisters in the waste transfer cell (2048) and naval canisters from remediated waste packages. The crane is designed to engage and lift different types of canisters arriving in different types of casks. The crane is designed to handle DOE SNF and DOE HLW canisters, naval canisters, and MCO canisters. The crane is not capable of moving above a speed limit for overhead crane transfers such that a collision would cause a breach of the containment of a standardized DOE SNF canister, a DOE HLW canister, or a DOE MCO (Section 3.1.1.1.14). The lift heights for the canisters handled by the canister/HLW handling crane; including the DOE MCO, standardized DOE SNF canister, and DOE HLW canister; are provided in the Nuclear Safety Design Bases, Table C-1 in Appendix C (BSC 2005 [DIRS 171512]) (Section 3.1.1.1.10). 
The canister/HLW handling crane system is designed for loading conditions associated with a DBGM-2 seismic event and does not drop its load. In addition, an analysis shall demonstrate that this crane system has sufficient design margin to ensure that a "no drop" safety function is maintained for loading conditions associated with a BDBGM seismic event (Section 3.1.1.1.9). An auxiliary trolley and hoist are provided for maintenance tasks.

The canister/HLW handling crane is classified as ITS, see Table 2-1. The crane trolley structure, trolley lateral drive train, bridge structure, bridge longitudinal drive train, grapples and hoist drive train are ITS components. The combined failure rate of the canister/HLW handling crane, including hoisting and rigging, is less than $1 \times 10^{-5}$ drops/transfer (Section 3.1.1.1.4). The conditional probability of the canister/HLW handling crane exceeding a lift-height limit, given that a drop has occurred, is less than or equal to $1 \times 10^{-4}$ per lift (Section 3.1.1.1.2). The basis for classifying these components as ITS is to control Category 1 and Category 2 event sequences within the performance objectives of 10 CFR 63 [DIRS 173164].

The canister/HLW handling crane has a top-running multiple-girder electric overhead traveling bridge and a single trolley housing a double-reeving hoisting unit. Redundant motors with self-contained gear reducers drive the bridge and trolley. The hoisting system uses different canister grapples depending on the type of canister to be transferred. On loss of power, the crane is designed to stop and retain the load and enter a locked mode; upon a restoration of power operator action is required for further movement (Section 3.1.1.1.1). Should the instrument and control systems lose their power, they are designed to fail safe and stay in the locked mode until operator action is taken.

The rated crane capacity exceeds the combined weight of the heaviest canister and associated components, with design margins specified in ASME NOG-1-2002 [DIRS 158891] and CMAA 70-2000 [DIRS 153997].

Canister/HLW handling crane components are constructed materials suitable for the purpose for which the materials are used, and comply with applicable codes and standards.

The canister/HLW handling crane interfaces with facility systems, crane rail, supporting the building wall, and the electrical system, which provides power for the gantry, trolley, hoist motors, and brakes. The canister/HLW handling crane design is such that in the event of a credible fire the temperature will not reach a level that would make it drop its load (Section 3.1.1.1.6). A load drop from the canister/HLW handling crane due to a spurious signal caused by a fire shall have a probability of less than $1 \times 10^{-4}$ over the life of the facility (Section 3.1.1.1.7). The canister/HLW handling crane design prevents exerting sufficient force to breach a canister as the result of attempts to overcome mechanical constraints (Section 3.1.1.1.5).

Operators control the canister/HLW handling crane from local control consoles and view operations on CCTV and through shield windows (Section 3.3.5.1). The transmission of the televised images comes from cameras mounted on the crane and in the cell. Operations are also monitored in the central control center.

The crane can only be controlled from one location at a time. The two control modes are automatic and manual. In the automatic mode, operating actions and sequences of operations occur without direct action of the operator. Some operator actions may be necessary to validate 
specific steps. In the manual mode, manual actions can be performed within a certain operating range, but automatic controls remain in effect to assure that important system set points and parameters are maintained. The canister/HLW handling crane is designed such that the drop rate for handling canisters shall be less than or equal to $1 \times 10^{-5}$ drops/transfer, regardless of cause, including human error, failure of equipment such as yokes and grapples, or a combination of the two (Section 3.1.1.1.13).

The canister/HLW handling crane may come in contact with radioactive contamination, but is designed and manufactured to limit the retention of such contamination and to facilitate decontamination.

Access to the crane for maintenance and repair is limited to when the crane is in its crane park area. An auxiliary trolley and hoist are provided to perform necessary maintenance in the waste transfer cell.

Docking Stations-Docking stations provide mechanisms and confinement boundaries that enable the docking of transportation casks, site-specific casks, and waste packages to the waste transfer cell (2048) or the DPC cutting/WP dry remediation cell (1097). The docking stations are classified as ITS, see Table 2-1. Docking stations are designed such that a drop or collision involving components associated with a docking port does not breach the lid of a transportation cask or site-specific cask situated at the docking port (Section 3.1.1.1.52). Docking stations also provide the mechanisms to remove and replace transportation cask, site-specific cask, and waste package lids. Two transportation cask or site-specific cask docking stations connect the waste transfer cell with the Cask and MSC docking room (1069). The two waste package docking stations connect the waste package docking cells (1052 and 1055) to the waste transfer cell. One docking station connects the DPC cask docking cell (1101) to the DPC cutting/WP dry | remediation cell.

Each docking station includes a docking port plug, a mobile slab, and a gantry crane for docking port plug and transportation cask, site-specific cask, and waste package lid removal operations. Docking stations are designed to minimize the waste transfer cell leakage rate during transfer operations and not overturn, derail or lose structural integrity during a seismic event. Docking station cranes are restricted from handling loads that exceed weight or height limits because of possible breach of a waste form if dropped.

Three subcomponents comprise a docking station: a docking port, docking rings, and gantry crane. The docking port consists of a mobile slab and a cell plug. The slab provides the confinement seal between the inside of the waste transfer cell and a docking room, while allowing vertical movement to facilitate the docking of a transportation cask, site-specific cask, or waste package. The cell plug is placed inside the slab to complete the closure of the port when nothing is docked to the waste transfer cell floor. The plug is normally locked to the mobile slab and includes a latching mechanism that attaches to a lift fixture on the lid of the transportation cask, site-specific cask, or waste package being docked. The plug is removed along with the lid.

The docking rings are installed by the cask/MSC/WP preparation system. Docking rings are placed on an incoming transportation cask, site-specific cask, or waste package during the cask 
or waste package preparation process. Docking rings enable the connection of transportation casks, site-specific casks, and waste packages of various diameters to the fixed diameter docking port and minimize the spread of contamination.

The gantry crane places or removes the cell plug; the transportation cask, site-specific cask or waste package lid; and the inner docking ring all together as one element. It consists of a two-drum hoist with a pulley block directly connected to the cell plug. It travels on a short length of track to place or remove the cell plug, lid, and inner docking ring allowing access to the inside of the transportation cask, site-specific cask, or waste package during waste transfer operations.

The three components are of accepted types, suitable for the purposes for which they are used and compliant with applicable codes and standards. The docking port surface in contact with contaminated areas is made primarily of stainless steel to facilitate decontamination. Several seals used to form part of the confinement boundary are made of material resistant to radiation.

Operators control and monitor the docking stations from local control consoles with CCTV and shield windows to view and supervise operations (Section 3.3.5.1).

The docking station can only be controlled from one location at a time. The two control modes are automatic and manual. In the automatic mode, operating actions and sequences of operations occur without direct action of the operator. Some operator actions may be necessary to validate specific steps. In the manual mode, manual actions can be performed within a certain operating range, but automatic controls remain in effect to assure that important system set points and parameters are maintained.

70-Ton Navy Canister Handling Crane-The navy canister handling crane is used to perform naval canister handling operations and waste package docking rings removal in the waste package loading (navy canister) and docking ring removal cell (1051). The crane is designed to prevent movement of a canister, or its handling equipment, at a speed that could cause the canister to breach as the result of a collision. The crane travel rate limit is derived by the analyzed impact the canister is structurally designed to withstand. The lift height limits for the naval SNF canisters handled by this crane are provided in the Nuclear Safety Design Bases, Table C-1 in Appendix C (BSC 2005 [DIRS 171512]) (Section 3.1.1.1.15). The navy canister handling crane system is designed for loading conditions associated with a DBGM-2 seismic event and does not drop its load. In addition, an analysis shall demonstrate that this crane system has sufficient design margin to ensure that a "no drop" safety function is maintained for loading conditions associated with a BDBGM seismic event (Section 3.1.1.1.9).

The navy canister handling crane is classified as ITS and its trolley structure, trolley lateral drive train, bridge structure, grapple, bridge longitudinal drive train, and hoist drive train are ITS components, see Table 2-1. The navy canister handling crane is not capable of moving above a speed limit for overhead crane transfers such that a collision would cause a breach of the containment of a naval SNF canister (Section 3.1.1.1.16). The conditional probability of the navy canister handling crane exceeding a lift-height limit, given that a drop has occurred, is less than or equal to $1 \times 10^{-4}$ per lift (Section 3.1.1.1.2). One of the basis for classifying these 
components as ITS is to control Category 1 and Category 2 event sequences within performance objectives of 10 CFR 63 [DIRS 173164].

The navy canister handling crane is a top-running multiple-girder electric overhead traveling bridge crane, mounted on rails that run the length of the WP loading (navy canister) and docking ring removal cell and into the crane park area. On loss of power, the crane is designed to stop and retain the load and enter a locked mode; upon restoration of power, operator action is required for further movement (Section 3.1.1.1.1). Should the instrument and control systems lose their power, they are designed to fail safe and stay in the locked mode until operator action is taken. The 70-ton rated crane capacity exceeds the combined weight of the heaviest naval canister and associated lifting devices, with the design margins specified in ASME NOG-1-2002 [DIRS 158891] and CMAA 70-2000 [DIRS 153997].

Navy canister handling crane components are constructed of proven performance materials and comply with ASME NOG-1-2002 [DIRS 158891] and CMAA 70-2000 [DIRS 153997]. The crane interfaces with crane rails and building walls that support it and the electrical system, which provides power for the electric bridge, trolley, hoist motors, and brakes. The navy canister handling crane design is such that in the event of a credible fire the temperature of the crane will not reach a level that would make it drop its load (Section 3.1.1.1.6). A load drop from the navy canister handling crane due to a spurious signal caused by a fire shall have a probability of less than $1 \times 10^{-4}$ over the life of the facility (Section 3.1.1.1.7). The navy canister handling crane is designed to prevent spilling the contents of the crane lubrication tank directly or indirectly as a result of the failure of the electrical power supply to the crane.

Operators control and monitor the navy canister handling crane from local control consoles and observe operations on CCTV from cameras mounted on the crane and through shield windows. Operations are monitored from the central control center (Section 3.3.5.1).

The crane can only be controlled from one location at a time. The two control modes are automatic and manual. In the automatic mode, operating actions and sequences of operations occur without direct action of the operator. Some operator actions may be necessary to validate specific steps. In the manual mode, manual actions can be performed within a certain operating range, but automatic controls remain in effect to assure that important system set points and parameters are maintained. The drop rate for the navy canister handling crane is less than or equal to $1 \times 10^{-5}$ drops/transfer, regardless of cause, including human error, failure of equipment such as yokes and grapples, or a combination of the two (Section 3.1.1.1.13). The navy canister handling crane design prevents exerting sufficient force to breach a canister as the result of attempts to overcome mechanical constraints (Section 3.1.1.1.5).

The crane does not directly contact equipment that may be contaminated and is located in an area where no airborne contamination is expected. However, the crane is provided with some provisions to limit the retention of contamination or to facilitate decontamination.

Maintenance, normally hands-on, may be performed in the WP loading and docking ring | removal cell only when there is no radiation source present and the shielded hatches are closed. If a source is present, the crane must be moved to a crane park cell. 
Master/Slave Manipulator-The master/slave manipulator is a device used to perform functions in a hazardous environment. The manipulators and manipulator wall tubes that penetrate the waste transfer cell and DPC cutting and waste package dry remediation cell are required to provide confinement between the cells and the adjoining operating areas. The manipulator consists of a jaw that reproduces the natural movements and forces of the human hand on a handle at a remote workstation. This almost identical movement enables virtual hands-on performance of operations requiring a degree of precision in contaminated areas throughout the DTF. These functions include latching and unlatching grapples, connecting and disconnecting crane attachments, sorting, and packaging waste. The manipulator is also used to perform maintenance and recovery operations and remediation activities. Manipulators are extracted from the manipulator wall tubes in the adjacent or operating corridor. They are pulled into an airtight plastic bag and taken for master/slave manipulator repair.

Transfer Trolley-The transfer trolley is used in various places to move, transfer, and locate waste packages at consistent heights. The trolley provides structural support for waste packages during closure operations and employs a no slap down safety function during and after a DBGM-2 seismic event (Section 3.1.1.1.20). The trolley moves waste packages from the waste package handling and staging cell to the waste package positioning cell and supports the waste package during closure operations. Loaded transfer trolleys are designed to not derail or drop their load during normal operations or as the result of a collision (Section 3.1.1.1.21). In the event of a power loss, the trolley is designed to stop, retain the load, and enter a locked mode; when power is restored, operator action is required for further movement of the trolley (Section 3.1.1.1.19). The trolley rides on a rail system and is designed to secure the trolley and waste package during a seismic event to preclude the possibility of a loaded trolley tipping over and breach of a cask (Section 3.1.1.1.17). The waste package trolley is classified as ITS, see Table 2-1.

Materials of the structural components are suitable for the purpose for which the material is used and comply with applicable codes and standards.

The waste package transfer trolley drive train consists of two motors that are connected to the drive wheels through a gear reducer. One motor is used to drive the trolley, and the other motor provides redundancy. The trolley shall be designed with an inherent speed limit such that a collision at the trolley speed limit would not cause the trolley to drop its load (Section 3.1.1.1.18). In the event of a credible fire in an area where waste forms are present, the temperature of the trolley that handles or transports SNF/HLW shall not reach a level that would make it drop its load (Section 3.1.1.1.25).

The waste package trolley contacts waste packages that are potentially contaminated. Therefore, the trolley is designed and manufactured to limit the retention of radiological contamination and to facilitate decontamination.

Pedestals and Hold-Down Devices-Pedestals are used to ensure a consistent waste package height when mounted on a trolley. The pedestal has locking devices to ensure the pedestal is securely fastened to the trolley. Mounting devices on the pedestals accommodate the various designs of waste packages. The pedestals are classified as ITS and are designed to prevent a 
tipover of their load during normal operations or during and after a DBGM-2 seismic event (Sections 3.1.1.1.17 and 3.1.1.1.24).

Hold-down devices ensure that waste packages are securely fastened to the trolley and pedestal. Trolley and pedestal connections accommodate the hold-down device used for the various designs of waste packages. Hold-down devices are classified as ITS and are designed to prevent a tipover of their load during normal operations or during and after a DBGM-2 seismic event (Sections 3.1.1.1.17 and 3.1.1.1.24).

Materials of the structural components are suitable for the purpose for which the material is used and comply with applicable codes and standards.

The pedestal and hold-down devices contact waste packages that are potentially contaminated. Therefore, they are designed and manufactured to limit the retention of radiological contamination and to facilitate decontamination.

Canister and SNF Staging Racks-The canister and SNF staging racks provide space for staging uncanistered commercial SNF, DOE SNF canisters, and DOE HLW canisters. The staging racks are located in the SNF and canister staging cell (Room 1050). This staging area has the ability to stage a minimum of 72 BWR fuel assemblies, 48 PWR fuel assemblies, and 10 DOE SNF and HLW canisters. The SNF and HLW canister staging racks are ITS, see Table 2-1.

DOE SNF and HLW canister staging racks are actually sealed tubes, not traditional racks. They are designed and placed to maintain criticality safety of SNF canisters during staging (Section 3.1.1.1.44) and structural integrity during a seismic event (Section 3.1.1.1.46). For the purpose of this discussion, the staging racks will be referred to as staging tubes. Minimum spacing for canister staging tubes in the DTF are in accordance with criticality safety calculations presented in Canister Handling Facility Criticality Safety Calculations (BSC 2004 [DIRS 167614]). The individual staging tubes are positioned for forced air cooling with natural convection air cooling backup. For cooling requirements, see the DTF surface industrial HVAC documentation.

The canister staging tube assembly vertically stores one DOE SNF and HLW canister in a protected environment. Criticality safety shall be ensured for commercial SNF assemblies dropped into or onto a commercial SNF assembly staging rack with moderator control in effect (Section 3.1.1.1.45). The staging tube assembly consists of an upper flange, with vertical expansion capability, and a circular tube with a seal plate at the bottom. A tube base assembly supports each staging tube. The tube base assembly is anchored to the vault floor to laterally restrain the bottom of the tube assembly and provide horizontal support during a seismic event. The staging tube assembly provides location and structural restraint for the DOE SNF and HLW canister. In addition, the staging tube assembly provides confinement and cooling for the staged canisters. The bottom of each canister staging tube contains a crush pad to mitigate a canister drop into the tube and prevent Category 2 event sequences.

The BWR and PWR staging tubes store one commercial SNF assembly per tube in a high-integrity controlled environment. BWR and PWR staging tubes are designed and placed to maintain criticality safety (Section 3.1.1.1.43) and structural integrity during a seismic event 
(Section 3.1.1.1.46). Fixed neutron absorbers are included in the staging tubes to ensure adequate safety margin. The criticality safety calculations that govern this design are presented in Surface Facility Criticality Safety Calculations (BSC 2004 [DIRS 168132]). The individual tubes are positioned for forced air cooling with natural convection air cooling backup. For cooling requirements, see the DTF surface industrial HVAC documentation.

Tubes containing the BWR and PWR assemblies are arranged in a staggered pattern, and the assemblies within the tubes are placed near the ceiling of the staging cell (top of staging tube) to aid the flow pattern and increase the cooling efficiency of the system. The staging cell will include a false floor and vertical baffles on the sides to concentrate the flow in the area of the tubes containing the assemblies to maximize heat transfer. The tube arrangement and airflow is designed to prevent exceeding a normal operating maximum temperature criterion of $150^{\circ} \mathrm{F}$ for the staging cell concrete. For all thermal requirements, see DTF 1 Thermal Analysis of the Staging Cell (BSC 2004 [DIRS 171778]).

The staging racks are designed in accordance with ASME Section III, Division 1, Subsection NE, Class MC Components [DIRS 171846] and is fabricated and inspected in accordance with ASI/AISC N690 [DIRS 158835] or ASME Section III [DIRS 171846]. The staging rack base assembly is designed, fabricated, and inspected in accordance with ANSI/AISC N690 [DIRS $158835]$.

\subsection{Waste Package Loadout Subsystem}

The waste package loadout subsystem consists of various components to move, store, survey and decontaminate waste packages, if necessary, and place a loaded and sealed waste package onto the subsurface transport vehicle. The major rooms and cells of the waste package loadout subsystem are the waste package handling and staging cell (1044), the WP/trolley decontamination room (1094), the waste package loadout cell (1088), and the waste package transporter vestibule (1087).

Using the waste package handling crane within the waste package handling and staging cell (1044), the loaded waste package is transferred from the closure cell waste package trolley to the waste package survey station. After an inspection and radiological survey is performed, the waste package handling crane transfers the loaded waste package to the loadout cell waste package trolley for movement to the waste package loadout cell (1088).

Within the waste package loadout cell (1088), the tilting station and waste package loadout handling crane tilts the closed waste packages to a horizontal position on an emplacement pallet. The trunnion collars are then removed with the trunnion collar removal machine. The waste package is transferred into the shielded waste package transporter. The transporter is returned to the waste package emplacement and retrieval system via the waste package transporter vestibule (1087).

The waste package loadout subsystem interfaces with the waste package emplacement and retrieval system and the remediation system. The waste package is removed from the waste package transporter, trunnion collars are installed, up-righted in the waste package loadout cell 
(1088), placed on a waste package trolley, and transferred to the remediation system via the waste package handling and staging cell (1044).

Waste packages are designed to be lifted by the attached trunnion collars only. During loadout operations, once the waste package is tilted and placed on the emplacement pallet and the trunnion collars are removed, the waste package must be lifted and moved by handling the emplacement pallet.

Major equipment used by the waste package loadout subsystem includes:

- 100-ton waste package handling crane, associated yokes, and recovery devices

- Waste package trolley \#1, \#2, and \#3 (to closure)

- Waste package trolley (to decon and waste package remediation)

- Waste package trolley (to loadout)

- Manipulator work station

- Decontamination station and contamination survey station

- 100-ton waste package loadout handling crane, associated yokes, and recovery devices

- Waste package tilting machine including recovery device

- Waste package turntable

- Master/slave manipulators

- Trunnion collar removal machine

- 5-ton trunnion collar crane

- Trunnion collar grapple

- Transporter positioner

- Shield doors

- Shield windows

- Waste package survey and decontamination equipment.

Waste Package Handling Crane-The waste package handling crane is used to remotely engage, lift, transfer, and position loaded waste packages in the waste package handling and staging cell (1044).

The waste package handling crane is classified as ITS and its trolley structure, bridge structure, hoist drive train, and waste package lifting yoke are classified as ITS components, see Table 2-1. The waste package handling crane is designed such that the drop rate for handling waste forms and their associated containers is less than or equal to $1 \times 10^{-5}$ drops/transfer, regardless of cause, including human error, failure of equipment such as yokes and grapples, or a combination of the two (Section 3.1.1.1.13). The conditional probability of the waste package handling crane exceeding a lift-height limit, given that a drop has occurred, is less than or equal to $1 \times 10^{-4}$ per lift (Section 3.1.1.1.2). The lift height limits for the sealed and unsealed, loaded waste packages handled by the waste package handling crane are provided in the Nuclear Safety Design Bases, Table C-1 in Appendix C (BSC 2005 [DIRS 171512]) (Section 3.1.1.1.3).

On loss of power, the crane is designed to stop and retain the load and enter a locked mode; upon restoration of power, operator action is required for further movement (Section 3.1.1.1.1). Should the instrumentation and control systems lose their power, they are designed to fail safe 
and stay in the locked mode until operator action is taken and give accurate indication upon power restoration.

The waste package handling crane is not capable of moving above a speed limit for overhead crane transfers such that a collision would cause a breach of the containment of a loaded, sealed waste package (Section 3.1.1.1.11). The waste package handling crane system is designed for loading conditions associated with a DBGM-2 seismic event and does not drop its load. In addition, an analysis shall demonstrate that this crane system has sufficient design margin to ensure that a "no drop" safety function is maintained for loading conditions associated with a BDBGM seismic event (Section 3.1.1.1.9).

The waste package handling crane design is such that in the event of a credible fire the temperature will not reach a level that would make it drop its load (Section 3.1.1.1.6). A drop of a load from the DTF waste package handling crane due to a spurious signal caused by a fire has a probability of less than $1 \times 10^{-4}$ over the life of the facility (Section 3.1.1.1.7). The waste package handling crane design prevents exerting sufficient force to breach a waste package as the result of attempts to overcome mechanical constraints (Section 3.1.1.1.8).

Engineered features are included in the crane design to limit the lift of a waste package to prevent exceeding the design basis drop height. The lift heights and load paths are restricted to assure the crane does not drop a waste package that could breach a waste package or waste form. Additionally, for other loads carried by the crane, the lift heights and load paths are restricted to assure the crane does not drop a load that could breach a waste package or waste form. The crane or its loads are prevented from inadvertently coming into contact with SSCs. The engineered features include mechanical stops, encoders, and limit switches/interlocks in the crane control circuitry. Limit switches/interlocks stop the crane or hoisting before mechanical stops are reached.

The waste package handling crane is a top-running multiple-girder electric overhead traveling bridge. The main trolley uses a double-reeving hoisting unit. The bridge and trolley drives each use redundant motors with self-contained gear reduction units.

The 100-ton rated capacity of the crane exceeds the combined weight of the heaviest waste package and associated lifting devices with design margins specified in ASME NOG-1-2002 [DIRS 158891] and CMAA 70-2000 [DIRS 153997].

Materials of the structural components of the crane are suitable for their use and comply with applicable codes and standards. The crane interfaces with crane rails and building walls that support it and the electrical system, which provides power for the electric bridge, trolley, hoist motors, and brakes. The electrical system also provides an uninterruptible power supply for the instrumentation and control system.

Operators control and monitor the waste package handling crane from local control consoles and observe operations on CCTV and through shield windows. Operators may also monitor crane operations in the central control center. A pendant control is used in the crane park area during maintenance. 
The crane can only be controlled from one location at a time. The two control modes are automatic and manual. In the automatic mode, operating actions and sequences of operations occur without direct action of the operator. Some operator actions may be necessary to validate specific steps. In the manual mode, manual actions can be performed within a certain operating range, but automatic controls remain in effect to assure that important system set points and parameters are maintained.

The waste package handling crane is located in a low-contamination, high-radiation area in the DTF. The crane is provided with some provisions to limit the retention of contamination and to facilitate decontamination. The crane is designed to operate in the high-radiation area. Crane maintenance is performed in the crane park cell.

The waste package handling crane is equipped with an auxiliary trolley and hoist to transport tools and components needed to perform maintenance and repair operations in the waste package handling and staging cell. Non-routine access is permitted in the cell only when waste packages are removed from the area.

Waste Package Lifting Yoke-The waste package lifting yoke serves as the lifting interface between the loaded waste package and the waste package handling crane in the DTF waste package handling and staging cell (1044). The waste package lifting yoke is used to lift loaded unsealed waste packages from the waste package trolley, with its inner lid, to the waste package trolley at the entrance to the waste package positioning cell where closure operations are performed. After waste package closure is completed, the waste package lifting yoke is used to lift the sealed loaded waste package from the positioning cell transfer trolley to the waste package loadout transfer trolley located in the waste package loadout cell (1088).

The waste package loadout cell (1088) contains an identical waste package lifting yoke for operations in the waste package loadout area. In this area the yoke interfaces with the waste package loadout handling crane and is used to lift the sealed loaded waste package from the loadout transfer trolley to the waste package loadout tilting machine which tilts the waste package to a horizontal position onto the waste package pallet.

The lifting yoke is classified as ITS, see Table 2-1, because it is part of the crane assembly that is relied on to minimize the probability of a load drop to less than $1 \times 10^{-5}$ drops/transfer (Section 3.1.1.1.13). The waste package lifting yoke is designed to remain intact and not drop a load during a DBGM-2 seismic event (Section 3.1.1.1.23). The waste package lifting yoke design incorporates features so that it will not cause a breach of the waste package if dropped onto the inner lid or from the maximum possible height.

The waste package lifting yoke has a beam that supports two lifting arms, which are on opposite sides of the beam, and connects to the waste package crane and waste package loadout crane pulley block. The yoke structure is fitted with a motorized center of gravity adjustment device A motor-driven assembly adjusts the arms to engage the waste package trunnions. The waste package lifting yoke arms are interchangeable. A motorized jack actuates a locking mechanism on each arm to secure the yoke to the waste package. The yoke design is such that it will have a failure rate of less than or equal to $1 \times 10^{-5}$ drops/transfer for lifting a waste package containing SNF/HLW (Section 3.1.1.1.13). 
Interfaces between the waste package lifting yoke and other facility systems include the basic structural connection between the yoke beam and the waste package handling crane pulley block. Additional interfaces include the structural interface between the lifting yoke lifting arms and the waste package trunnions and the electrical interface between the lifting arm motor drive and the electrical power system.

Materials of the structural components are suitable for the purpose for which the material is used and comply with applicable codes and standards.

An operator controls the waste package lifting yoke from the same local console from where the waste package handling crane is operated.

The waste package lifting yoke contacts waste packages that may be contaminated. Therefore, the yoke is designed and manufactured to limit the retention of radiological contamination and to facilitate decontamination.

The rated capacity of the lifting yoke exceeds the weight of the heaviest anticipated loads, with design margins specified in ANSI N14.6-1993 [DIRS 102016]. The waste package lifting yoke is maintained and periodically tested in accordance with ANSI N14.6-1993 [DIRS 102016] and ASME B30.20-2003 [DIRS 171688].

Waste Package Loadout Handling Crane-The waste package loadout handling crane is used to remotely engage, lift, transfer, and position loaded waste packages within the waste package loadout cell (1088) where levels of radiation prevent personnel from entering. The waste package loadout handling crane is classified as ITS and its trolley structure, bridge structure, hoist drive train, and waste package lifting yoke are classified as ITS components, see Table 2-1. On loss of power, the crane is designed to stop and retain the load and enter a locked mode; upon restoration of power operator action is required for further movement (Section 3.1.1.1.1). Should the instrument and control systems lose their power, they are designed to fail safe and stay in the locked mode until operator action is taken and give accurate indication upon power restoration.

The waste package loadout handling crane is not capable of moving above a speed limit for overhead crane transfers such that a collision would cause a breach of the containment of a loaded, sealed waste package (Section 3.1.1.1.11).

The waste package loadout handling system is be designed for loading conditions associated with a DBGM-2 seismic event and does not drop its load. In addition, an analysis shall demonstrate that this crane system has sufficient design margin to ensure that a "no drop" safety function is maintained for loading conditions associated with a BDBGM seismic event (Section 3.1.1.1.9). Engineered features are included in the crane design to limit the lift of a waste package to prevent exceeding the drop height. The lift heights and load paths are restricted to assure the crane does not drop a waste package that could breach a waste package or waste form. Additionally, for other crane loads, lift heights and load paths are restricted to assure the crane does not drop a load that could breach a waste package or waste form. The waste package loadout handing crane or its load is prevented from inadvertently coming into contact with SSCs. The crane is restricted from lowering a waste package onto the waste 
package tilting machine until the tilting machine and waste package turntable, with an emplacement pallet, is in proper position to receive the waste package.

The waste package loadout handling crane design is such that in the event of a credible fire the temperature will not reach a level that would make it drop its load (Sections 3.1.1.1.6). A load drop from the DTF waste package loadout handling crane due to a spurious signal caused by a fire will have a probability of less than $1 \times 10^{-4}$ over the life of the facility (Section 3.1.1.1.7). Engineered features include mechanical stops as well as limit switches/interlocks in the crane control circuitry. The limit switches/interlocks stop the crane or hoisting before mechanical stops are reached.

The waste package loadout handling crane is designed such that the drop rate for handling waste forms and their associated containers is less than or equal to $1 \times 10^{-5} \mathrm{drops} /$ transfer, regardless of cause, including human error, failure of equipment such as yokes and grapples, or a combination of the two (Section 3.1.1.1.13). The conditional probability of the waste package loadout handling crane exceeding a lift-height limit, given that a drop has occurred, is less than or equal to $1 \times 10^{-4}$ per lift (Section 3.1.1.1.2). The lift height limits for the sealed waste packages containing commercial SNF, standardized DOE SNF canisters, DOE HLW canisters, naval SNF canisters, and DOE MCOs handled by the waste package loadout handling crane are provided in the Nuclear Safety Design Bases, Table C-1 in Appendix C (BSC 2005 [DIRS 171512]) (Section 3.1.1.1.12).

The waste package loadout handling crane is a top-running multiple-girder electric overhead traveling bridge crane. The main trolley uses a double-reeving, hoisting unit. The bridge and trolley drives each use redundant motors with self-contained gear reduction units.

The 100-ton rated capacity of the crane exceeds the combined weight of the heaviest waste package and associated lifting devices with design margins specified in ASME NOG-1-2002 [DIRS 158891] and CMAA 70-2000 [DIRS 153997].

Waste package loadout handling crane components are constructed of proven performance materials suitable for their use and comply with applicable codes and standards The crane interfaces with crane rails and building walls that support it and the electrical system, which provides power for the electric bridge, trolley, hoist motors, and brakes. The electrical power system also provides an uninterruptible power supply for the instrumentation and control system. Should the instrumentation lose its power, it is designed to give proper indication upon power restoration.

Operators control and monitor the crane from local control consoles and observe operations on CCTV from cameras mounted on the crane, in the cell, and through shield windows. Operators may also monitor the crane operations in the central control center. A pendant control is used in the crane park area during maintenance activities.

The crane can only be controlled from one location at a time. The two control modes are automatic and manual. In the automatic mode, operating actions and sequences of operations occur without direct action of the operator. Some operator actions may be necessary to validate specific steps. In the manual mode, manual actions can be performed within a certain operating 
range, but automatic controls remain in effect to assure that important system set points and parameters are maintained.

The waste package loadout handling crane is located in a low-contamination, high-radiation area in the DTF. However, the crane is provided with some provisions to limit the retention of contamination and to facilitate decontamination. Crane maintenance is performed in the crane park cell (2081). A shielded door permits personnel access to the crane park cell.

The waste package loadout handling crane is equipped with an auxiliary trolley and hoist to perform maintenance and repair operations in the waste package loadout cell Maintenance access is permitted in the cell only when unshielded waste packages are removed or isolated from the area.

Waste Package Tilting Machine-The waste package tilting machine along with the waste package loadout handling crane is used to tilt sealed waste packages to a horizontal position. The waste package tilting machine is classified as ITS, see Table 2-1. The design of the waste package tilting machine employs a no slap down safety function during and after a DBGM-2 seismic event (Section 3.1.1.1.34). The waste package tilting machine is designed to assure that a seismic event does not cause the tilting machine to release the waste package, overturn, derail, or lose structural integrity. The tilting machine is designed not to move or release the lock on the waste package trunnions while the waste package is being tilted and lowered onto the emplacement pallet (Section 3.1.1.1.33). . The design of the waste package tilting machine ensures that an impact or collision between the waste package tilting machine and a waste package shall not breach the containment of the waste package or cause it to fall off the emplacement pallet (Section 3.1.1.1.36). The engineered features include mechanical locking devices, position detectors, and interlocks in the tilting machine control circuitry.

The waste package tilting machine is located in the waste package loadout cell (1088). The waste package arrives suspended vertically from the waste package loadout handling crane. The waste package tilting machine provides support pockets that interface with the lower waste package trunnions and keeps them in position but allows rotation. The waste package loadout handling crane then lowers the upper end to position the waste package onto the emplacement pallet.

The waste package tilting machine has three active drive mechanisms. The first is the drive train, which is used to move the trolley in either direction on its track. The drive train consists of two drive motors powering two drive wheels through a transmission/reducer gearbox. The second drive mechanism is used to lock the waste package trunnions into the waste package tilting machine pockets. There are two independent locking systems, one on each trunnion support. Each locking system is powered by an electric motor that extends the lock bar over the trunnion. The third drive mechanism is the locking device that locks the trolley in the proper position on the track. This trolley position locking system is designed to prevent movement during and after a seismic event such that a backwards slap down could occur (Section 3.1.1.1.35). The machine interfaces with the electrical system, which provides power for the drives. On loss of power, the tilting machine is designed to maintain its position and the lock on the trunnions; on restoration of power, operator action is required for further operation. The electrical power system also provides an uninterruptible power supply for the 
instrumentation and control system. The instrumentation and control systems used to control the waste package loadout tilting machine has a failure rate less than or equal to $1 \times 10^{-4} /$ transfer. Should the instrumentation lose its power, it is designed to fail safe, stay in the locked mode until operator action is taken, and give accurate indication upon power restoration.

Waste package tilting machine components are constructed of materials suitable for their use and comply with applicable codes and standards.

Operators control and monitor the waste package tilting machine from a local control console and observe operations on CCTV using cameras mounted in the cells. The tilting machine is monitored remotely at consoles in the central control center. The waste package tilting machine can only be operated from one location at a time.

The waste package tilting machine is located in a low-contamination, high-radiation area in the DTF. However, the tilting machine is provided with some provisions to limit the retention of contamination and to facilitate decontamination.

Waste Package Turntable-The waste package turntable is located in the waste package loadout cell (1088). The waste package turntable receives the emplacement pallet from the waste package transporter and the waste package is then lowered to the horizontal position onto the pallet using the waste package loadout handling crane and the waste package tilting machine. The turntable also aligns the waste package for removal of the trunnion collars by the trunnion collar removal machine. It then positions the emplacement pallet with the waste package for receipt by the waste package transporter. The transporter extends the bedplate under the emplacement pallet and the turntable lowers the pallet onto the bedplate. The waste package turntable accommodates the various waste packages. The waste package turntable is classified as ITS, see Table 2-1.

The waste package turntable is designed to assure that the turntable maintains its structural integrity during a seismic event and that the turntable does not release the emplacement pallet. The waste package turntable employs a no-tipover safety function during and after a DBGM-2 seismic event (Section 3.1.1.1.39). The waste package turntable is designed to not prematurely actuate while the waste package is being lowered onto the emplacement pallet or during the trunnion collar removal, the waste package tilting machine, and the transporter bedplate are not in their retracted positions (Section 3.1.1.1.37). The engineered features include mechanical locking devices, position detectors, and interlocks in the turntable control circuitry.

Waste package turntable structural components are suitable for use and comply with applicable codes and standards. The turntable interfaces with the electrical system, which provides power for the drives. The electrical power system also provides an uninterruptible power supply for the instrumentation and control system. Should the instrumentation lose its power, it is designed to fail safe, stay in the locked mode until operator action is taken, and give accurate indication upon power restoration. The design of the waste package tilting machine ensures that an impact or collision between the waste package turntable and a waste package does not breach the containment of the waste package or cause it to fall off the emplacement pallet (Section 3.1.1.1.38). 
Operators control and monitor the waste package turntable from local control consoles and observe operations on CCTV and through shield windows. The turntable is monitored remotely at consoles in the central control center. The waste package turntable can only be operated from one location at a time.

The waste package turntable has drive mechanisms. A drive mechanism rotates the turntable. Other drive mechanisms raise and lower the waste package and emplacement pallet.

The waste package turntable is located in a low-contamination, high-radiation area in the DTF. However, the turntable is provided with some provisions to limit the retention of contamination and to facilitate decontamination.

Waste Package Survey and Decontamination Equipment-Waste package survey and decontamination equipment and functions relating to the SNF/HLW transfer system is currently TBD. Waste package survey samples will be collected using remote manipulators, passed out of the survey room via a special port, and measured using dedicated portable instruments. Surveying for removable contamination will consist of conventional smear techniques for quantitative analyses and large area wipes for qualitative analyses.

When thorough decontamination is required, the sealed waste package will be moved to a dedicated shielded WP/trolley decontamination room (1094) where decontamination will be performed using remotely controlled manipulators. Following the decontamination operation, a survey of the waste package surface will be performed to demonstrate that the level of external removable contamination on the waste package is within guidelines.

The survey and decontamination equipment designs are not complete. They are currently in the selection process to determine the most efficient configurations for performing this process.

Trunnion Collar Removal Machine-The trunnion collar removal machine located in room 1091 is used to remove the top and bottom trunnion collars of waste packages. The trunnion collar removal machine is classified as ITS, see Table 2-1. The lateral drive train, translation drive mechanism, trunnion gripping drive mechanism, and the rotation drive mechanism are ITS components. The design of the trunnion collar removal machine is such that it will not cause a waste package to drop from the emplacement pallet during use (Section 3.1.1.1.40). The trunnion collar removal machine employs "no slapdown" and "no breach" safety functions during and after a DBGM-2 seismic event (Section 3.1.1.1.41). The trunnion collar removal machine accommodates the various waste package trunnion collar sizes. The trunnion collar removal machine moves between the collar removal machine area and the waste package loadout cell. It moves along tracks on the floor to the waste package loadout cell when the waste package is positioned on the turntable ready for trunnion collar removal. . The design of the trunnion collar removal machine is such that an impact or collision between the trunnion collar removal machine and a waste package will not breach the containment of the waste package or cause it to fall off the emplacement pallet (Section 3.1.1.1.42). The waste package trunnion collar removal machine attaches to the trunnion collar and rotates the collar for removal. After removal the trunnion collar, is placed in a trunnion collar stand to be prepared for later reuse. The trunnion collars are decontaminated, if required, and returned to the Warehouse and Nonnuclear Receipt Facility for reuse. 
The trunnion collar removal machine has four active drive mechanisms. The first is the drive train, which is used to move the machine in either direction on its track. The drive train consists of two drive motors powering two drive wheels through a transmission/reducer gearbox. The second drive mechanism is the translation motor, used to position the trunnion gripping arm onto the trunnions. The third drive mechanism is the trunnion gripping arm actuator, used to lock the arm to the trunnion collar. The fourth drive mechanism is the rotation motor, used to rotate the trunnion gripping arm and engaged trunnion collar to disengage the collar from the waste package.

Trunnion collar removal machine components are constructed of materials suitable for the use, and comply with applicable codes and standards. The machine interfaces with the electrical system, which provides power for the drives. On loss of power, the trunnion collar removal machine is designed to stop and retain the grip on the trunnion collar; on restoration of power, operator action is required for further movement. The electrical power system also provides an uninterruptible power supply for the instrumentation and control system. Should the instrumentation lose its power, it is designed to give proper indication upon power restoration.

Operators control and monitor the trunnion collar removal machine from a local workstation adjacent to the waste package loadout cell. At the workstation, they observe operations on CCTV and through shield windows. Operators may also monitor the machine in the central control center.

The trunnion collar removal machine is located in a low-contamination, high-radiation area in the DTF. However, the machine is provided with some provisions to limit the retention of contamination and to facilitate decontamination.

Trunnion Collar Crane-The trunnion collar crane is used to handle the trunnion collars after removal from the waste package. The crane is classified as not ITS. The rated capacity of the crane exceeds the weight of the heaviest anticipated load, with design margins specified in CMAA 70-2000 [DIRS 153997]. Crane components are constructed of proven performance materials and comply with applicable codes and standards.

The trunnion collar crane operates in a high radiation area where no contamination is expected. Therefore, there are no design or manufacturing requirements to limit the retention of contamination or to facilitate decontamination.

Transporter Positioner-The transporter positioner is used to locate the transporter after it has been decoupled from its prime mover The positioner is classified as not ITS.

The transporter positioner interfaces with the electrical power system, which provides power for the electric drives.

Materials of the structural components of the transporter positioner are of an accepted type, suitable for the purposes for which they are used. The materials are compliant with applicable codes and standards. The transporter positioner operates in a low-contamination, high-radiation area in the DTF. 


\subsubsection{Canister Handling Facility}

The CHF SNF/HLW transfer system contains SSCs necessary to transfer DOE SNF and DOE HLW canisters and commercial SNF in DPCs. The DOE SNF and HLW canisters can be transferred from transportation casks to waste packages for emplacement or to the canister transfer area staging pit for temporary staging. Commercial SNF in vertical DPC can be unloaded from transportation casks and loaded into site-specific casks for staging. The $\mathrm{SNF} / \mathrm{HLW}$ transfer system is classified as ITS, see Table 2-1. The system contains SSCs that are relied upon to prevent or mitigate Category 1 and Category 2 event sequences.

The CHF SNF/HLW transfer system consists of the dry transfer subsystem and the waste package loadout subsystem (see Figure B-1).

The SNF/HLW transfer system consists of areas of the CHF on Level 0', Level 32', and upper regions of the building for cranes up to Level 40'. The crane areas include provisions for recovery and maintenance. The details of the rooms used by the SNF/HLW transfer system is shown on drawings listed in Appendix B.

\subsection{Dry Transfer Subsystem}

The dry transfer subsystem performs the following functions:

- Receives loaded transportation casks containing DOE SNF/HLW canisters or commercial SNF in DPCs.

- Receives empty waste packages and empty or unloaded site-specific casks

- Transfers DOE SNF and HLW canisters between loaded transportation casks, empty waste packages and temporary staging tubes. The dry transfer system also transfers commercial SNF in vertical DPCs to empty or unloaded site-specific casks for staging on the aging pad.

- Moves loaded waste packages to the waste package closure cell for closure operations.

- Moves loaded site-specific casks to the cask/MSC/WP preparation system for transfer to the aging facility.

Prior to commencing transfer operations, the cask/MSC/WP preparation system prepares the casks, site-specific casks, and waste packages for transfer operations. All necessary handling tools and equipment are staged based on the specific casks, site-specific casks, or waste packages involved in the transfer operations. Personnel are evacuated from the canister transfer cell (1033) before transfer operations start, but they reenter as necessary after radiation sources are shielded or removed. The 100-ton waste package and canister handling crane is used to remove the lids from the transportation cask, site-specific cask, or waste package. The waste package and canister handling crane is then used to transfer SNF and HLW canisters to a waste package, or to the canister transfer area staging pit for temporary staging. Commercial SNF in vertical DPCs are transferred to site-specific casks, for staging. Specific grapples are used to lift the various types of canisters. After canister transfer and lid seat inspection, the cask lid, 
site-specific cask lid, or the waste package inner lid is replaced and secured, if necessary. A loaded waste package is transferred with its inner lid from the site-specific cask/waste package loading pit to the waste package trolley at the entrance to the waste package positioning cell where closure operations are performed. Waste package closure is performed by the waste package closure system. Unloaded transportation casks and loaded site-specific casks are handled by the cask/MSC/WP preparation system for restoration prior to exiting the CHF.

The dry transfer subsystem operates within 0 '-0" and $-23^{\prime}-0$ " lower level elevations and multiple upper levels (level 32'-0" elevation and above) inside the CHF. The dry transfer subsystem transfers SNF/HLW from a loaded transportation cask to an empty waste package or a vertical DPC from a loaded transportation cask to an empty or unloaded site-specific cask. The pits, which are at level -23'-0", are equipped with pedestals for height control and crush pads to mitigate any potential drop during transfer operations. The crush pads limit the energy transferred to less than or equal to the impact specified for a drop onto an unyielding surface for the cask or canister.

The lower levels of the dry transfer subsystem houses the transportation casks, site-specific casks, and waste packages in their appropriate pits where they are prepared for transfer operations. The upper level of the subsystem includes various components to transfer the SNF/HLW or DPC out of the loaded transportation cask into the empty waste package, staging pit, or empty or unloaded site-specific cask.

Major components and areas used by the dry transfer subsystem at the lower levels include:

- Cask preparation pit (P002)

- $\mathrm{MSC} / \mathrm{WP}$ loading pit (P004)

- $\mathrm{MSC} / \mathrm{WP}$ loading pit (P003)

- Canister staging pit (P001)

- Grapples and recovery devices to move the various loads in the transfer cell (DOE SNF, DOE HLW, MCO, DPC, transportation cask lid, site-specific cask lid, waste package inner lids, and pit plugs)

- Waste package inner lid restraining device actuator

- Waste package trolley

- Storage stands for grapples

- Master/slave manipulator work stations

- Tools for remote handling

- 200-ton cask handling crane

- 100-ton waste package and canister handling crane

- Waste package trolley.

The CHF mechanical handling components operate in an environment classified as having a low potential for contamination and any equipment, tools, or fixtures in areas with the potential for contamination shall have specific design and manufacturing requirements imposed that facilitate decontamination and minimize the accumulation of contamination (Section 3.3.2.3). 
The cask handling crane and the waste package and canister handling cranes belong to the cask/MSC/WP preparation system.

Canister Grapples-Canister grapples provide the lifting interface between a canister inside the loaded transportation cask or site-specific cask and the waste package and canister handling crane. Grapples are provided for various canister types to be processed in the CHF, specifically, DOE SNF canisters, DOE HLW canisters, MCOs, vertical DPCs, and naval canisters. The canister grapples are classified as ITS, see Table 2-1, because they are part of the crane assembly that is relied on to minimize the probability of a load drop to less than $1 \times 10^{-5} \mathrm{drops} /$ transfer. The canister grapples are designed to remain intact and not drop a load during a DBGM-2 seismic event. The canister grapples design also incorporates features such that the probability of dropping handling equipment from a crane onto an adjacent canister as the canister is being handled is less than or equal to $1 \times 10^{-5}$ for each canister transferred.

Waste Package Trolley-The waste package trolley provides structural support for waste packages during closure operations and employs a no slap down safety function during and after a DBGM-2 seismic event. The trolley moves waste packages from the main transfer room to the waste package positioning cell and supports the waste package during closure operations. Loaded transfer trolleys shall not derail or drop their load during normal operations or as the result of a collision. In the event of a power loss, the trolley is designed to stop, retain the load, and enter a locked mode; when power is restored, operator action is required for further movement of the trolley. The trolley rides on a rail system and is designed to secure the trolley and waste package during a seismic event to preclude the possibility of a loaded trolley tipping over. The waste package trolley is classified as ITS, see Table 2-1.

Materials of the structural components are suitable for the purpose for which the material is used and comply with applicable codes and standards.

The waste package trolley drive train consists of a motor connected to the drive wheels through a gear reducer. The trolley shall be designed with an inherent speed limit such that a collision at the trolley speed limit would not cause the trolley to drop its load. In the event of a credible fire in an area where waste forms are present, the temperature of the trolley that handles or transports $\mathrm{SNF} / \mathrm{HLW}$ shall not reach a level that would make it drop its load.

The waste package trolley contacts waste packages that are potentially contaminated. Therefore, the trolley is designed and manufactured to limit the retention of radiological contamination and to facilitate decontamination.

Pedestals and Hold-Down Devices-Pedestals are used to ensure a consistent waste package height when mounted on a trolley. The pedestal has locking devices to ensure the pedestal is securely fastened to the trolley. Mounting devices on the pedestals accommodate the various designs of waste packages. The pedestals are classified as ITS and are designed to prevent a tipover of their load during normal operations or during and after a DBGM-2 seismic event.

Hold-down devices ensure that waste packages are securely fastened to the trolley and pedestal. Trolley and pedestal connections accommodate the hold-down device used for the various 
designs of waste packages. Hold-down devices are classified as ITS and are designed to prevent tipover of their load during normal operations or during and after a DBGM-2 seismic event.

Materials of the structural components are suitable for the purpose for which the material is used and comply with applicable codes and standards.

The pedestal and hold-down devices contact waste packages that are potentially contaminated. Therefore, they are designed and manufactured to limit the retention of radiological contamination and to facilitate decontamination.

Canister Staging Racks-The canister staging racks provide space for staging DOE SNF canisters and DOE HLW canisters. The staging racks are in the canister staging pit (P001) located in the canister transfer cell (1033). This staging area has the ability to stage a minimum of ten DOE SNF and HLW canisters. The SNF and HLW canister staging racks are ITS, see Table 2-1.

DOE SNF and HLW canister staging racks are actually sealed tubes, not traditional racks, designed and placed to maintain criticality safety of SNF and HLW canisters during staging (Section 3.1.1.1.44) and structural integrity during a seismic event (Section 3.1.1.1.47). For the purpose of this discussion, the staging racks will be referred to as staging tubes. Minimum spacing for canister staging tubes in the $\mathrm{CHF}$ are in accordance with criticality safety calculations presented in Canister Handling Facility Criticality Safety Calculations (BSC 2004 [DIRS 167614]). The individual staging tubes are positioned for forced air cooling with natural convection air cooling backup. Cooling requirements and spacing are presented in Thermal Analysis of the Canister Pits and Staging Area (BSC 2004 [DIRS 170938]).

The canister staging tube assembly vertically stores one DOE SNF and HLW canister in a protected environment. The staging tube assembly consists of an upper flange with vertical expansion capability and a circular tube with a seal plate at the bottom. A tube base assembly supports each staging tube. The tube base assembly is anchored to the vault floor to laterally restrain the bottom of the tube assembly and provide horizontal support during a seismic event. The staging tube assembly provides location and structural restraint for the DOE SNF and HLW canister. In addition, the staging tube assembly provides confinement and cooling for the staged canisters. The bottom of each canister staging tube contains a crush pad to mitigate a canister drop into the tube and prevent Category 2 event sequences.

The staging racks are designed in accordance with ASME Section III, Division 1, Subsection NE, Class MC Components [DIRS 171846] and is fabricated and inspected in accordance with ASI/AISC N690 [DIRS 158835] or ASME Section III [DIRS 171846]. The staging rack base assembly is designed, fabricated, and inspected in accordance with ANSI/AISC N690 [DIRS $158835]$.

\subsection{Waste Package Loadout Subsystem}

This waste package loadout subsystem receives sealed waste packages after closure operations and prepares them for transfer to the emplacement and retrieval system. 
After closure, loaded and sealed waste packages are transferred from the waste package closure system to the canister transfer cell where loadout operations are performed. These operations include postclosure waste package inspections and surveys, followed by tilting operations to place the waste packages in a horizontal position on an emplacement pallet. The waste package trunnion collars are removed, and the sealed waste package and emplacement pallet are loaded onto the waste package transporter for subsequent emplacement.

The waste package loadout subsystem consists of various components to move and place a loaded waste package onto the subsurface transport vehicle. The rooms, areas and cells of the waste package loadout subsystem are the canister transfer cell (1033), waste package positioning cells $(1011,1042)$, and the exit vestibule (1031).

The waste package trolley moves the sealed waste package from the waste package positioning cells $(1011,1042)$ to the canister transfer cell $(1033)$. Within the canister transfer cell, the waste package is surveyed at the waste package survey area, then the waste package tilting machine and the waste package and canister-handling crane tilt the sealed waste packages to a horizontal position on an emplacement pallet and the trunnion collar removal machine removes the waste package trunnion collars. Finally, the waste package with its emplacement pallet is loaded into the shielded waste package transporter by the waste package and canister handling crane.

Waste packages are lifted by the attached trunnion collars only prior to loadout. After the sealed waste package is on the emplacement pallet, the trunnion collars are removed and the waste package must be lifted and moved by handling the emplacement pallet.

Major equipment used by the system inside the transfer cell include:

- Waste package and canister handling crane

- Waste package lifting yoke

- Waste package trolley

- Waste package tilting machine

- Trunnion collar removal machine

- Waste package survey station

- Waste package survey manipulator

- Waste package turntable

- Waste package/pallet lifting yoke

- Master/slave manipulator work stations

- Tools for maintenance.

Waste Package Survey Station-The waste package survey station performs the waste package contamination survey. The waste package survey station is not classified as ITS. The waste package survey station consists of a robotic arm mounted on a vertical mast supported by the wall, which travels up and down to provide coverage to the entire length of the waste package as the waste package is rotated. This operation can be observed from a shield window that provides direct view of the waste package from the loadout operating gallery (1017). A wall mounted smear sample transfer station safely transfers smear samples from the transfer cell area (1033) to the loadout operating gallery (1017) where smear counting equipment is located. The smear sample transfer station also transfers clean smear pads into the transfer cell (1033) area for use. 
The waste package survey station is located between the waste package positioning cell (1011) and the waste package tilting machine. A waste package is transferred to the waste package survey area from the waste package trolley after waste package closure operations have been completed. This is performed by using the 100-ton crane. The waste package is hoisted in front of the shield window and rotated at a slow rpm while the robotic hand loaded with a smear pad is held against the waste package surface. Smear samples are taken and transferred to the loadout operating gallery (1017) for counting and recording. The robotic arm is capable of reaching the entire surface of the waste package including the top and bottom areas.

The waste package survey station is operated from a local control station adjacent to the canister transfer cell in the loadout operating gallery (1017). Operations are viewed through shield windows and by using closed-circuit television cameras that are installed in the cell. The waste package survey station operations are monitored remotely at consoles in the central control centerWaste Package Lifting Yoke-The waste package lifting yoke serves as the lifting interface between the loaded waste package and the waste package and canister handling crane in the CHF canister transfer cell (1033). The lifting yoke is classified as ITS, see Table 2-1, because it is part of the crane assembly that is relied on to minimize the probability of a load drop to less than $1 \times 10^{-5}$ drops/transfer. The waste package lifting yoke is designed to remain intact and not drop a load during a DBGM-2 seismic event (Section 3.1.1.1.23). The waste package lifting yoke design incorporates features so that it will not cause a breach of the waste package if dropped onto the inner lid or from the maximum possible height.

The waste package lifting yoke has a beam that supports two lifting arms, which are on opposite sides of the beam, and connects to the waste package and canister handling crane pulley block. A motor-driven assembly adjusts the arms to engage the waste package trunnions. The waste package lifting yoke arms are interchangeable. A motorized jack actuates a locking mechanism on each arm to secure the yoke to the waste package. The yoke design is such that it will have a failure rate of less than or equal to $1 \times 10^{-5}$ drops/transfer for lifting a waste package containing $\mathrm{SNF} / \mathrm{HLW}$.

Interfaces between the waste package lifting yoke and other facility systems include the basic structural connection between the yoke beam and the waste package and canister handling crane pulley block. Additional interfaces include the structural interface between the lifting yoke lifting arms and the waste package trunnions and the electrical interface between the lifting arm motor drive and the electrical power system.

Materials of structural components are suitable for the purpose for which the material is used and comply with applicable codes and standards.

The lifting arm motor drive is operated from the local control consoles that operate the main transfer room crane.

The waste package lifting yoke contacts waste packages that may be contaminated. Therefore, the yoke is designed and manufactured to limit the retention of radiological contamination and to facilitate decontamination. 
The rated capacity of the waste package lifting yoke is specified to envelope the weight of the heaviest waste package plus design margins specified in ANSI N14.6-1993 [DIRS 102016]. The waste package lifting yoke is maintained and tested in accordance with ANSI N14.6-1993 [DIRS 102016] and ASME B30.20-2003 [DIRS 171688].

Waste Package Tilting Machine-The waste package tilting machine along with the waste package and canister handling crane is used to tilt sealed waste packages to a horizontal position. The waste package tilting machine is classified as ITS, see Table 2-1. The design of the waste package tilting machine employs a no slap down safety function during and after a DBGM-2 seismic event. The waste package tilting machine is designed to assure that a seismic event does not cause the tilting machine to release the waste package, overturn, derail, or lose structural integrity (Section 3.1.1.1.34). The tilting machine is designed not to move or release the lock on the waste package trunnions while the emplacement pallet is being raised to receive the weight of the waste package, and while the waste package is being tilted (Section 3.1.1.1.33). The design of the waste package tilting machine is such that an impact or collision between the waste package tilting machine and a waste package shall not breach the containment of the waste package or cause it to fall off the emplacement pallet (Section 3.1.1.1.36). The engineered features include mechanical locking devices and position detectors and interlocks in the tilting machine control circuitry.

The waste package tilting machine is located in the canister transfer cell (1033). Waste packages arrive suspended vertically from the 100-ton waste package and canister handling crane. The waste package tilting machine provides support pockets that interface with the lower waste package trunnions and keeps them in position but allows rotation. The crane then lowers the upper end to position the waste package onto the emplacement pallet.

The waste package tilting machine has three active drive mechanisms. The first is the drive train, which is used to move the trolley in either direction on its track. The drive train consists of two drive motors powering two drive wheels through a transmission/reducer gearbox. The second drive mechanism is used to lock the waste package trunnions into the waste package tilting machine pockets. There are two independent locking systems, one on each trunnion support. Each locking system is powered by an electric motor that extends the lock bar over the trunnion. The third drive mechanism is the locking device that locks the trolley in the proper position on the track. This trolley position locking system is designed to prevent movement during and after a seismic event such that a backwards slap down could occur (Section 3.1.1.1.35). The machine interfaces with the electrical system, which provides power for the drives. On loss of power, the tilting machine is designed to maintain its position and the lock on the trunnions; on restoration of power, operator action is required for further operation. The electrical power system also provides an uninterruptible power supply for the instrumentation and control system. The instrumentation and control systems used to control the waste package loadout tilting machine has a failure rate less than or equal to $1 \times 10^{-4} /$ transfer. Should the instrumentation lose its power, it is designed to fail safe; stay in the locked mode until operator action is taken, and give accurate indication upon power restoration.

Waste package tilting machine components are constructed of materials suitable for their use and comply with applicable codes and standards. 
Interfaces for the waste package tilting machine include the ties to the electrical power system, which provides power for the electric drive. The waste package tilting machine is operated from local control consoles adjacent to the canister transfer cell. Operations are viewed through shield windows and by using CCTV cameras that are installed in the cell. The tilting machine is monitored remotely at consoles in the central control center. The waste package tilting machine can only be operated from one location at a time.

The waste package tilting machine is located in a low-contamination, high-radiation area in the CHF. However, the tilting machine is provided with some provisions to limit the retention of contamination and to facilitate decontamination.

Waste Package Turntable- The waste package turntable is located in the canister transfer cell (1033). The waste package turntable receives the emplacement pallet from the waste package transporter and the waste package is then lowered to the horizontal position onto the pallet using the waste package and canister handling crane and the waste package tilting machine. The turntable also aligns the waste package for removal of the trunnion collars by the trunnion collar removal machine. It then positions the emplacement pallet with the waste package for transfer to the waste package transporter. The waste package turntable is classified as ITS, see Table 2-1.

The waste package turntable is designed to ensure that the turntable maintains its structural integrity during seismic events. The waste package turntable employs a no-tipover safety function during and after a DBGM-2 seismic event (Section 3.1.1.1.39). The turntable is designed not to rotate while the waste package is tilted and when the emplacement pallet is raised to accept the weight of the waste package. The waste package turntable is designed to not prematurely actuate (while holding the waste package on an emplacement pallet) before the disengagement of the trunnion collar removal machine (Section 3.1.1.1.37). It is also designed not to move when the trunnion collar removal machine is removing the waste package trunnion collars and when the waste package tilting machine is being disengaged and retracting from the waste package. The engineered features include mechanical locking devices and position detectors and interlocks in the turntable control circuitry. Should the instrumentation lose its power, it is designed to fail safe, stay in the locked mode until operator action is taken, and give accurate indication when power is restored. . The design of the waste package turntable is such that an impact or collision between the waste package turntable and a waste package will not breach the containment of the waste package or cause it to fall off the emplacement pallet (Section 3.1.1.1.38).

The waste package turntable allows a 180-degree turn of the waste package during collar removal operations. The turntable support structure is designed to support the heaviest, fully loaded waste package emplacement pallet in the CHF, its own weight, plus safety margins.

The turntable turning system drive motors provide 360-degree rotational movement and vertical movement of the turntable. Motors are provided to engage and disengage the turntable locking mechanism that holds the turntable in position when aligned with the waste package tilting machine or waste package collar removal machine.

Waste Package Trunnion Collar Removal Machine-The waste package trunnion collar removal machine located in room 1033 is used to remove the top and bottom trunnion collars 
from loaded waste packages. The waste package collar removal machine is classified as ITS, see Table 2-1. The lateral drive train, translation drive mechanism, trunnion gripping drive mechanism, and the rotation drive mechanism are ITS components.

The design of the waste package trunnion collar removal machine is such that it will not cause the waste package to drop from the emplacement pallet during use. The design also prevents the premature actuation of the waste package turntable while holding the waste package on an emplacement pallet and before disengagement of the trunnion collars (Section 3.1.1.1.40). The machine is also designed for loading conditions associated with a DBGM-2 seismic event to prevent slapdown of the waste package. In addition, an analysis shall demonstrate that the trunnion collar removal machine system has sufficient seismic design margin to ensure that "no slapdown" and "no breach" safety functions are maintained for loading conditions associated with a BDBGM seismic event (Section 3.1.1.1.41).

The waste package trunnion collar removal machine accommodates the various waste package trunnion collar sizes. The waste package trunnion collar removal machine is located in the canister transfer cell adjacent to the waste package turntable. It moves into position when the waste package is positioned on the turntable ready for trunnion collar removal. . The design of the waste package trunnion collar removal machine is such that an impact or collision between the trunnion collar removal machine and a waste package shall not breach the containment of the waste package or cause it to fall off the emplacement pallet (Section 3.1.1.1.42). The waste package trunnion collar removal machine attaches to the trunnion collar and rotates the collar to remove it. After removal of the trunnion collar, the collar is placed in a trunnion collar stand to be prepared for later reuse. The trunnion collars are decontaminated, if required, and returned to the Warehouse and Non-nuclear Receipt Facility for reuse.

The waste package trunnion collar removal machine components are constructed of materials suitable for their use, and comply with applicable codes and standards. The machine interfaces with the electrical system, which provides power for the drives. On loss of power, the waste package trunnion collar removal machine is designed to stop and retain the grip on the trunnion collar; on restoration of power, operator action is required for further movement. The electrical power system also provides an uninterruptible power supply for the instrumentation and control system. Should the instrumentation lose its power, it is designed to fail safe and give proper indication upon power restoration.

Operators control and monitor the waste package trunnion collar removal machine from the waste package loadout operating gallery (1017) adjacent to the canister transfer cell (1033). At the workstation, they observe operations on CCTV and through shield windows. Operators may also monitor the machine in the central control center.

The waste package trunnion collar removal machine is located in a low-contamination, highradiation area in the $\mathrm{CHF}$. However, the machine is provided with design features to limit the retention of contamination and to facilitate decontamination.

Waste Package/Pallet Lifting Yoke-The waste package/pallet lifting yoke serves as the lifting interface between the loaded waste package on its emplacement pallet, which it engages, and the waste package and canister handling crane. The lifting yoke is classified as ITS, see Table 2-1, 
because it is part of the crane assembly that is relied on to minimize the probability of a load drop to less than $1 \times 10^{-5}$ drops/transfer. The waste package/pallet lifting yoke is designed for loading conditions associated with a DBGM-2 seismic event. In addition, an analysis shall demonstrate that the crane lifting yokes have sufficient seismic design margin to ensure that a "no drop" safety function is maintained for loading conditions associated with a BDBGM seismic event (Section 3.1.1.1.23). In addition, the yoke is designed so that it will not breach a waste package if dropped from the maximum possible height.

The waste package/pallet lifting yoke attaches directly to the load block of the waste package and canister handling crane. A yoke beam supports the yoke arms and connects to the crane load block. The yoke structure is fitted with a motorized center of gravity adjustment device. The yoke arms are controlled by a motor-driven assembly that engages the emplacement pallet in four locations. The yoke design is such that it has a failure rate of less than or equal to $1 \times 10^{-5}$ drops/transfer for lifting a waste package containing SNF/HLW.

Interfaces between the waste package/pallet lifting yoke and other facility systems include the basic structural connection between the yoke beam and the waste package and canister handling crane pulley block. Additional interfaces include the structural interface between the lifting yoke lifting arms and the emplacement pallet and the electrical interface between the lifting arm motor drive and the electrical power system.

Materials of structural components are suitable for the purpose for which the material is used and comply with applicable codes and standards.

The lifting arm motor drive is operated from the local control consoles that operate the waste package and canister handling crane.

The waste package/pallet lifting yoke is not considered potentially contaminated, but the yoke is designed and manufactured to limit the retention of radiological contamination and to facilitate decontamination. The waste package/pallet lifting yoke is stored and used inside the canister transfer cell.

The rated capacity of the waste package/pallet lifting yoke is specified to envelope the weight of heaviest waste package and associated emplacement pallet plus design margins specified in ANSI N14.6-1993 [DIRS 102016]. The waste package/pallet lifting yoke is maintained and tested in accordance with ANSI N14.6-1993 [DIRS 102016] and ASME B30.20-2003 [DIRS 171688].

\subsubsection{Fuel Handling Facility}

The FHF SNF/HLW transfer system contains SSCs necessary to transfer canistered and uncanistered SNF and HLW from transportation casks or site-specific casks to waste packages for emplacement underground. The SNF/HLW transfer system also transfers SNF from transportation casks to site-specific casks for SNF aging or staging. Commercial DPCs can also be unloaded from transportation casks and loaded in site-specific casks for staging. The $\mathrm{SNF} / \mathrm{HLW}$ transfer system is classified as ITS, see Table 2-1. The system contains SSCs that are | relied upon to prevent or mitigate Category 1 and Category 2 event sequences. 
The FHF SNF/HLW transfer system consists of the dry transfer subsystem and the waste package loadout subsystem (see Figure B-1).

The SNF/HLW transfer system consists of areas of the FHF on Level 0', Level 32', and upper elevations of the building. The crane areas include provisions for recovery and maintenance. The details of the rooms used by the SNF/HLW transfer system are shown on drawings listed in Appendix B.

\subsection{Dry Transfer Subsystem}

The dry transfer subsystem performs the following functions:

- Receives loaded transportation casks and loaded site-specific casks containing SNF assemblies.

- Receives empty waste packages and empty or unloaded site-specific casks

- Transfers commercial SNF, DOE SNF canisters and DOE HLW canisters between loaded transportation casks, site-specific casks, and empty waste packages or empty or unloaded site-specific casks.

Prior to commencing transfer operations, the cask/MSC/WP preparation system prepares the transportation casks, site-specific casks, and waste packages for transfer operations. All necessary handling tools and equipment are staged based on the specific casks, site-specific casks, or waste packages involved in the transfer operations. Personnel are evacuated from the main transfer room (1003) before transfer operations start, but they reenter as necessary after sources are shielded or removed. The main transfer room crane is used to remove the lids from the transportation cask, site-specific cask, or waste package. A spent fuel transfer machine is

used to transfer individual fuel assemblies. Special grapples are used to handle DPCs being transferred to site-specific casks for aging or staging and to lift the various other types of canisters. After fuel and canister transfers, the cask lid, site-specific cask lid, or the waste package inner lid is replaced and secured if necessary. A loaded waste package is transferred with its inner lid from the main transfer room (1003) to the waste package positioning cell (1013) where closure operations are performed. Unloaded transportation casks, loaded site-specific casks, and unloaded site-specific casks are handled in the main transfer room (1003) and preparation room (1002) for restoration prior to exiting the FHF. Cask restoration is a subsystem of the cask/MSC/WP preparation system.

The dry transfer subsystem operates within $0^{\prime}-0$ " lower level elevation and multiple upper levels (level 32'-0" elevation and above) inside the FHF building to transfer the SNF/HLW from a loaded cask or site-specific cask to an empty waste package or an empty or unloaded sitespecific cask or to transfer a vertical DPC from a loaded cask to an empty or unloaded sitespecific cask. The areas of the dry transfer subsystem are the main transfer room (1003), fuel transfer bays $(1004,1005,1006)$, and the fuel transfer room (2001).

The lower level of the subsystem houses the transportation casks, site-specific casks, and waste packages and their appropriate room or transfer bays where they are prepared for transfer 
operations. The upper levels of the subsystem include various components to transfer the SNF assemblies out of the loaded transportation cask or site-specific cask into the empty waste package or empty or unloaded site-specific cask.

Major components/areas used by the subsystem at the lower levels (elevation $0^{\prime}-0$ ", and 32'-0") | include:

- Spent fuel transfer machine

- Docking stations

- Fuel transfer maintenance crane

- Main transfer room crane (1003)

- Canister grapple

- Main transfer room (1003)

- Fuel transfer bay \#1 (1004)

- Fuel transfer bay \#2 (1005)

- Fuel transfer bay \#3 (1006)

- Fuel transfer room (2001).

Spent Fuel Transfer Machine-The spent fuel transfer machine is used to move SNF in the fuel transfer room (2001). The machine is classified as ITS, see Table 2-1. Its trolley structure, trolley lateral drive train, bridge structure, grapple, bridge longitudinal drive train, and hoist drive train are ITS components. The crane components are designed to assure the probability of a load drop to less than $1 \times 10^{-5}$ drops/transfer (Section 3.1.1.1.26). The basis for classifying these components as ITS is to control Category 1 and Category 2 event sequences within performance objectives of 10 CFR 63 [DIRS 173164].

The spent fuel transfer machine is designed for loading conditions associated with a DBGM-1 seismic event to demonstrate sufficient seismic margin and to ensure that a "maintain waste form" safety function is maintained (Section 3.1.1.1.27). The spent fuel transfer machine design prevents lateral movements of handling equipment at a speed that could initiate an event sequence as a result of a collision with a SNF assembly (Section 3.1.1.1.30).

The spent fuel transfer machine is a specialized top-running multiple-girder electric overhead traveling bridge. There is a trolley with a double-hoisting unit capable of rotation about its vertical axis. The spent fuel transfer machine has a power manipulator arm mounted on the trolley for obtaining radiological swipes, attaching lifting devices to the spent fuel transfer machine, and performing other remote activities in the high-radiation environment. The bridge and trolley drives each use redundant motors with self-contained gear reduction units. The spent fuel transfer machine is mounted on rails that run the length of the fuel transfer room. On loss of power, the spent fuel transfer machine is designed to stop, retain the load, and enter a locked mode; upon a restoration of power, operator action is required for further movement (Section 3.1.1.1.22). The spent fuel transfer machine employs a no-fall safety function during and after a DBGM-1 and DBGM-2 seismic event and employs a retain waste from safety function during and after a DBGM-1 seismic event (Section 3.1.1.1.48). The design of the spent fuel transfer machine ensures that the frequency of collision is less than or equal to $1 \times 10^{-5}$ collisions/transfer (Section 3.1.1.1.28). The design of the machine is such that the probability of dropping handling 
equipment onto a commercial SNF assembly with enough energy to breach the assembly shall be less than $1 \times 10^{-7} \mathrm{impacts} /$ transfer for each assembly transferred (Section 3.1.1.1.29).

The rated capacity of the spent fuel transfer machine exceeds the combined weight of the heaviest SNF assembly and associated lifting devices, with design margins specified in ASME NOG-1-2002 [DIRS 158891] and CMAA 70-2000 [DIRS 153997].

Materials of the structural components of the machine are suitable for their use and comply with ASME NOG-1-2002 [DIRS 158891] and CMAA 70-2000 [DIRS 153997].

The spent fuel transfer machine interfaces with crane rails and building walls that support it, and the electrical system, which provides power for the electric bridge, trolley, hoist motors, and brakes. The spent fuel transfer machine is designed to remain structurally intact and have no load drop due to the maximum credible fire (Section 3.1.1.1.31). A load drop from the spent fuel transfer machine due to a spurious signal caused by a fire will have a probability of less than $1 \times$ $10^{-4}$ over the life of the facility (Section 3.1.1.1.32).

Operators control and monitor the spent fuel transfer machine from local control consoles in the fuel transfer operating gallery (2002) and they observe operations on CCTV from cameras mounted on the machine. The spent fuel transfer machine is monitored from the central control center on the supervisor console.

The machine can only be controlled from one location at a time. The two control modes are automatic and manual. In the automatic mode, operating actions and sequences of operations occur without direct action of the operator. Some operator actions may be necessary to validate specific steps. In the manual mode, manual actions can be performed within a certain operating range, but automatic controls remain in effect to assure that important system set points and parameters are maintained.

The spent fuel transfer machine may come in contact with radioactive contamination. As a result, the machine is designed and manufactured to limit the retention of contamination and to facilitate decontamination.

Docking Stations-Docking stations provide mechanisms and confinement boundaries that enable the docking of transportation casks, site-specific casks, and waste packages to the fuel transfer room (2001). Docking stations include the ability to raise, lower, and properly match the elevation of the docking ring that has been placed on top of the transportation cask, site-specific cask, and waste package to ensure proper fit-up and a tight seal between the mating surfaces. Docking stations also provide the confinement necessary to remove and replace the lids of transportation casks, site-specific casks, and waste packages. There are three docking stations in the FHF. The docking station components; lid grapple, mechanical seal, and port form part of the confinement system for the fuel transfer room (2001) during fuel transfer operations. These components are also used to minimize the potential for the spread of radioactive materials from the fuel transfer room (2001) to the fuel transfer bays below (1004, 1005, and 1006) when the transportation cask, site-specific cask, and waste package is docked or when the port plugs are installed. 
Each docking station includes a docking port plug and a removable slab. Docking stations are designed to minimize the fuel transfer room leakage rate during transfer operations and not overturn, derail or lose structural integrity during a seismic event. Docking station cranes are restricted from handling loads that exceed weight or height limits because of possible breach of a waste form if dropped.

The two subcomponents that comprise a docking station are a docking port and docking ring. The docking port consists of a removable slab and a port plug. The slab provides the confinement seal between the inside of the fuel transfer room and a fuel transfer bay, while allowing vertical movement to facilitate the docking of a transportation cask, site-specific cask, or waste package. The port plug is placed inside the slab to complete the closure of the docking station when nothing is docked to the fuel transfer room. The plug is normally locked to the removable slab and includes a latching mechanism that attaches to a lift fixture on the lid of the transportation cask, site-specific cask, or waste package being docked. The port plug is removed along with the lid by the fuel transfer maintenance crane.

The second docking station component is the docking ring assembly. Docking rings are placed on an incoming transportation cask, site-specific cask, or waste package during the cask or waste package preparation process. Docking rings enable the connection of transportation casks, site-specific casks, and waste packages of various diameters to the fixed diameter docking port and minimize the spread of contamination.

The fuel transfer maintenance crane places or removes the port plug, the transportation cask, site-specific cask or waste package lid, and the inner docking ring all together as one element.

All materials are suitable for the intended purpose and comply with applicable codes and standards. The surface of the docking port that contacts contaminated areas is made primarily of stainless steel to facilitate decontamination. Several seals are used to form part of the containment boundary. Materials resistant to radiation damage are used for the docking port. Operators control and monitor the docking stations from local control consoles in the fuel transfer operating gallery (2002) with CCTV to view and supervise operations. Local operations are viewed through shield windows.

The docking station can only be controlled from one location at a time. The two control modes are automatic and manual. In the automatic mode, operating actions and sequences of operations occur without direct action of the operator. Some operator actions may be necessary to validate specific steps. In the manual mode, manual actions can be performed within a certain operating range, but automatic controls remain in effect to assure that important system set points and parameters are maintained.

Main Transfer Room Crane-The main transfer room crane is used to perform canister transfer operations at the canister transfer station and transfer loaded waste packages from one transfer trolley to another to permit the movement of the loaded waste package into the waste package closure room. In addition, the main transfer room crane is used by the cask/MSC/WP preparation system in the main transfer room. See the cask/MSC/WP preparation system design documentation for further discussion. 
Fuel Transfer Maintenance Crane-The fuel transfer maintenance crane is used to engage, lift, transfer, and position docking station port plugs and perform maintenance tasks in the fuel transfer room (2001). The crane has a top-running multiple-girder electric overhead traveling bridge and a single trolley. The crane is classified as ITS, see Table 2-1. Its trolley structure, trolley lateral drive train, bridge structure, bridge longitudinal drive train, grapples and hoist drive train are ITS components.

The fuel transfer maintenance crane is mounted on rails that run the length of the fuel transfer room. On loss of power, the fuel transfer maintenance crane is designed to stop, retain the load, and enter a locked mode; upon a restoration of power, operator action is required for further movement (Section 3.1.1.4.6). The fuel transfer maintenance crane and grapples is designed for loading conditions associated with a DBGM-1 seismic event to demonstrate sufficient seismic design margin to ensure that a "maintain waste form" safety function is maintained (Section 3.1.1.4.7). The fuel transfer maintenance crane and anchorages is designed to prevent collapse of the system for loading conditions associated with a DBGM-2 seismic event. In addition, an analysis shall demonstrate that the fuel transfer maintenance crane and anchorages have sufficient seismic design margin to ensure that a "no fall down" safety function is maintained for loading conditions associated with a BDBGM seismic event (Section 3.1.1.4.8). The reliability of the maintenance crane is such that it has a failure rate of less than (to be defined in future revision of the NSDB for SNF/HLW transfer) drops per transfer (Section 3.1.1.4.9).

Materials of the structural components of the machine are suitable for their use and comply with ASME NOG-1-2002 [DIRS 158891] and CMAA 70-2000 [DIRS 153997].

The crane interfaces with facility systems, crane rail, supporting the building wall, and the electrical system, which provides power for the gantry, trolley, hoist motors, and brakes. The fuel transfer maintenance crane is designed to remain structurally intact and have no load drop due to the maximum credible fire (Section 3.1.1.4.10). The fuel transfer maintenance crane is also designed to prevent uncontrolled movement resulting from the maximum credible fire.

Operators control the crane from local control consoles and view operations on CCTV (Section 3.1.1.4.4). The transmission of the televised images comes from cameras mounted on the crane and in the cell. A viewing window from the adjacent fuel transfer operating gallery (2002) is provided for each of the three docking stations (2001) for operator direct viewing of the fuel transfer operations (Section 3.3.5.1). Operations are also monitored in the central control center.

The crane can only be controlled from one location at a time. The two control modes are automatic and manual. In the automatic mode, operating actions and sequences of operations occur without direct action of the operator. Some operator actions may be necessary to validate specific steps. In the manual mode, manual actions can be performed within a certain operating range, but automatic controls remain in effect to assure that important system set points and parameters are maintained.

The fuel transfer maintenance crane may come in contact with radioactive contamination, but is designed and manufactured to limit the retention of such contamination and to facilitate decontamination. 
Access to the crane for maintenance and repair is limited to when the crane is in its crane park area.

Canister Grapple-A canister grapple provides the lifting interface between a canister inside the loaded transportation cask and the main transfer room crane. The grapples are classified as ITS, see Table 2-1, because they are part of the crane assembly that is relied on to minimize the probability of a load drop to less than $1 \times 10^{-5}$ drops/transfer. The canister grapples are designed to remain intact and not drop a load during a DBGM-2 seismic event. The canister grapples design also incorporates features such that the probability of dropping handling equipment from a crane onto an adjacent canister as the canister is being handled is less than or equal to $1 \times 10^{-5}$ for each canister transferred.

\subsection{Waste Package Loadout Subsystem}

The waste package loadout subsystem receives loaded and sealed waste packages after closure operations and prepares them for transfer to the emplacement pallet and waste package transporter.

After closure, sealed waste packages are transferred from the waste package positioning cell to the main transfer room, where loadout operations are performed. These operations include waste package inspections and surveys, followed by tilting operations to place the waste packages in a horizontal position on an emplacement pallet. The waste package trunnion collars are removed and the sealed waste package and emplacement pallets are loaded onto the waste package transporter for subsequent emplacement.

The waste package loadout subsystem consists of various components to move and place a loaded waste package onto the subsurface transport vehicle. The rooms or areas of the waste package loadout subsystem are the main transfer room (1003) and the entrance vestibule (1001).

The waste package closure trolley moves the loaded waste package from the waste package positioning cell (1013) to the main transfer room (1003). Within the main transfer room, the waste package is surveyed for radiological contamination by using a wall-mounted, remotely operated manipulator. The waste package crane engages the waste package lower trunnions in the waste package tilting machine and tilts the closed waste package to a horizontal position on an emplacement pallet. The waste package collar removal machine then removes the waste package trunnion collars. Finally, the waste package with its emplacement pallet is loaded into the shielded waste package transporter.

Waste packages lifting design is by the attached trunnion collars only. During loadout operations, the trunnion collars are removed and the waste package must be lifted and moved by handling the emplacement pallet.

Major equipment used by the system inside these rooms/areas/cells include:

- Main transfer room crane

- WP/Cask/MSC lifting yoke

- Closure transfer trolley 
- Waste package turntable

- Waste package tilting machine

- Trunnion collar removal machine

- Waste package survey station

- Waste package pallet lifting yoke

- Manipulators

- Tools for maintenance.

The main transfer room crane is part of the cask/MSC/WP preparation system.

Waste Package Survey Station-The waste package contamination survey is performed at the waste package survey station. The waste package survey station contains a wall mounted robotic arm on a vertical mast that travels up and down and provides coverage to the entire length of the waste package as it is rotated. This operation can be observed from the main transfer operating gallery (1015) through a shield window that provides direct view of the waste package. A wall mounted smear sample transfer station transfers smear samples from the main transfer room (1003) to the main transfer operating gallery (1015) where smear counting equipment is located. The smear sample transfer station also transfers clean smear pads into the main transfer room (1003) for use. The waste package survey station is non ITS.

The waste package survey station is located between the waste package positioning cell (1013) and the waste package tilting machine. A waste package is transferred to the waste package survey area from the waste package trolley after waste package closure operations have been completed. The waste package transfer is performed by the 200-ton main transfer room crane. The waste package is lifted in front of the shield window and rotated at a slow rpm while a robotic manipulator loaded with a sample pad is held against the waste package surface. Samples are taken and transferred to the main transfer operating gallery (1015) for counting and recording. The robotic manipulator is capable of reaching the entire surface of the waste package including the top and bottom areas.

The waste package survey station is operated from a local control station in the main transfer operating gallery (1015). Operations are viewed through shield windows and closed circuit television cameras that are installed in the cell. Waste package survey station operations are also monitored remotely at consoles in the Central Control Center.

WP/Cask/MSC Lifting Yoke-The WP/Cask/MSC lifting yoke serves as the lifting interface between the loaded waste package and the main transfer room crane in the FHF main transfer room (1003). The lifting yoke is classified as ITS, see Table 2-1, because it is part of the crane assembly that is relied on to minimize the probability of a load drop to less than $1 \times 10^{-5}$ drops/transfer. The WP/Cask/MSC lifting yoke is designed to remain intact and not drop a load during a DBGM-2 seismic event. The waste package lifting yoke design incorporates features so that it will not cause a breach of the waste package if dropped onto the inner lid or from the maximum possible height.

The WP/Cask/MSC lifting yoke has a beam that supports two lifting arms, which are on opposite sides of the beam, and connects to the waste package and canister handling crane pulley block. The yoke structure is fitted with a motorized center of gravity adjustment device. A motor- 
driven assembly adjusts the arms to engage the waste package trunnions. The waste package lifting yoke arms are interchangeable. A motorized jack actuates a locking mechanism on each arm to secure the yoke to the waste package. The yoke design is such that it will have a failure rate of less than or equal to $1 \times 10^{-5}$ drops/transfer for lifting a waste package containing $\mathrm{SNF} / \mathrm{HLW}$.

Interfaces between the WP/Cask/MSC lifting yoke and other facility systems include the basic structural connection between the yoke beam and the main transfer room crane pulley block. Additional interfaces include the structural interface between the yoke lifting arms and the waste package trunnions and the electrical interface between the lifting arm motor drive and the electrical power system.

Materials of structural components are suitable for the purpose for which the material is used and comply with applicable codes and standards.

The lifting arm motor drive is operated from the local control consoles that operate the main transfer room crane.

The WP/Cask/MSC lifting yoke contacts waste packages, transportation casks, and loaded site-specific casks that may be contaminated. Therefore, the yoke is designed and manufactured to limit the retention of radiological contamination and to facilitate decontamination.

The rated capacity of the WP/Cask/MSC lifting yoke is specified to envelope the weight of the heaviest waste package, cask, or site-specific cask plus design margins specified in ANSI N14.6-1993 [DIRS 102016]. The WP/Cask/MSC lifting yoke is maintained and tested in accordance with ANSI N14.6-1993 [DIRS 102016] and ASME B30.20-2003 [DIRS 171688].

Closure Transfer Trolley-The closure transfer trolley provides structural support for waste packages during closure operations and employs a no slap down safety function during and after a DBGM-2 seismic event (Section 3.1.1.1.20). The trolley moves waste packages from the main transfer room to the waste package positioning cell and supports the waste package during closure operations. Loaded transfer trolleys are designed to not derail or drop their load during normal operations or as the result of a collision (Section 3.1.1.1.21). In the event of a power loss, the trolley is designed to stop, retain the load, and enter a locked mode; when power is restored, operator action is required for further movement of the trolley (Section 3.1.1.1.19). The trolley rides on a rail system and is designed to secure the trolley and waste package during seismic events to preclude the possibility of a loaded trolley tipping over and breach of a cask (Section 3.1.1.1.17). The closure transfer trolley is classified as ITS, see Table 2-1.

Materials of the structural components are suitable for the purpose for which the material is used and comply with applicable codes and standards.

The closure transfer trolley drive train consists of two motors that are connected to the drive wheels through a gear reducer. One motor is used to drive the trolley and the other motor provides redundancy. The trolley speed limit is such that a collision at the speed limit will not cause the trolley to drop its load (Section 3.1.1.1.18). The design of the trolley is such that in the event of a credible fire the temperature shall not reach a level that would make it drop its load (Section 3.1.1.25). 
The closure transfer trolley contacts waste packages that are potentially contaminated. Therefore, the trolley is designed and manufactured to limit the retention of radiological contamination and to facilitate decontamination.

Pedestals and Hold-Down Devices-Pedestals are used to ensure a consistent waste package height when mounted on a trolley. The pedestal has locking devices to assure the pedestal is securely fastened to the trolley. Mounting devices on the pedestals accommodate the various designs of waste packages. The pedestals are classified as ITS and designed to prevent a tipover of their load during normal operations or during and after a DBGM-2 seismic event (Sections 3.1.1.1.17 and 3.1.1.1.24).

Hold-down devices ensure that waste packages are securely fastened to the trolley and pedestal. Trolley and pedestal connections accommodate the hold-down device used for the various designs of a waste package. Hold-down devices are classified as ITS and are designed to prevent tipover of their load during normal operations or during and after a DBGM-2 seismic event (Sections 3.1.1.1.17 and 3.1.1.1.24).

Materials of the structural components are suitable for the purpose for which the material is used and comply with applicable codes and standards.

The pedestal and hold-down devices contact waste packages that are potentially contaminated. Therefore, they are designed and manufactured to limit the retention of radiological contamination and to facilitate decontamination.

Waste Package Tilting Machine-The waste package tilting machine along with the main transfer room crane is used to tilt sealed waste packages to a horizontal position. The waste package tilting machine is classified as ITS, see Table 2-1. The design of the waste package tilting machine ensure that no drop and no slapdown safety functions are maintained during and after a DBGM-2 seismic event (Section 3.1.1.1.34). The design waste package tilting machine includes measures to prevent movement or release of the lock on waste package trunnions while the waste package is being lowered onto the emplacement pallet (Section 3.1.1.1.33). The design of the waste package tilting machine is such that an impact or collision between the waste package tilting machine and a waste package will not breach the containment of the waste package or cause it to fall off the emplacement pallet (Section 3.1.1.1.36). The engineered features include mechanical locking devices and position detectors and interlocks in the tilting machine control circuitry.

The waste package tilting machine is located in the main transfer room. Waste packages arrive at the tilting machine suspended vertically from the crane. The waste package tilting machine provides support pockets that interface with the lower waste package trunnions and keep them in position but allow rotation. The crane then lowers the upper end to position the waste package onto the emplacement pallet.

The waste package tilting machine has three active drive mechanisms. The first is the drive train, which is used to move the trolley in either direction on its track. The drive train consists of two drive motors powering two drive wheels through a transmission/reducer gearbox. The second drive mechanism is used to lock the waste package trunnions into the waste package 
tilting machine pockets. There are two independent locking systems, one on each trunnion support. Each locking system is powered by an electric motor that extends the lock bar over the trunnion. The third drive mechanism is the locking device that locks the trolley in the proper position on the track. This trolley position locking system is designed to prevent movement during and after a seismic event such that a backwards slap down could occur (Section 3.1.1.1.35). The machine interfaces with the electrical system, which provides power for the drives. On loss of power, the tilting machine is designed to maintain its position and the lock on the trunnions; on restoration of power, operator action is required for further operation. The electrical power system also provides an uninterruptible power supply for the instrumentation and control system. The instrumentation and control systems used to control the waste package loadout tilting machine has a failure rate less than or equal to $1 \times 10^{-4} /$ transfer. Should the instrumentation lose its power, it is designed to fail safe, stay in the locked mode until operator action is taken, and give accurate indication upon power restoration.

Waste package tilting machine components are constructed of materials suitable for their use and comply with applicable codes and standards.

Interfaces for the waste package tilting machine include the ties to the electrical power system, which provide power for the electric drive. The waste package tilting machine is operated from local control consoles adjacent to the main transfer room. Operations are viewed through shield windows and by using CCTV cameras that are installed in the transfer room. The tilting machine is monitored remotely at consoles in the central control center. The waste package tilting machine can only be operated from one location at a time.

The waste package tilting machine is located in a low-contamination, high-radiation area in the DTF. However, the tilting machine is provided with provisions to limit the retention of contamination and to facilitate decontamination.

Waste Package Turntable-The waste package turntable is used to lift the emplacement pallet to support the weight of the waste package and disengaging the lower waste package trunnions from the tilting machine. The turntable also rotates sealed waste packages in a horizontal position for interface with the waste package collar removal machine. The waste package turntable is classified as ITS, see Table 2-1.

The waste package turntable is designed to ensure that the turntable maintains its structural integrity during seismic events. The waste package turntable employs a no-tipover safety function during and after a DBGM-2 seismic event (Section 3.1.1.1.39). The turntable is designed not to rotate while the waste package is tilted and when the emplacement pallet is raised to accept the weight of the waste package. The waste package turntable is designed such that it will not prematurely actuate (while holding the waste package on an emplacement pallet) before disengagement of the trunnion collar removal machine (Section 3.1.1.1.37). It is also designed not to move when the trunnion collar removal machine is removing the waste package trunnion collars and when the waste package tilting machine is being disengaged and retracting from the waste package. The engineered features include mechanical locking devices and position detectors and interlocks in the turntable control circuitry. Should the instrumentation lose its power, it is designed to fail safe, stay in the locked mode until operator action is taken, and give accurate indication when power is restored. The waste package turntable is designed 
such that an impact or collision between the waste package turntable and a waste package will not breach the containment of the waste package or cause it to fall off the emplacement pallet (Section 3.1.1.1.38).

The waste package turntable allows a change of orientation of the waste package during collar removal operations. The turntable support structure is designed to support the heaviest, fully loaded waste package on its emplacement pallet in the FHF, its own weight, plus safety margins.

The turntable turning system drive motors provide rotational and vertical movement of the turntable. Motors are provided to engage and disengage the turntable locking mechanism that holds the turntable in position when aligned with the waste package tilting machine or waste package collar removal machine.

Waste Package Trunnion Collar Removal Machine-The waste package trunnion collar removal machine located in room 1003 is used to remove the top and bottom trunnion collars from loaded waste packages. The waste package trunnion collar removal machine is classified ITS, see Table 2-1. The lateral drive train, translation drive mechanism, trunnion gripping drive mechanism, and the rotation drive mechanism are ITS components. The design of the waste package trunnion collar removal machine shall be such that it will not cause the waste package to drop from the emplacement pallet during use (Section 3.1.1.1.40). The waste package trunnion collar removal machine also employs no slapdown and no breach safety functions during and after a DBGM-2 seismic event (Section 3.1.1.1.41). The waste package trunnion collar removal machine accommodates the various waste package trunnion collar sizes. The waste package trunnion collar removal machine is located in the main transfer room adjacent to the waste package turntable. It moves into position when the waste package is positioned on the turntable ready for trunnion collar removal. . The waste package trunnion collar removal machine is designed such that an impact or collision between the trunnion collar removal machine and a waste package will not breach the containment of the waste package or cause it to fall off the emplacement pallet (Section 3.1.1.1.42). The waste package trunnion collar removal machine attaches to the trunnion collar and rotates the collar to remove it. After removal of the trunnion collar, the collar is placed in a trunnion collar stand to be prepared for later reuse. The trunnion collars are decontaminated, if required, and returned to the Warehouse and Non-nuclear Receipt Facility for reuse.

The waste package trunnion collar removal machine components are constructed of materials suitable for use, and comply with applicable codes and standards. The machine interfaces with the electrical system, which provides power for the drives. On loss of power, the waste package trunnion collar removal machine is designed to stop and retain the grip on the trunnion collar; on restoration of power, operator action is required for further movement. The electrical power system also provides an uninterruptible power supply for the instrumentation and control system. Should the instrumentation lose its power, it is designed to fail safe and give proper indication upon power restoration.

Operators control and monitor the waste package trunnion collar removal machine from the Main Transfer Operating Gallery (1015) adjacent to the main transfer room. At the workstation, they observe operations on CCTV and through shield windows. Operators may also monitor the machine in the central control center. 
The waste package trunnion collar removal machine is located in a low-contamination, highradiation area in the FHF. However, the machine is provided with some provisions to limit the retention of contamination and to facilitate decontamination.

Waste Package Pallet Lifting Yoke-The waste package pallet lifting yoke serves as the lifting interface between the loaded emplacement pallet, which it engages, and the main transfer room crane. The lifting yoke is classified ITS, see Table 2-1, because it is part of the crane assembly that is relied on to minimize the probability of a load drop to less than $1 \times 10^{-5}$ drops/transfer. The waste package/pallet lifting yoke is designed for loading conditions associated with a DBGM-2 seismic event. In addition, an analysis shall demonstrate that the crane lifting yokes have sufficient seismic design margin to ensure that a "no drop" safety function is maintained for loading conditions associated with a BDBGM seismic event (Section 3.1.1.1.23). In addition, the yoke is designed so that it will not breach a waste package if dropped from the maximum possible height.

The waste package pallet lifting yoke attaches directly to the hoisting mechanism of the waste package and canister handling crane. A yoke structure supports the yoke arms and connects to the crane load block. The yoke structure is fitted with a motorized center of gravity adjustment device. The yoke arms, that engage the emplacement pallet in four locations, are controlled by a motor driven assembly to engage and disengage the emplacement pallet. The yoke design is such that it has a failure rate of less than or equal to $1 \times 10^{-5}$ drops/transfer for lifting a waste package containing SNF/HLW.

Interfaces between the waste package pallet lifting yoke and other facility systems include the basic structural connection between the yoke beam and the main transfer room crane pulley block. Additional interfaces include the structural interface between the lifting yoke lifting arms and the emplacement pallet and the electrical interface between the lifting arm motor drive and the electrical power system.

Materials of structural components are suitable for the purpose for which the material is used and comply with applicable codes and standards.

The lifting arm motor drive is operated from the local control consoles that operate the main transfer room crane.

The waste package/pallet lifting yoke is not considered potentially contaminated, but the yoke is designed and manufactured to limit the retention of radiological contamination and to facilitate decontamination. The waste package pallet lifting yoke is stored and used inside the main transfer room.

The rated capacity of the waste package/pallet lifting yoke is specified to envelope the weight of heaviest waste package and associated emplacement pallet plus design margins specified in ANSI N14.6-1993 [DIRS 102016]. The waste package/pallet lifting yoke is maintained and tested in accordance with ANSI N14.6-1993 [DIRS 102016] and ASME B30.20-2003 [DIRS 171688]. 


\subsubsection{Boundaries and Interfaces}

\subsubsection{Dry Transfer Facility}

For SNF/HLW transfer operations, the system starts with a cask or site-specific cask and waste package or site-specific cask located under a docking port ready to establish confinement with the waste transfer cell or DPC cutting/WP dry remediation cell. For a naval canister cask, the system starts with a naval canister cask located in the WP loading (navy canister)/docking ring removal cell (1051) and a waste package located in the WP loading/docking ring removal cell (1054). There is no docking of cask or waste package during naval canister transfer since the canister is assumed to be noncontaminated. The system ends with an unloaded cask or sitespecific cask returning to the cask/MSC/WP preparation system and a loaded waste package placed on a subsurface emplacement transporter or a loaded site-specific cask returning to the cask/MSC/WP preparation system.

The SNF/HLW transfer system interfaces with the cask/MSC/WP preparation system for the receipt and transfer of transportation casks, site-specific casks, and waste packages. In the DTF, transportation casks (other than naval canister casks) and site-specific casks are placed in the cask and MSC docking room (1069) or DPC docking room (1101) with the docking rings installed by the cask/MSC/WP preparation system. Waste packages are placed in a waste package docking cell $(1052,1055)$ (except for waste packages receiving naval canisters) with the docking rings installed by the cask/MSC/WP preparation system. With the exception of naval canister transfer, the first task of the SNF/HLW transfer system is to establish confinement between the inside of the cask, site-specific cask, or waste package and the transfer cell or DPC cutting/WP dry remediation cell. The cask/MSC/WP preparation system takes the cask/site-specific cask following unloading and undocking, or the loaded site-specific cask following undocking.

The SNF/HLW transfer system interfaces with transportation casks, site-specific casks, and waste package types for the size, weight, and other important parameters affecting confinement, transfer, and loadout.

The SNF/HLW transfer system interfaces with the remediation system for off-normal occurrences requiring remediation. The remediation system has one path for transportation casks/site-specific casks and another path for waste packages.

The SNF/HLW transfer system interfaces with the waste package closure system for the welding/closure of waste packages immediately following loading. After acceptance from the waste package closure system the waste packages are returned to the SNF/HLW transfer system.

The SNF/HLW transfer system interfaces with the waste package emplacement and retrieval system for the loadout of waste packages for emplacement. A sealed waste package is placed on an emplacement pallet that is loaded onto the waste package transporter. The SNF/HLW transfer system also interfaces with the waste package emplacement and retrieval system for receiving waste packages needing remediation from the subsurface emplacement.

The SNF/HLW transfer system interfaces with the electrical power system for normal power but also for uninterruptible power. The electrical power system provides an uninterruptible power 
supply to all instrumentation that would lose proper indication upon loss of normal power. Other interfaces include the digital control and management information system, radiation/radiological monitoring system, communications system, and plant services system.

System physical boundaries within the DTF are:

- Cask/site-specific cask docking

- Waste package docking

- DPC cask docking

- Remediation system

- Transporter vestibule

- Closure cells.

The DPC cutting subsystem interfaces with the:

- Cask/MSC/WP preparation system - prior to docking, the transportation cask or sitespecific cask containing a DPC is prepared for DPC transfer operations by the cask/MSC/WP preparation system.

- Dry transfer subsystem - unloads the DPC after cutting the lid off.

- Remediation system - provides the equipment used to handle the DPC in the DPC cutting and waste package dry remediation cell.

- Low-level waste management system - unloaded DPCs are placed in overpacks and | processed by the site-generated radiological waste system.

The DPC cutting subsystem interfaces with the electrical power system, digital control and management information system, radiation/radiological monitoring system, communications system, and plant services system.

The dry transfer subsystem interfaces with the:

- Cask/MSC/WP preparation system - prepares the transportation cask, site-specific cask | and waste package for waste transfer operations.

- Dual-purpose canister cutting subsystem - cuts the lid off the DPC before SNF removal | and puts the unloaded canister into an overpack for disposal.

- Waste package closure system - moves the undocked loaded waste package and trolley to a cell for docking ring removal then moves the loaded waste package to waste package closure. 
- Remediation system - remediates an off-normal transportation cask, site-specific cask, | waste package, or waste form identified during the dry transfer operation and returns it to the appropriate location and system for normal processing.

The dry transfer subsystem also interfaces with the electrical power system, digital control and management information system, radiation/radiological monitoring system, communications system, and plant services system.

The waste package loadout subsystem interfaces with the:

- Dry transfer subsystem - delivers loaded waste packages to the waste package positioning cell for closure operations.

- Waste package closure system - moves a loaded waste package and trolley to the waste package loadout subsystem.

- Remediation system - if a damaged waste package is detected, the waste package and the contained waste form is sent to the remediation system. After an off-normal waste package is remediated, it is returned to the appropriate location and system to resume normal processing.

- Emplacement and retrieval system - receives sealed, loaded waste packages from the | waste package loadout subsystem for transfer from the DTF to emplacement and delivers retrieved waste packages requiring remediation.

- Non-nuclear handling system - waste package trunnion collars are removed from the waste package prior to loading the waste package on the waste package transporter. The trunnion collars are decontaminated, if necessary, and sent to the non-nuclear handling system for reuse.

The waste package loadout subsystem interfaces with the electrical power system, digital control and management information system, radiation/radiological monitoring system, communications system, and plant services system. 
The boundaries and interfaces of the DTF are described in Figure 4-1 and Table 4-1.

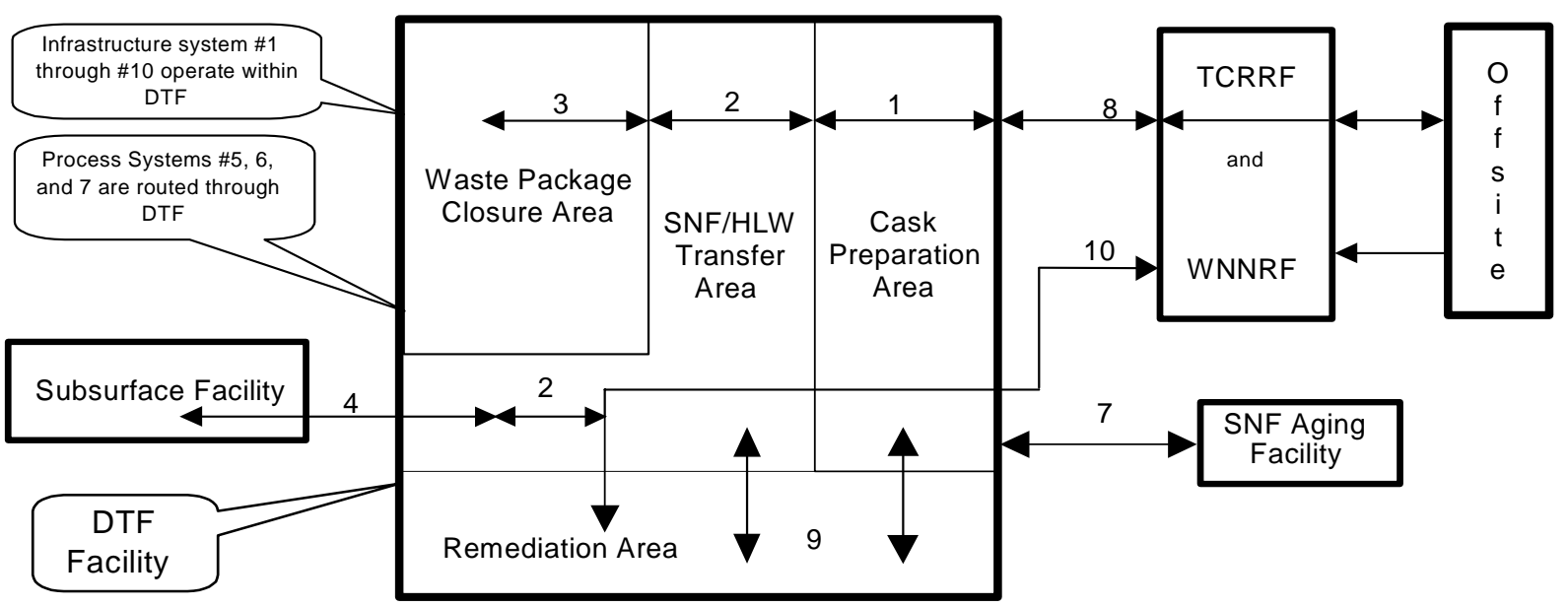

\begin{tabular}{|r|l|}
\hline$\#$ & Process Systems: \\
\hline 1 & Cask/MSC/WP Preparation System \\
2 & SNF/HLW Transfer System \\
3 & Waste Package Closure System \\
4 & Emplacement and Retrieval System (operates partially within DTF) \\
5 & DOE and Commercial Waste Package System (waste package is routed through DTF) \\
6 & Naval SNF Waste Package System (waste package is routed through DTF) \\
7 & SNF Aging System (operates partially within DTF. Site-specific casks are routed through DTF. \\
8 & Transportation Cask Receipt and Return System (transports casks and waste packages) \\
9 & Remediation Area \\
10 & Non - Nuclear Handling System (return of waste package trunnion collars) \\
\hline \hline WNNRF = Warehouse and Non-Nuclear Receipt Facility \\
TCRRF = Transportation Cask Receipt and Return Facility \\
\hline
\end{tabular}

Figure 4-1. Key Dry Transfer Facility System Boundaries 
Table 4-1. Description of Key Dry Transfer Facility System Interfaces

\begin{tabular}{|c|c|c|}
\hline $\begin{array}{c}\text { Systems Operating } \\
\text { within DTF }\end{array}$ & $\begin{array}{c}\text { Inputs } \\
\text { (SNF/HLW Transfer System to } \\
\text { Interfacing Systems) }\end{array}$ & $\begin{array}{c}\text { Outputs } \\
\text { (Interfacing Systems to } \\
\text { SNF/HLW Transfer System) }\end{array}$ \\
\hline $\begin{array}{l}\text { Cask/MSC/WP } \\
\text { Preparation }\end{array}$ & $\begin{array}{l}\text { Loaded/unloaded site-specific casks with } \\
\text { aged SNF positioned for SNF/HLW } \\
\text { transfer }\end{array}$ & $\begin{array}{l}\text { Loaded/unloaded site-specific casks ready } \\
\text { to be closed for SNF aging }\end{array}$ \\
\hline $\begin{array}{l}\text { Cask/MSC/WP } \\
\text { Preparation }\end{array}$ & $\begin{array}{l}\text { Loaded transportation casks/site-specific } \\
\text { casks positioned for SNF/HLW transfer }\end{array}$ & $\begin{array}{l}\text { Unloaded transportation casks/site-specific } \\
\text { casks ready for cask restoration }\end{array}$ \\
\hline $\begin{array}{l}\text { Cask/MSC/WP } \\
\text { Preparation }\end{array}$ & $\begin{array}{l}\text { Empty overpacks positioned for transfer of } \\
\text { DPC carcasses }\end{array}$ & $\begin{array}{l}\text { Overpack loaded with DPC carcasses ready } \\
\text { for removal from the facility }\end{array}$ \\
\hline $\begin{array}{l}\text { Cask/MSC/WP } \\
\text { Preparation }\end{array}$ & Loaded naval transportation casks & Unloaded naval transportation casks \\
\hline $\begin{array}{l}\text { Cask/MSC/WP } \\
\text { Preparation }\end{array}$ & $\begin{array}{l}\text { Empty waste packages positioned for } \\
\text { SNF/HLW transfer }\end{array}$ & \\
\hline $\begin{array}{l}\text { Cask/MSC/WP } \\
\text { Preparation }\end{array}$ & $\begin{array}{l}\text { Empty site-specific casks positioned for } \\
\text { SNF/HLW transfer }\end{array}$ & \\
\hline $\begin{array}{l}\text { Waste Package } \\
\text { Closure }\end{array}$ & $\begin{array}{l}\text { Closed waste packages ready for staging } \\
\text { or surveying and waste package loadout }\end{array}$ & $\begin{array}{l}\text { Loaded waste packages with inner lid in } \\
\text { place ready for waste package closure }\end{array}$ \\
\hline $\begin{array}{l}\text { Emplacement and } \\
\text { Retrieval System }\end{array}$ & $\begin{array}{l}\text { Retrieved or sealed waste packages } \\
\text { required to be remediated }\end{array}$ & $\begin{array}{l}\text { Sealed waste packages and pallets ready } \\
\text { for emplacement }\end{array}$ \\
\hline Remediation & $\begin{array}{l}\text { Open waste packages ready for transfer } \\
\text { of contents }\end{array}$ & Remediated waste packages \\
\hline Non-nuclear Handling & & $\begin{array}{l}\text { Waste package trunnion collars received for } \\
\text { reuse }\end{array}$ \\
\hline
\end{tabular}

\subsubsection{Canister Handling Facility}

For SNF/HLW canister transfer operations, the system starts with a cask or site-specific cask and waste package or site-specific cask located in their respective pits. The system ends with an unloaded cask or site-specific cask returning to the cask/MSC/WP preparation system and a loaded waste package transferred to the emplacement and retrieval system and placed on the waste package transporter or a loaded site-specific cask returning to the cask/MSC/WP preparation system.

The SNF/HLW transfer system interfaces with the cask/MSC/WP preparation system for the receipt and transfer of transportation casks, site-specific casks, and waste packages. Transportation casks, site-specific casks, and waste packages are placed in their respective pits by the cask/MSC/WP preparation system. The cask/MSC/WP preparation system removes the unloaded cask/site-specific cask or loaded site-specific cask.

The system interfaces with transportation casks, site-specific casks, and waste packages for the size, weight, and other important parameters affecting confinement, transfer, and loadout.

The SNF/HLW transfer system interfaces with the cask receipt and return system for off-normal cask/site-specific cask occurrences requiring remediation. 
The SNF/HLW transfer system interfaces with the waste package closure system for the welding/closure of all waste packages immediately following loading. After acceptance from the waste package closure system the waste packages are taken to the canister transfer cell (1033).

The SNF/HLW transfer system interfaces with the waste package emplacement and retrieval system for the loadout of waste packages for emplacement. A sealed waste package is placed on an emplacement pallet that is loaded onto the waste package transporter.

The SNF/HLW transfer system interfaces with the electrical power system for normal power but also for uninterruptible power. The electrical power system provides an uninterruptible power supply to all instrumentation that would lose proper indication upon loss of normal power. Other interfaces include the digital control and management information system, radiation/radiological monitoring system, communications system, and plant services system.

System physical boundaries within the CHF are:

- Canister transfer cell

- Cask preparation pit

- MSC/WP loading pit

- MSC/WP loading pit

- Canister staging pit

- Waste package positioning cells A and B.

The dry transfer subsystem interfaces with the:

- Cask/MSC/WP preparation system - receives transportation casks, site-specific casks, | and waste packages from this system. The dry transfer subsystem makes available unloaded casks and loaded or unloaded site-specific casks to this system. The dry transfer subsystem uses the waste package and canister handling crane for process operations.

- Waste package closure system - delivers loaded waste packages to the waste package | positioning cells for closure operations.

The dry transfer subsystem also interfaces with the electrical power system, the digital control and management information system, the radiation and radiological monitoring system, the communication system, and the plant services system.

The waste package loadout subsystem interfaces with the:

- Waste package closure system - receives sealed, loaded waste packages from the waste | package closure system.

- Emplacement and retrieval system - moves sealed waste packages loaded on | emplacement pallets to the waste package transporter for emplacement. 
The waste package loadout subsystem also interfaces with the electrical power system, digital control and management information system, radiation and radiological monitoring system, communication system, and plant services system.

The boundaries and interfaces of the CHF are shown in Figure 4-2 and Table 4-2.

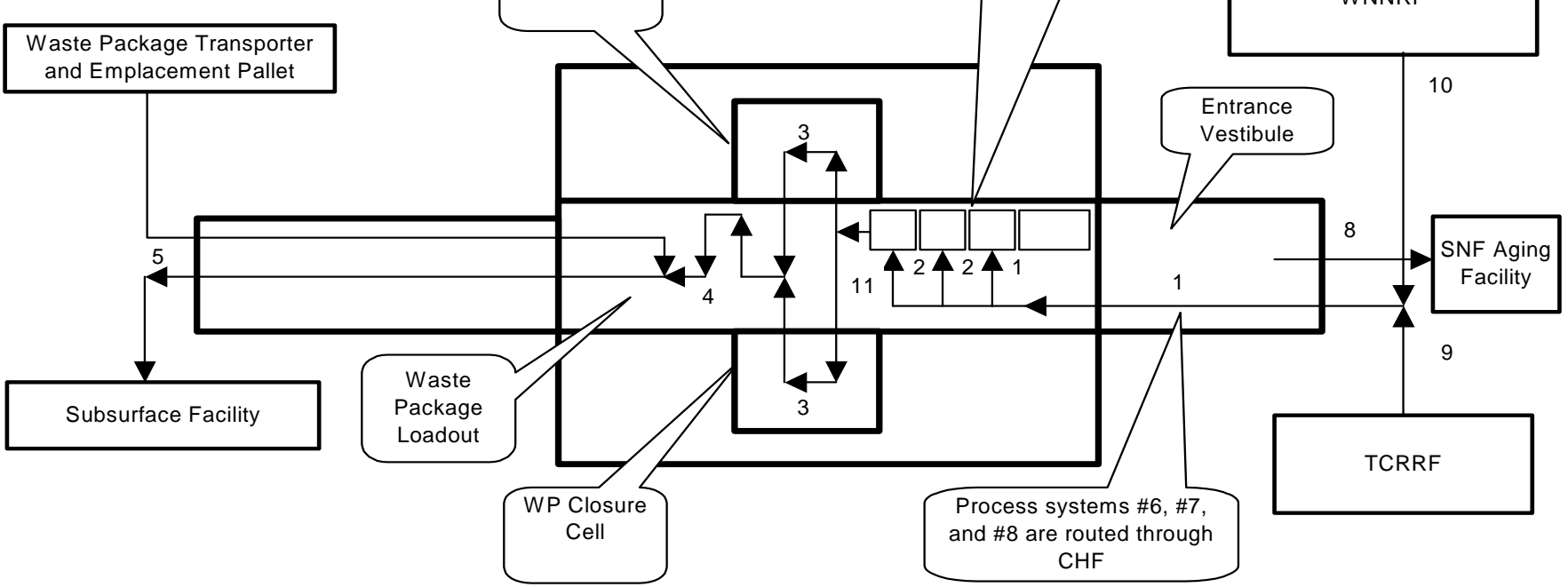

$1=$ Cask/MSC/WP Preparation System

2 = SNF/HLW Transfer System

$3=$ Waste Package Closure System

$4=$ Waste Package Loadout Subsystem (includes waste package survey)

$5=$ Emplacement and Retrieval System (operates partially within CHF)

$6=\mathrm{DOE}$ and Commercial Waste Package System (waste package is routed through $\mathrm{CHF}$ )

$7=$ Navy SNF Waste Package System (waste package is routed through CHF)

8 = SNF Aging System (site-specific casks are routed through CHF) (cask transporters operate external to CHF)

9 = Transportation Cask Receipt \& Return System

$10=$ Non-Nuclear Handling System

11 = Remediation System (minor remediation activities performed)

WNNRF $=$ Warehouse and Non-Nuclear Receipt Facility

TCRRF = Transportation Cask Receipt and Return Facility

Figure 4-2 Key Canister Handling Facility System Boundaries 
Table 4-2. Description of Key Canister Handling Facility System Interfaces

\begin{tabular}{|c|c|c|}
\hline $\begin{array}{l}\text { Systems Operating } \\
\text { within CHF }\end{array}$ & $\begin{array}{l}\text { Inputs } \\
\text { (SNF/HLW Transfer System to } \\
\text { Interfacing Systems) }\end{array}$ & $\begin{array}{c}\text { Outputs } \\
\text { (Interfacing Systems to } \\
\text { SNF/HLW Transfer System) }\end{array}$ \\
\hline $\begin{array}{l}\text { Cask/MSC/WP } \\
\text { Preparation }\end{array}$ & $\begin{array}{l}\text { Loaded transportation casks with } \\
\text { commercial DPCs or DOE SNF/HLW } \\
\text { canisters positioned for canister transfer }\end{array}$ & $\begin{array}{l}\text { Unloaded transportation casks ready for cask } \\
\text { restoration }\end{array}$ \\
\hline $\begin{array}{l}\text { Cask/MSC/WP } \\
\text { Preparation }\end{array}$ & $\begin{array}{l}\text { Loaded transportation casks with } \\
\text { commercial DPCs positioned for } \\
\text { canister transfer }\end{array}$ & $\begin{array}{l}\text { Loaded site-specific casks ready to be closed } \\
\text { for SNF aging }\end{array}$ \\
\hline $\begin{array}{l}\text { Cask/MSC/WP } \\
\text { Preparation }\end{array}$ & Loaded naval transportation casks & Unloaded naval transportation casks \\
\hline $\begin{array}{l}\text { Cask/MSC/WP } \\
\text { Preparation }\end{array}$ & $\begin{array}{l}\text { Empty waste packages positioned for } \\
\text { SNF/HLW canister transfer }\end{array}$ & \\
\hline $\begin{array}{l}\text { Cask/MSC/WP } \\
\text { Preparation }\end{array}$ & $\begin{array}{l}\text { Unloaded or empty site-specific casks } \\
\text { positioned for SNF/HLW canister } \\
\text { transfer }\end{array}$ & \\
\hline $\begin{array}{l}\text { Waste Package } \\
\text { Closure }\end{array}$ & $\begin{array}{l}\text { Loaded waste packages with inner lid in } \\
\text { place positioned on WP closure trolley }\end{array}$ & $\begin{array}{l}\text { Sealed waste package ready for survey and } \\
\text { inspection }\end{array}$ \\
\hline $\begin{array}{l}\text { Emplacement and } \\
\text { Retrieval }\end{array}$ & $\begin{array}{l}\text { Emplacement pallet ready to receive } \\
\text { sealed waste package }\end{array}$ & $\begin{array}{l}\text { Sealed waste package and emplacement } \\
\text { pallet ready for loading onto waste package } \\
\text { transporter }\end{array}$ \\
\hline Remediation & $\begin{array}{l}\text { Waste packages, transportation casks } \\
\text { and site-specific casks ready for } \\
\text { remediation }\end{array}$ & \\
\hline
\end{tabular}

\subsubsection{Fuel Handling Facility}

For SNF/HLW transfer operations, the system starts with a cask or site-specific cask and waste package or site-specific cask located in their respective transfer bays. The system ends with an unloaded cask or site-specific cask returning to the cask/MSC/WP preparation system and a loaded waste package placed on the waste package transporter or a loaded site-specific cask being sent to SNF aging.

The SNF/HLW transfer system interfaces with the cask receipt and return system, SNF aging system, and non-nuclear handling system. Transportation casks, site-specific casks, and waste packages are placed in their respective transfer bays. Unloaded transportation casks are returned to the cask receipt and return system; loaded site-specific casks are sent to SNF aging; and loaded waste packages are placed in a subsurface transporter for emplacement.

The system interfaces with transportation casks, site-specific casks, and waste packages for the size, weight, and other important parameters affecting confinement, transfer, and loadout.

The SNF/HLW transfer system interfaces with the cask receipt and return system or the SNF aging system for off-normal events requiring remediation that cannot be resolved in the FHF.

The SNF/HLW transfer system interfaces with the electrical power system for normal power but also for uninterruptible power. The electrical power system provides an uninterruptible power supply to all instrumentation that would lose proper indication upon loss of normal power. Other 
interfaces include the digital control and management information system, radiation/radiological monitoring system, communications system, and plant services system.

System physical boundaries within the FHF are:

- Main transfer room

- Preparation room

- Fuel transfer bay \#1

- Fuel transfer bay \#2

- Fuel transfer bay \#3

- Waste package positioning cell

- Fuel transfer room.

The dry transfer subsystem interfaces with the:

- Cask/MSC/WP preparation system - the dry transfer subsystem receives transportation casks, site-specific casks, and waste packages from the cask/MSC/WP preparation system. The dry transfer subsystem makes available unloaded casks and loaded or unloaded site-specific casks to this system. The dry transfer subsystem uses the main transfer room crane for process operations.

- Waste package closure system - the dry transfer subsystem delivers loaded waste | packages to the waste package positioning cell for closure operations.

The dry transfer subsystem also interfaces with the electrical power system, the digital control and management information system, the radiation and radiological monitoring system, the communication system, and the plant services system.

The waste package loadout subsystem interfaces with the:

- Waste package closure system - the waste package loadout subsystem receives sealed, loaded waste packages from the waste package closure system.

- Emplacement and retrieval system - the waste package loadout subsystem moves sealed waste packages loaded on emplacement pallets to the waste package transporter for emplacement.

The waste package loadout subsystem also interfaces with the electrical power system, digital control and management information system, radiation and radiological monitoring system, communication system, and plant services system. 
The boundaries and interfaces of the FHF are shown in Figure 4-3 and Table 4-3.
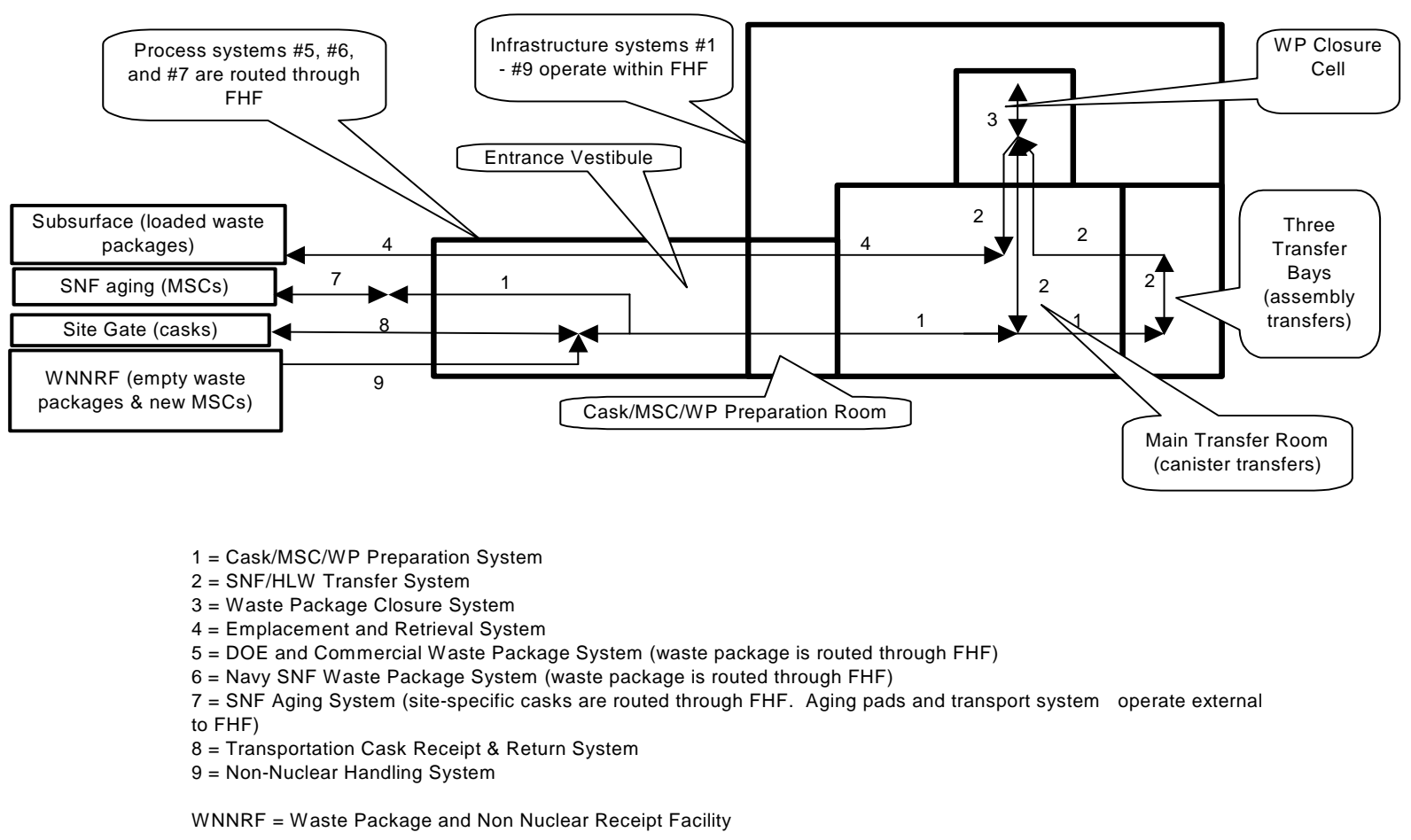

Figure 4-3 Key Fuel Handling Facility System Boundaries

Table 4-3. Description of Key Fuel Handling Facility System Interfaces

\begin{tabular}{|c|c|c|}
\hline $\begin{array}{c}\text { Systems Operating } \\
\text { within FHF }\end{array}$ & $\begin{array}{c}\text { Inputs } \\
\text { (SNF/HLW Transfer System to } \\
\text { Interfacing Systems) }\end{array}$ & $\begin{array}{c}\text { Outputs } \\
\text { (Interfacing Systems to } \\
\text { SNF/HLW Transfer System) }\end{array}$ \\
\hline $\begin{array}{l}\text { Cask/MSC/WP } \\
\text { Preparation }\end{array}$ & $\begin{array}{l}\text { Loaded site-specific casks with aged } \\
\text { SNF positioned for SNF/HLW transfer }\end{array}$ & $\begin{array}{l}\text { Unloaded site-specific casks ready to be } \\
\text { closed for SNF aging }\end{array}$ \\
\hline $\begin{array}{l}\text { Cask/MSC/WP } \\
\text { Preparation }\end{array}$ & $\begin{array}{l}\text { Loaded transportation casks/site- } \\
\text { specific casks positioned for SNF/HLW } \\
\text { transfer }\end{array}$ & $\begin{array}{l}\text { Unloaded transportation casks/site-specific } \\
\text { casks }\end{array}$ \\
\hline $\begin{array}{l}\text { Cask/MSC/WP } \\
\text { Preparation }\end{array}$ & Loaded naval transportation casks & Unloaded naval transportation casks \\
\hline $\begin{array}{l}\text { Cask/MSC/WP } \\
\text { Preparation }\end{array}$ & $\begin{array}{l}\text { Empty waste packages positioned for } \\
\text { SNF/HLW transfer }\end{array}$ & \\
\hline $\begin{array}{l}\text { Cask/MSC/WP } \\
\text { Preparation }\end{array}$ & $\begin{array}{l}\text { Unloaded site-specific casks positioned } \\
\text { for SNF/HLW transfer }\end{array}$ & \\
\hline $\begin{array}{l}\text { Waste Package } \\
\text { Closure }\end{array}$ & $\begin{array}{l}\text { Closed waste packages ready for } \\
\text { surveying and emplacement loadout }\end{array}$ & $\begin{array}{l}\text { Loaded waste packages with inner lid in place } \\
\text { ready for waste package closure }\end{array}$ \\
\hline $\begin{array}{l}\text { Emplacement and } \\
\text { Retrieval System }\end{array}$ & & $\begin{array}{l}\text { Sealed waste package and pallet ready for } \\
\text { loading onto waste package transporter }\end{array}$ \\
\hline Non-nuclear Handling & & Used waste package trunnion collars for reuse \\
\hline SNF Aging & $\begin{array}{l}\text { Loaded sealed site-specific cask for } \\
\text { transfer to waste package }\end{array}$ & $\begin{array}{l}\text { Loaded sealed site-specific cask for SNF } \\
\text { aging }\end{array}$ \\
\hline
\end{tabular}




\subsubsection{Physical Location and Layout}

\subsubsection{Dry Transfer Facility}

The SNF/HLW transfer system within the DTF includes the following cells, rooms or areas:

- Cask and MSC docking room (1069)

- DPC docking room (1101)

- DPC cutting/waste package dry remediation cell (1097)

- Waste package docking cells $(1052,1055)$

- SNF and canister staging cell (1050)

- Waste transfer cell (2048)

- Waste package loading/docking ring removal cell (1054)

- Waste package loading (navy canister)/docking ring removal cell (1051)

- Waste package handling and staging cell (1044)

- Waste package/trolley decontamination room (1094)

- Waste package loadout cell (1088)

- Waste package transporter vestibule (1087).

Locations of major equipment within the areas listed above are shown on the general arrangement drawings listed in Appendix B.

\subsubsection{Canister Handling Facility}

The SNF/HLW transfer system within the CHF includes the following cells or areas:

- Canister transfer cell (1033)

- Cask preparation pit (P002)

- MSC/WP loading pit (P004)

- Canister staging pit (P001)

- $\mathrm{MSC} / \mathrm{WP}$ loading pit (P003)

- Waste package survey area (1033)

- Collar removal/tilting area (1033)

- Exit vestibule (1031).

Locations of major equipment within the areas listed above are shown on the general arrangement drawings listed in Appendix B.

\subsubsection{Fuel Handling Facility}

The SNF/HLW transfer system within the FHF includes the following rooms or areas:

- Entrance vestibule (1001)

- Preparation room (1002)

- Main transfer room (1003)

- Fuel transfer bay \#1 (1004) 
- Fuel transfer bay \#2 (1005)

- Fuel transfer bay \#3 (1006)

- Waste package positioning cell (1013).

- Main transfer operating gallery (1015)

- Fuel transfer room (2001)

- Fuel transfer operating gallery (2002)

Locations of major equipment within the areas listed above are shown on the general arrangement drawings listed in Appendix B.

\subsubsection{Principles of Operation}

The operating philosophy and principals of operation presented in this section are based on the YMP technical requirements and bases, and experience and lessons learned in the design, construction, and operation of existing nuclear processing facilities that perform similar functions.

Based on ALARA requirements, local and manual operations are performed either hands-on, when the worker can stay close or in direct contact with the components, or with master/slave manipulator work stations, when the worker needs to be isolated from the radiation sources. Hands-on or contact operations may require the implementation of local radiation shielding or the use of engineered tools if required by ALARA assessments and radiological work permits.

All SNF/HLW transfer operations, including bare fuel, casks, canisters, and waste packages, are remote. They are controlled by operators at local control stations near the equipment and are monitored in a central control room. Some operations may be carried out manually, using remote tools and master/slave manipulators through the shielded walls.

\subsubsection{Dry Transfer Facility}

The DTF is a facility with a high potential for contamination in the waste transfer cells but a low potential for contamination in other areas, such as the waste package loadout room and the cask preparation and transfer rooms. When radiation sources are not present or are shielded, personnel may enter the waste package loadout room. During such times, some operations will be performed directly on the equipment. Some examples of the types of operations to be performed are as follows: grapple changes, lifting beam changes, tilting machine setup, and lifting beam setup.

\subsubsection{Canister Handling Facility}

The CHF is a facility with a low potential for contamination. When radiation sources are not present or are shielded, personnel may enter the operating areas of the facility. During such times, some operations will be performed directly on the equipment. Some examples of the types of operations to be performed are as follows: grapple changes, lifting beam changes, tilting machine setup, lifting beam setup, and cask preparation. 


\subsubsection{Fuel Handling Facility}

The FHF is a facility with a high potential for contamination in the fuel transfer room but a low potential for contamination in the main transfer room. When radiation sources are not present or are shielded, personnel may enter the main transfer room. During such times, some operations will be performed directly on the equipment. Some examples of the types of operations to be performed are as follows: grapple changes, lifting beam changes, tilting machine setup, lifting beam setup, and cask preparation.

\subsubsection{System Reliability Features}

System reliability features such as preferred failure modes or fail safe positions, as well as redundant subsystems or components, will continue to be developed as the design progresses. Such features will be incorporated into the design based on standard industry practices and reliability analyses such as fault trees and failure mode and effects analysis (FMEA) design analysis of critical equipment and components.

Features and requirements resulting from preliminary analysis for the main critical equipment, such as waste handling cranes, waste package trolleys, and docking stations, are listed in Section 3.5.3.

\subsubsection{System Control Features}

The description, functions, and requirements for the control systems, and part of the digital control and management information system and are identified in the system design documentation.

There is one central control center for the repository site. Monitoring and supervisory control are provided on consoles in the central control center.

Monitoring and full control are provided by control interfaces local to the operation. Monitoring may include the use of CCTV to view and supervise operations.

In general, the control of the system is divided into two major control modes:

- Automatic Control Mode-Under automatic control mode, operating actions and cycles of operations occur without direct action from the operator. However, in the automatic control mode, operator actions may be necessary for certain process steps to occur.

- Manual Control Mode-Under manual control mode, some actions may be performed manually in addition to the automatic control, but only within a certain operating range.

Operators control and monitor the operations from a local workstation adjacent to the working cell. At the workstation, they observe operations on CCTV or through shield windows.

The location of the control room and the local control stations and the definition of control modes (automatic or manual) have yet to be defined according to the overall control philosophy of the plant. 
Additional information will be provided as part of the detailed design.

\subsection{OPERATIONS}

\subsubsection{Initial Configuration (Prestartup)}

Key steps to be performed to verify the system is in proper configuration for operation prior to startup will be developed in a future revision.

In general, for much of the mechanical handling equipment, the facility technical specification requirements must be followed in addition to vendor operating and maintenance manuals. Operator training qualification records must also be verified as part of prestartup. References to applicable procedures will be provided as the design progresses. Examples include:

- Checking maintenance records to assure testing and inspection have been performed in accordance with the procedures

- Ensuring completion of maintenance of SSCs

- Verifying that SSCs were returned to service properly following maintenance.

\subsubsection{System Startup}

A summary of key steps required to prepare the system for normal operations including sequencing, timing, and confirmation that the system is ready for normal operation will be developed in a future revision.

In general, for the mechanical handling equipment, each piece of equipment has an initial configuration position. Specific procedures must be followed for each piece of equipment prior to it being placed in initial configuration position. References to applicable procedures will be provided as the design progresses.

Examples include ensuring all interlocks are satisfied, all instrumentation is operational, as applicable, and power is available to the system. Additionally, the operations shift supervisor or foreman must have the proper procedures, production plans, and schedules in hand. Different system startup steps may be required depending on the operation method (automatic or manual control). These steps shall be performed prior to changing control methods in accordance with the procedures.

Authorization for system startup can take place only after completion of the above steps.

\subsubsection{Normal Operations}

\subsubsection{Dry Transfer Facility}

Normal operations begin after confirmation that the system is ready for startup. For further details, see radiation classifications and general arrangements drawings listed in Appendix B. 


\subsection{Dual-Purpose Canister Cutting Subsystem}

The DPC cutting subsystem performs the following normal operations:

- DPC cask docking

- Transfer of DPC

- DPC sampling/venting

- DPC cutting

- DPC unloading

- DPC removal.

The DPC cutting subsystem process begins with the docking of the DPC transportation cask to the DPC cutting/waste package dry remediation cell and removal of the docking port plug

The waste package remediation crane transfers the DPC to the DPC cutting station. The interior of the DPC is accessed, sampled, and vented. The cutting machine is positioned on the DPC. The machine tool cuts through the DPC just below the lid into the canister wall, generating little or no secondary waste (TBD).

The severed lid is then raised just high enough for a power shear to reach in and cut off the long drainpipe used during loading of the DPC. The severed drainpipe is allowed to simply drop back down into its cavity in the fuel basket. The opened DPC is moved to an unloading port and aligned for SNF transfer by the SFTM.

When complete, the severed DPC lid is replaced, and the unloaded DPC is transferred to an overpack docked to the DPC docking station. The overpack is then handled by the low-level waste management system.

Key steps for each operation are as follows:

\subsection{Transfer of Dual-Purpose Canister}

- Confirm proper placement of cask under the DPC docking port (DPC docking room, 1101)

- Dock and open the cask

- Install lifting features onto DPC (design TBD)

- Lift the DPC out of the cask using the 100-ton waste package remediation crane

- Close and undock the cask

- Await transfer of cask back to cask/MSC/WP preparation system. 


\subsection{Dual-Purpose Canister Cutting}

- Position DPC on cutting machine base using the 100-ton waste package remediation crane (DPC cutting/WP dry remediation cell, 1097)

- Sample and vent the DPC interior atmosphere

- Perform DPC cutting operations

- Using DPC cutting station, raise severed DPC lid and use power shear to cut DPC drain pipe attached to DPC lid

- Position the DPC on the waste package/DPC trolley with the 100-ton waste package remediation crane

- Move the waste package/DPC trolley to the DPC/waste package unload location (DPC cutting/WP dry remediation cell, 1097).

\subsection{Dual-Purpose Canister Unloading}

Transfer contents of DPC using the dry transfer subsystem.

\subsection{Dual-Purpose Canister Removal}

- Move the WP/DPC trolley with the unloaded DPC, back to its initial position (DPC cutting/WP dry remediation cell, 1097)

- Place lid in DPC

- Transfer the unloaded DPC with the 100-ton waste package remediation crane into an overpack docked in the DPC docking room (1101)

- Close overpack and prepare for loadout as low-level radioactive waste.

\subsection{Dry Transfer Subsystem}

The dry transfer subsystem performs the following normal operations:

- Transfer from cask/site-specific cask to waste package or to staging

- Transfer from DPC to waste package or to staging

- Transfer from cask to site-specific cask

- Transfer from staging to waste package or site-specific cask

- Transfer loaded waste package to the WP loading/docking ring removal cell (1054) or WP loading (navy canister)/docking ring removal cell (1051) 
- Perform waste package restoration steps (i.e., removal of docking ring)

- Decontaminate docking ring if necessary and return docking ring to docking ring storage area

- Transfer the loaded waste package out of the waste package loading/docking ring removal cell $(1054,1051)$, and await transfer to waste package trolley (trolley to the waste package positioning cell, 1039, 1040, 1041) for waste package closure operations

- Transfer the loaded waste package from the waste package trolley (from the WP loading (navy canister)/docking ring removal cell, 1051) to the waste package trolley (in waste package handling and staging cell, 1044) using the 100-ton waste package handling crane

- Transfer waste package on trolley to closure cell.

The dry transfer subsystem process begins with the docking of the transportation cask or sitespecific cask to the waste transfer cell. This process includes establishing the confinement boundary and removing the docking port plugs and associated cask/MSC/WP lids. The contents are then verified, with a camera mapping the SNF/HLW. For commercial SNF assemblies, the appropriate grapples are selected for the SFTM. The operator indexes the SFTM to identify the unloading position, the item to be transferred and the end position, and then initiates the automatic transfer of the SNF assembly to its destination. This process including SNF assembly identification, operator validation steps, and possible burnup verification is repeated for each SNF assembly. This process would also be used to transfer assemblies from a staging rack to a waste package or site-specific cask. For transfer of SNF from an opened DPC, the process is similar; access is through the hatch between the waste transfer cell and the DPC cutting and waste package dry remediation cell. Operators use CCTV or direct observation through shielded windows to control manual and power manipulators, overhead bridge cranes, SNF transfer machines and other remote equipment to perform SNF and HLW transfer functions.

For transportation casks or site-specific casks containing DOE SNF, HLW canisters, the identification of the canister is verified. The canister and HLW handling crane transfers the canister to a waste package, site-specific cask, or staging rack. This process would also be used to transfer a canister from a staging rack to a waste package or site-specific cask

For naval casks containing naval canisters, the navy canister handling crane transfers the canister from the cask to the waste package.

For remediated waste packages containing SNF assemblies, the SFTM transfers the assemblies from the DPC cutting and waste package dry remediation cell through the waste transfer cell to the new waste package in the waste package docking cell. For remediated waste packages containing DOE SNF or HLW canisters or naval canisters, the canister and HLW handling crane transfers the canister from the DPC cutting and waste package dry remediation cell through the waste transfer cell to the new waste package in the waste package docking cell. 
For an unloaded cask, visual and physical checks are performed, and the cask is undocked and transferred to the cask/MSC/WP preparation system for restoration operations prior to leaving the DTF.

For a loaded waste package or site-specific cask, visual checks and record verifications are performed. Site-specific casks are undocked and returned to the cask/MSC/WP preparation system for cask restoration. For loaded waste packages, the inner lid is installed and the waste package is undocked and the trolley is moved to the waste package loading and docking ring removal cell (1051 or 1054). The waste package docking ring is removed and transferred to the docking ring storage area for decontamination and storage. The waste package trolley is moved into the waste package handling and staging cell (1044).

The waste package handling crane performs the handling activities in the waste package handling and staging cell. The crane transfers the waste package from the first trolley to one of three closure cell trolleys that moves the waste package into a waste package positioning cell, for waste package closure.

Key steps for each operation are as follows:

\subsection{Transfer from Cask/Site-Specific Cask to Waste Package or to Staging}

- Begin cask unloading operations in conjunction with loading operations

- Confirm proper placement of loaded cask under cask docking port (cask and MSC docking room, 1069)

- Perform cask docking and opening operations

- Transfer waste from cask to waste package (waste package docking cell, 1052, 1055) or to SNF and canister staging cell (1050) using the SFTM or in the case of canisters, the 70-ton canister/HLW handling crane. Visually verify identification numbers on SNF canisters prior to placement

- Verify emptiness of cask with probe for dose rate and cask characterization.

- Begin waste package loading operations (occurs simultaneously with cask unloading operations)

- Confirm proper placement of empty waste package under waste package docking port (waste package docking cell, 1052, 1055)

- Perform waste package docking and opening operations

- Transfer waste from cask or staging area to waste package using the SFTM or in the case of canisters, the 70-ton canister/HLW handling crane. 
- Perform waste package undocking operations (including placing inner lid on waste package)

- Perform cask closing and undocking operations

- Place shield plug on cask

- Await transfer of unloaded cask to the cask restoration room (1072).

\subsection{Transfer from Dual-Purpose Canister (opened) to Waste Package or to} Staging

- Begin DPC unloading operations (occurs simultaneously with waste package loading operations)

- Confirm proper placement of loaded DPC under DPC/waste package transfer hatch (DPC cutting/WP dry remediation cell, 1097)

- Open DPC/waste package transfer hatch

- Transfer SNF from DPC to waste package (waste package docking cell, 1052, 1055) or staging (SNF and canister staging cell, 1050) using the SFTM. Visually verify identification numbers on SNF prior to placement

- Verify emptiness of DPC with probe for dose rate inside cask

- Shut DPC/waste package transfer hatch.

- Begin waste package loading operations (occurs simultaneously with DPC unloading operations)

- Confirm proper placement of empty waste package under waste package docking port (waste package docking cell, 1052, 1055)

- Perform waste package docking and opening operations

- Transfer SNF from DPC or staging area to waste package using the SFTM.

- Perform waste package closing and undocking operations (place inner lid on waste package).

\subsection{Transfer from Cask (with Naval Canister) to Waste Package}

- Begin cask unloading operations (occurs simultaneously with waste package loading operations)

- Confirm proper placement of loaded cask in WP loading (navy canister)/docking ring | removal cell (1051) 
- Perform cask opening operations

- Install lifting fixture on naval canister

- Transfer naval canister from cask to waste package using the 70-ton navy canister handling crane

- Replace cask lid

- Await transfer of unloaded cask to the navy cask preparation room.

- Begin waste package loading operations (occurs simultaneously with cask unloading operations):

- Confirm proper placement of empty waste package in WP loading /docking ring | removal cell (1054)

- Perform final waste package loading preparation operations (remove waste package inner lid)

- Transfer naval canister from cask to waste package using the 70-ton navy canister handling crane

- Perform waste package operations to prepare for transfer to the waste package handling and staging cell (place inner lid on waste package).

\subsection{Transfer from Cask to Site-specific Cask}

- Similar to cask transfer to waste package, except:

- Confirm proper placement of cask under cask docking port and site-specific cask under a second cask (site-specific cask) docking port (cask and MSC docking room 1069)

- Dock and open cask and site-specific cask

- Transfer waste from cask to site-specific cask, or to/from staging if required (SNF and canister staging cell 1050), using the SFTM or the 70-ton canister/HLW handling crane. Visually verify identification numbers on SNF or canisters prior to placement

- Close and undock cask and site-specific cask

- Await transfer of cask and site-specific cask back to cask/MSC/WP preparation system (interface to cask/MSC/WP preparation system). 


\subsection{Waste Package Loadout Subsystem}

The waste package loadout subsystem performs the following normal operations:

- Waste package transfer from closure cell to waste package handling and staging cell

- Waste package staging if necessary (closed waste package)

- Waste package visual inspection

- Waste package survey and decontamination, if necessary

- Waste package loadout to the waste package transporter.

The waste package loadout subsystem handles the waste package following closure operations performed by the waste package closure system. The waste package handling crane performs the handling activities in the waste package handling and staging cell (1044).

After closure is completed, the waste package is moved back into the waste package handling and staging cell by the closure cell trolley. At this point, the waste package handling crane moves the waste package to the waste package survey station, remediation system, or the staging area.

If the waste package does not pass the closure weld inspections and is unable to be repaired in the closure cell, the crane places it on a trolley for movement to the remediation system.

If the waste package needs to be staged prior to emplacement, the crane transfers it to the staging area.

When the waste package is authorized for emplacement, the crane transfers it to the waste package survey station, where contamination surveys are performed. If it is contaminated beyond emplacement limits, the waste package is moved to the WP/trolley decontamination room (1094). Once the waste package passes the survey, the crane transfers the waste package from the survey station to the waste package trolley, which moves it to the waste package loadout cell (1088).

In the waste package loadout cell the waste package tilting machine is aligned for the type of waste package to be handled. The waste package transporter brings the emplacement pallet to the facility by the transport locomotive. The locomotive is decoupled and the transporter is then moved into the facility by the transporter positioner. The transporter bedplate extends to place the emplacement pallet on the waste package turntable. The waste package loadout handling crane lifts the waste package and places the lower trunnions into the appropriate slots of the waste package tilting machine. The waste package is tilted to a horizontal position on the emplacement pallet. The trunnion collar removal machine removes the trunnion collars. The transporter bedplate then extends to receive the waste package and emplacement pallet from the turntable, and then retracts them inside the shielded area of the transporter. After the transporter is loaded, it is moved away from the turntable by the transporter positioner. The transport locomotive is then recoupled to the transporter and both exit the facility.

The waste package loadout operations take place in a different operational area from the transfer operations. This separation allows both operations to occur simultaneously. 
The waste package loading and inspection records (including SNF/HLW inventory and location, decontamination, and closure surveys) or logs maintained by or for the system are centrally stored and available to operating staff.

Key steps for each operation are as follows:

\subsection{Waste Package Loadout Preparation}

- After closure operations (interface with waste package closure system), perform a waste | package contamination survey.

- If waste package does not pass postclosure checks, transfer the waste package to the remediation system using the 100-ton waste package handling crane and the waste package trolley to remediation (interface with remediation system), otherwise continue with process.

- If waste package is contaminated, transfer waste package to the waste package trolley leading to the WP/trolley decontamination room (1094) with the 100-ton waste package | handling crane and perform decontamination operations, then continue with process.

\subsection{Waste Package Staging}

- If necessary, stage closed waste package in a controlled manner awaiting loadout in the waste package handling and staging cell (1044)

- Stage waste package in the waste package handling and staging cell as required until emplacement is authorized.

\subsection{Waste Package Loadout to Waste Package Transporter}

- When the waste package is authorized for emplacement, prepare waste package tilting machine according to type of waste package

- Transfer the waste package to the waste package loadout cell (1088) using the 100-ton waste package loadout handling crane and the waste package trolley (to the waste package loadout cell)

- Perform waste package tilting operations with the waste package tilting machine and 100 -ton waste package loadout handling crane to place the waste package in a horizontal position on an emplacement pallet

- Remove trunnion collars with the trunnion collar removal machine

- Transfer waste package on the emplacement pallet into shielded waste package transporter

- Return waste package transporter with loaded waste package to the waste package emplacement and retrieval system. 


\subsubsection{Canister Handling Facility}

Normal operations begin after confirmation that the system is ready for startup. For further details, see radiation classifications and general arrangements drawings listed in Appendix B.

\subsection{Dry Transfer Subsystem}

The dry transfer subsystem has the following normal operational steps:

- Transfer from cask/site-specific cask to waste package or to staging

- Transfer from cask to site-specific cask

- Transfer from staging to waste package or site-specific cask.

The first step in the transfer process is to remove the transportation cask lid and place it in a stand. The transportation cask lid-lifting fixture is then replaced with the canister grapple on the 100-ton waste package and canister handling crane. The canister is lifted to within the design bases lift height and moved to a location over the waste package and lowered into the waste package. Given that a waste package configuration is different than DOE transportation casks, the contents of more than one cask would be required to fill a waste package. If a waste package is filled before a cask is emptied, the remaining DOE SNF and HLW canisters are moved to the staging pit until a new empty waste package is prepared. If the thermal conditions of a DOE SNF or HLW canister are such that the canister cannot be immediately emplaced, the above operations are performed to transfer the canister into a site-specific cask for movement to the aging system. For naval canisters, one transfer is required to load the canister into the waste package; these canisters are preloaded to meet the design basis thermal limit per waste package. Vertical DPCs are transferred to site-specific casks and moved to the aging system.

The waste package inner lid is placed back in the waste package using the 100-ton waste package and canister handling crane and appropriate grapple. The grapple is then replaced with waste package lifting yoke, the waste package trunnions are engaged, and the waste package is lifted out of the waste package pit. The waste package is placed on the pedestal located on the waste package trolley at the entrance of the waste package positioning cell. Load paths and lift height limits are implemented during these movements.

The waste package trolley is located in the canister transfer cell. Waste packages are secured on the trolley and transferred to the waste package positioning cell for waste package closure operations.

Key steps for each operation are as follows:

\subsection{Transfer from Cask/Site-specific Cask to Waste Package or to Staging}

- Begin cask unloading operations in conjunction with loading operations

- Confirm proper placement of loaded cask and empty waste package in appropriate pits

- Remove cask lid, or staging pit plug or waste package pit plug as required with waste package and canister handling crane 
- Transfer waste from cask to waste package or staging pit using the waste package and canister handling crane. Visually verify identification numbers on canisters prior to placement using CCTV

- Verify emptiness of cask with probe for cask characterization

- Replace cask lid

- Place shield plug on waste package pit or staging pit

- Await restoration and disposition of unloaded cask.

The same steps are assumed for the site-specific cask since the design of site-specific casks is not currently established.

\subsection{Transfer from Cask to Site-Specific Cask}

- Begin cask unloading operations in conjunction with loading operations

- Confirm proper placement of loaded cask and site-specific cask in appropriate pits

- Remove cask lid and site-specific cask lid with the waste package and canister-handling crane

- Transfer waste from cask to site-specific cask using the waste package and canister-handling crane. Visually verify identification numbers on canisters prior to placement

- Verify emptiness of cask with probe for cask characterization

- Replace cask lid and site-specific cask lid

- Return unloaded cask and loaded site-specific cask to cask/MSC/WP preparation system.

\subsection{Waste Package Transfer to Positioning Cell}

- Remove waste package pit plug with the waste package and canister-handling crane

- Place waste package inner lid on loaded waste package

- Lift the waste package out of its pit with the waste package and canister-handling crane and put it on the waste package trolley

- Transfer loaded waste package with the waste package trolley to waste package positioning cell 
- If waste package does not pass postclosure weld checks, open waste package (using closure system), otherwise continue with process

- After closure operations (interface with waste package closure system), transfer loaded waste package from the waste package positioning cell to the waste package survey station for contamination survey.

\subsection{Waste Package Loadout Subsystem}

The waste package loadout subsystem has the following normal operational steps:

- Waste package transfer from the closure cell

- Waste package survey

- Waste package loadout to the waste package transporter.

Before a waste package is moved out of the waste package-positioning cell, a waste package transporter with a waste package emplacement pallet is moved into the loadout area through the exit vestibule, and the shield doors on the transporter are opened. The bedplate is extended to allow access to the waste package emplacement pallet, and the pallet is moved from the transporter bedplate to the waste package turntable using the 100-ton crane and waste package and pallet lifting yoke. This yoke is then replaced with the waste package yoke and the waste package loadout subsystem is now ready to receive the waste package. The waste package trolley then moves the waste package out of the waste package-positioning cell into the loadout area so the 100-ton crane can access the waste package. The crane with the appropriate yoke is then used to lift and move the waste package to the survey area where the waste package is surveyed for surface contamination. A waste package surface contamination survey is performed using a wall-mounted, remotely operated manipulator. The crane is then used to lift the waste package and transfer it to the waste package-tilting machine and down ended to a horizontal orientation on the emplacement pallet. The waste package turntable with the pallet is then raised to make contact with the waste package and raised high enough to disengage the waste package trunnion from the tilting machine. The yoke is removed from the waste package trunnions and the tilting machine is moved away from the waste package turntable.

The turntable is then used for remote removal of the waste package trunnion collars via the trunnion collar removal machine. When the waste package is positioned on the turntable and ready for trunnion collar removal, the collar removal machine moves to align with the waste package trunnions. The machine then engages the trunnion collar and rotates the collar counter clockwise to disengage it from the waste package. After removal of the trunnion collar, the trunnion collar removal machine moves the collar away from the waste package and the trunnion collar is transferred to a collar stand by the 100-ton crane with correct grapple. The turntable rotates the waste package so the remaining trunnion collar is in position and the process is repeated. At this point, a visual inspection is performed by using a CCTV and identification is verified.

The waste package lifting yoke is then remotely replaced with the waste package/pallet lifting yoke. The 100-ton crane and lifting yoke are positioned over the waste package and emplacement pallet. The lifting fixture is used to remotely engage the emplacement pallet. The 
waste package and emplacement pallet are lifted and moved to the waste package transporter bedplate. The waste package, pallet, and bedplate are retracted into the waste package transporter, and the transporter shield doors are closed. The waste package transporter is then moved from the CHF to the subsurface for emplacement.

The following types of records or logs maintained by or for the system are centrally stored and available to operating staff:

- Waste package loading and inspection records (including SNF/HLW inventory and location, decontamination, and closure surveys)

- Waste package inspection records

- Cask inspection records

- Others.

Key steps for each operation are as follows:

- When the waste package is authorized for emplacement, prepare waste package tilting machine according to type of waste package

- Transfer loaded waste package to the canister transfer cell with the waste package trolley

- Transfer the loaded waste package to the waste package tilting machine with the waste package and canister handling crane

- Perform waste package tilting operations with the tilting machine and waste package and canister handling crane. Place the waste package in a horizontal position on the emplacement pallet

- Remove trunnion collars with the trunnion collar removal machine and turntable

- Perform visual inspection of waste package via CCTV

- Perform waste package loadout operations (i.e., place waste package, on its emplacement pallet, onto waste package transporter, then move waste package and emplacement pallet inside shielded section of waste package transporter)

- Move waste package transporter with loaded waste package to exit vestibule.

\subsubsection{Fuel Handling Facility}

Normal operations begin after confirmation that the system is ready for startup. For further details, see radiation classifications and general arrangements drawings listed in Appendix B. 


\subsection{Dry Transfer Subsystem}

The dry transfer subsystem is designed to transfer commercial SNF, DOE SNF, and DOE HLW:

- From transportation casks and site-specific casks with uncanistered waste to waste packages and site-specific casks using the spent fuel transfer machine

- From transportation casks with canistered waste to waste packages using the 200-ton main transfer room crane

- From transportation casks with commercial DPCs to site-specific casks using the 200-ton main transfer room crane.

Prior to dry transfer operations, the transportation casks, site-specific casks, or waste packages are prepared and positioned in the canister transfer station or under the applicable fuel transfer room docking port.

\subsection{Transfer from Transportation Casks (noncanistered commercial SNF)}

Transfer of commercial SNF assemblies is conducted between three transfer bays: fuel transfer bay \#1 (1004), fuel transfer bay \#2 (1005), and fuel transfer bay \#3 (1006) and the fuel transfer room (2001). When an empty waste package, or empty or unloaded site-specific cask and a loaded cask/site-specific cask are positioned for docking under a docking port, the respective port docking devices are activated. This activation lowers the port-docking device to the docking ring and establishes radiological confinement with the floor of the fuel transfer room (2001). The waste package or empty or unloaded site-specific cask inner lid is lifted into a pocket of the docking port plug. The port plug with inner lid is removed and placed in temporary storage. Similarly, the docking port plug and the loaded cask/site-specific cask inner lid are removed and placed in temporary storage. SNF waste transfer operations between a loaded cask/site-specific cask and an empty waste package (or empty or unloaded site-specific cask) may begin once the inner lids are removed and stored. Once the transfer is completed, the dose rate in the unloaded cask is monitored and the cask interior is visually inspected for remaining items.

Following completion of transfer operations, the docking port plug with the waste package inner lid attached is returned to the transfer port. The inner lid is released from the port plug and returned to the waste package. The port-docking device is disengaged and the transfer trolley is moved from the transfer bay to the main transfer room. The waste package-docking ring is removed and the waste package lifted from the transfer trolley. The transfer trolley is returned to the transfer bay. The waste package positioning cell door is opened and the closure trolley, previously prepared with the appropriate pedestal, is moved into position under the waste package. The waste package is lowered onto the closure cell trolley and moved to the waste package positioning cell.

In the main transfer room the waste package-docking ring is swipe surveyed for loose contamination. Any loose contamination is wiped clean to allow reuse of the docking ring. The docking ring is moved to its staging stand within the main transfer room. If more aggressive 
decontamination of the docking ring is required than available by FHF means, the docking ring is bagged and placed in storage for decontamination when more aggressive capabilities are established on site.

\subsection{Transfer from Transportation Casks (canistered naval SNF)}

Transfer of canistered naval SNF is conducted within the main transfer room (1003). A cask loaded with canistered naval SNF and an empty waste package is positioned with inner lids removed at the canister transfer station on the floor of the main transfer room. Canistered naval $\mathrm{SNF}$ is transferred from the loaded cask to an empty waste package. Once the transfer is completed, the dose rate in the unloaded cask is monitored and the cask interior is visually inspected for remaining items. Following completion of transfer operations to a waste package, the inner lid is returned to the waste package and the waste package is lifted from the canister transfer station to the closure trolley. The trolley is then moved into the waste package closure transfer room.

\subsection{Transfer from Transportation Casks (canistered DOE SNF [except naval SNF] or HLW)}

Transfer of DOE SNF/HLW is also conducted within the main transfer room (1003). An empty waste package, or site-specific cask and a loaded cask are positioned at the canister transfer station on the floor of the main transfer room. The waste package, or site-specific cask and cask inner lids are removed and staged within the main transfer room. Canistered DOE SNF/HLW is transferred from the loaded cask, to the empty waste package. Once the transfer is completed, the dose rate in the unloaded cask is monitored and the cask interior is visually inspected for remaining items. Following completion of transfer operations to a waste package, the inner lid is returned to the waste package, the protective collar removed, and the waste package lifted from the floor of the main transfer room to the closure trolley. The trolley is moved into waste package closure transfer room.

\subsection{Transfer from Transportation Casks with Dual-Purpose Canisters}

The only handling of DPCs in the FHF is to site-specific casks for aging. Transfer of DPCs is conducted from a transportation cask to a site-specific cask in the main transfer room (1003). The site-specific cask lids are removed and staged. The DPC is transferred from the loaded cask to the empty site-specific cask. Once the transfer is complete, the dose rate in the unloaded transportation cask is monitored and the cask interior is visually inspected for remaining items. It is anticipated that DPC transportation casks will not contain residual SNF/HLW debris, but a visual inspection will still be performed.

\subsection{Loadout Subsystem}

\subsection{Waste Package Loadout}

Once the loaded waste package is in the waste package positioning cell and the door closed for closure operations, the waste package transporter enters the main transfer room through the entrance vestibule and is positioned for waste package loading. The shield door(s) on the transporter are opened, and the bedplate with the waste package emplacement pallet is extended. 
The emplacement pallet is lifted from the transporter bedplate and placed onto the turntable located within the main transfer room and made ready to receive the closed waste package.

When the waste package is welded closed, the waste package transporter and emplacement pallet in position, and the exterior door of the preparation room closed, the door of the waste package positioning cell is opened, and the waste package is returned to the main transfer room. The waste package is moved from the closure trolley to the survey station, remotely inspected for damage and surveyed for contamination. If necessary, limited dry wipe decontamination is remotely performed to clean loose contamination from the waste package. When decontaminated, as necessary, the waste package is moved to the tilting fixture within the main transfer room and down-ended to a horizontal position onto the emplacement pallet. The turntable repositions the waste package for remote removal of trunnion collars by a collar removal machine. The collars are removed and placed into a holding rack within the main transfer room.

The emplacement pallet with waste package is lifted from the turntable, moved to the transporter, and lowered into place onto the transporter bedplate. The waste package, pallet, and transporter bedplate are retracted into the waste package transporter, the shield door(s) of the transporter are closed, and the waste package transporter is removed from FHF.

\subsection{Site-specific Cask Loadout}

After the site-specific cask has been loaded and prepared for removal the closure lid is set in place and is ready for final closure operations by the cask/MSC/WP preparation system.

\subsubsection{Off-Normal Operations}

System operations shall be reviewed and potential event sequences shall be identified. The monitoring and control of the systems shall be sufficient so that off-normal conditions that could lead to events are identified such that actions (either automatic or manual) to prevent or mitigate the condition can be initiated. Procedures shall be developed to assure proper response to the off-normal condition and operations personnel shall be trained, staffing the required locations to handle these conditions (Section 3.1.1.4.1).

Internal and external hazards have been identified in the Monitored Geologic Repository External Events Hazards Screening Analysis (BSC 2004 [DIRS 167266]; Internal Hazards Analysis for License Application (BSC 2005 [DIRS 171428]), and event sequences identified in Categorization of Event Sequences for License Application (BSC 2004 [DIRS 167268]). These event sequences are considered when identifying SSCs that are ITS. Other off-normal events can impact plant operations that have no safety impact. The SSCs that are ITS and ITWI are provided in Q-list (BSC 2005 [DIRS 171190]).

Recovery devices for several pieces of equipment, including waste package trolleys and cranes, are planned. A cable system is planned to retrieve trolleys in an off-normal situation. Details will be added as the design develops (Section 3.1.1.4.2). 


\subsubsection{Dry Transfer Facility}

Reliability analyses such as FMEAs or fault trees can be used to evaluate the main failures potentially occurring during system operations in order to identify the configurations with safety concerns. FMEAs identify potential failure modes along with causes, effects on safety, and possible prevention and mitigation SSCs and administrative controls. Preliminary FMEAs in Dry Transfer Facility - WP Handling Crane Failure Mode and Effect Analysis (Areva 2004 [DIRS 170101]); Dry Transfer Facility - Waste Package Trolley Failure Mode and Effects Analysis (Areva 2004 [DIRS 170102]); Dry Transfer Facility - Spent Fuel Transfer Machine Failure Mode and Effects Analysis (Areva 2004 [DIRS 170104]); Dry Transfer Facility (DTF) Waste Package Turntable - Failure Mode and Effects Analysis (Areva 2004 [DIRS 170107]); Dry Transfer Facility-Cask and WP Docking Stations - Failure Mode and Effects Analysis (Cogema 2004 [DIRS 170103]); Dry Transfer Facility (DTF) - Canister/HLW Handling Crane Failure Mode and Effects Analysis (Cogema 2004 [DIRS 170105]); and Dry Transfer Facility (DTF) - Waste Package Tilting Machine - Failure Mode and Effects Analysis (Cogema 2004 [DIRS 170106]), based on the existing and similar designs, have been performed for the following equipment for the SNF/HLW transfer system, relating to the DTF:

- Waste package trolley

- Waste package handling crane

- Casks and waste package docking stations

- SFTM

- Canister/HLW handling crane

- Waste package tilting machine

- Waste package turntable.

\subsubsection{Canister Handling Facility}

Reliability analyses such as FMEAs or fault trees can be used to evaluate the main failures potentially occurring during system operations in order to identify the configurations with safety concerns. FMEAs identify potential failure modes along with causes, effects on safety, and possible prevention and mitigation SSCs and administrative controls. Preliminary FMEAs in Canister Handling Facility (CHF) Waste Package (WP) and Canister Handling Crane Failure Mode and Effects Analysis (Cogema 2003 [DIRS 170096]); Canister Handling Facility (CHF) Waste Package (WP) Trolley Failure Mode and Effects Analysis (Cogema 2003 [DIRS 170098]); Canister Handling Facility (CHF) Waste Package (WP) Tilting Machine Failure Mode and Effects Analysis (Cogema 2003 [DIRS 170099]); and Canister Handling Facility (CHF) Waste Package (WP) Turntable Failure Mode and Effects Analysis (Cogema 2003 [DIRS 170100]), based on the existing and similar designs, have been performed for the following equipment for the SNF/HLW transfer system, relating to the CHF:

- Waste package and canister handling crane

- Waste package trolley

- Waste package turntable

- Waste package tilting machine. 


\subsubsection{Fuel Handling Facility}

Reliability analyses such as FMEAs or fault trees can be used to evaluate the main failures potentially occurring during system operations in order to identify the configurations with safety concerns. FMEAs identify potential failure modes along with causes, effects on safety, and possible prevention and mitigation SSCs and administrative controls. Preliminary FMEAs based on the design, as it exists and existing similar designs are performed for the following equipment for the SNF/HLW transfer system, relating to the FHF:

- Main transfer room crane

- Fuel transfer machine

- Closure transfer trolley

- Waste package turntable

- Waste package tilting machine.

\subsubsection{System Shutdown}

Under certain conditions during operations or just after completion of normal operations, it will be necessary to shut down the system. The sequence and timing of shutdown operations will be described in detail in the system operating procedures.

In general, a system shutdown may be performed by one of the following two means under the conditions indicated:

- Operator request for automatic shutdown or manual shutdown: for production stoppage, freeze mode (safe operating mode) switching, or emergency shutdown

- Automatically in case of process failure or loss of steady-state operating conditions (e.g., a loss of normal power supply).

In the case of shutdown upon operator request, two end states are possible:

- Production stoppage with the operating cycle in a known and steady configuration

- Freeze mode or emergency shutdown mode with the controls and mechanical equipment immediately in a safe and locked position.

Additional details for the system shutdown procedures will be described as the design and operating procedures are further developed.

\subsubsection{Safety Management Programs and Administrative Controls}

The safety management programs and administrative controls invoked on the system are based on applicable requirements from the integrated safety management system. 
Activities involving waste forms or SSCs classified as ITS are conducted in accordance with approved procedures. These procedures provide a planned method of conducting operations that aims to eliminate errors resulting from on-the-spot analyses and judgments.

\subsection{TESTING AND MAINTENANCE}

\subsubsection{Temporary Configurations}

Separate testing and maintenance programs, and temporary configurations will be developed for the system. Details are not yet developed. Appropriate revision of the SDD will incorporate new information when it is available.

\subsubsection{Safety Required Surveillances}

These requirements are based on the final system configuration and its contribution to preclosure and postclosure performance objectives. A review of these considerations will establish the set of necessary surveillances, inspections, and testing requirements.

No surveillances, inspections, and testing requirements have been identified at this time.

Requirements will be determined as the design process matures and the relationship of the system SSCs with repository systems and facilities is defined.

\subsubsection{Non-Safety Inspections and Testing}

Procedures will be developed to define and describe surveillances, inspections, and testing requirements. The procedures will be based on manufacturer recommendations and final system configuration.

\subsubsection{Maintenance}

\subsubsection{Dry Transfer Facility}

Different maintenance principles are applied within the system depending on the equipment and its location in the facility.

- Equipment Inside a Hot Cell-The maintenance principle for equipment installed in the hot cells is to use in-cell cranes, remote master/slave manipulators and, sometimes, specific tools operated from an adjacent room. Damaged pieces of equipment are removed by the in-cell crane with or without support of the master/slave manipulators. The damaged pieces are then sent to the crane park cell where they are conditioned, at a convenient time, to be removed as waste. New pieces of equipment are also introduced into the cell through the crane park cell. Limited maintenance can be performed in the crane park cell, such as component replacement, but extensive repairs are not envisioned. 
In the case of a failure of a master/slave manipulator, it is removed following specific procedures and bagged in tight plastic sleeves. Failed manipulators are transported to a dedicated location for repair.

The SFTM and the canister-handling crane are designed such that, in case of failure, its load can be set down and detached. The crane or SFTM is then sent to the crane park cell to change the failed components. Direct maintenance on the crane in the crane park cell is possible.

- Equipment Outside a Hot Cell-This equipment will be maintained hands-on (direct maintenance).

The design process needs to progress further in order to identify maintenance requirements and a maintenance program for the SNF/HLW transfer system SSCs. The maintenance program for this system will be developed as part of the repository maintenance program.

- System Main Equipment Maintenance Summary-Table 4-3 lists the main equipment and general considerations of maintenance work being performed either directly or remotely on major system components requiring maintenance.

Table 4-4. Dry Transfer Facility SNF/HLW Transfer System Main Equipment Maintenance

\begin{tabular}{|l|c|c|l|}
\hline \multirow{2}{*}{ Main Equipment for Maintenance } & Type of Maintenance & \multirow{2}{*}{ Remarks } \\
\cline { 2 - 3 } $\begin{array}{l}\text { Shielded crane park cell doors and personnel } \\
\text { access to crane park cells }\end{array}$ & Direct & Remote & \\
\hline Maintenance cranes above the crane park cells & $X$ & & Above each crane park cell \\
\hline 70- ton Navy Canister Handling Crane & $X$ & & $\begin{array}{l}\text { In crane park cell with } \\
\text { access authorization }\end{array}$ \\
\hline Naval Canister Grapple & $X$ & & $\begin{array}{l}\text { In crane park cell with } \\
\text { access authorization }\end{array}$ \\
\hline Naval Cask Lid Grapple & $X$ & $\begin{array}{l}\text { In crane park cell with } \\
\text { access authorization }\end{array}$ \\
\hline Cask Trolleys & $X$ & & With access authorization \\
\hline Waste Package Trolleys & $X$ & & $\begin{array}{l}\text { In crane park cell with } \\
\text { access authorization }\end{array}$ \\
\hline SFTM & $X$ & $\begin{array}{l}\text { In crane park cell with } \\
\text { access authorization }\end{array}$ \\
\hline SFTM PWR and BWR Grapples & $X$ & $\begin{array}{l}\text { In crane park cell with } \\
\text { access authorization }\end{array}$ \\
\hline 70-ton Canister/HLW (and DPC) Handling Crane & $X$ & $\begin{array}{l}\text { In crane park cell with } \\
\text { access authorization }\end{array}$ \\
\hline DOE SNF and DOE HLW Canister Grapples & $X$ & $\begin{array}{l}\text { In crane park cell with } \\
\text { access authorization }\end{array}$ \\
\hline MCO Grapple & $X$ & & \\
\hline DPC Docking Station & & & \\
\hline DPC Cutting Station & & & \\
\hline
\end{tabular}


Table 4-3. Dry Transfer Facility SNF/HLW Transfer System Main Equipment Maintenance (Continued)

\begin{tabular}{|c|c|c|c|}
\hline \multirow[b]{2}{*}{ Main Equipment for Maintenance } & \multicolumn{2}{|c|}{ Type of Maintenance } & \multirow[b]{2}{*}{ Remarks } \\
\hline & Direct & Remote & \\
\hline DPC Lifting Yoke & $x$ & & $\begin{array}{l}\text { In crane park cell with } \\
\text { access authorization }\end{array}$ \\
\hline DPC Grapple & $x$ & & $\begin{array}{l}\text { In crane park cell with } \\
\text { access authorization }\end{array}$ \\
\hline DPC Lid Grapple & $x$ & & $\begin{array}{l}\text { In crane park cell with } \\
\text { access authorization }\end{array}$ \\
\hline Cask Docking Stations & $\mathrm{X}$ & $\mathrm{X}$ & \\
\hline Waste Package Docking Stations & $\mathrm{X}$ & $\mathrm{X}$ & \\
\hline Manipulator Work Stations & $\mathrm{X}$ & $x$ & In dedicated area \\
\hline Waste Package Inner Lid Grapple & $x$ & & $\begin{array}{l}\text { In crane park cell with } \\
\text { access authorization }\end{array}$ \\
\hline Docking Ring Grapple & $x$ & & $\begin{array}{l}\text { In crane park cell with } \\
\text { access authorization }\end{array}$ \\
\hline 100-ton Waste Package Handling Crane & $x$ & & $\begin{array}{l}\text { In crane park cell with } \\
\text { access authorization }\end{array}$ \\
\hline Waste Package Lifting Yoke & $x$ & & $\begin{array}{l}\text { In crane park cell with } \\
\text { access authorization }\end{array}$ \\
\hline Waste Package Trolley (to Closure) & $\mathrm{X}$ & & With access authorization \\
\hline $\begin{array}{l}\text { Waste Package Trolley (to Decon and Waste } \\
\text { Package Remediation) }\end{array}$ & $\mathrm{X}$ & & With access authorization \\
\hline Waste Package Trolley (to loadout) & $\mathrm{X}$ & & With access authorization \\
\hline 100-ton Waste Package loadout Handling Crane & $\mathrm{x}$ & & $\begin{array}{l}\text { In crane park cell with } \\
\text { access authorization }\end{array}$ \\
\hline Waste Package Lifting Yoke & $x$ & & $\begin{array}{l}\text { In crane park cell with } \\
\text { access authorization }\end{array}$ \\
\hline Waste Package Tilting Machine & $\mathrm{X}$ & & With access authorization \\
\hline Waste Package Turntable & $\mathrm{X}$ & & With access authorization \\
\hline Trunnion Collar Removal Machine & $\mathrm{X}$ & & With access authorization \\
\hline 5-ton Trunnion Collar Crane & $\mathrm{X}$ & & With access authorization \\
\hline Trunnion Collar Grapple & $\mathrm{X}$ & & With access authorization \\
\hline
\end{tabular}

NOTE: Additional equipment may be added to the maintenance list as the design progresses. Direct maintenance is performed by direct contact on equipment. Remote maintenance is performed with master/slave manipulators, crane, and specific tools from another cell. A combination of remote/direct methods may be used in some cases to put the equipment in a configuration for direct maintenance. This table excludes recovery operations.

\subsubsection{Canister Handling Facility}

The CHF has low potential for contamination. Maintenance on the facility equipment is either performed directly and when radiation sources are shielded or not present or remotely using cranes and master/slave manipulators. The facility is designed so that the radiation sources can be isolated behind shielding or removed, even in the event of equipment failure. Routine and planned maintenance is performed with access authorization and at convenient times when sources are shielded or not present. Table 4-4 lists the main equipment and general considerations of maintenance work being performed either directly or remotely on major system components requiring maintenance. 
Table 4-5. Canister Handling Facility SNF/HLW Transfer System Main Equipment Maintenance

\begin{tabular}{|l|c|c|l|}
\hline \multicolumn{1}{|c|}{ Main Equipment for Maintenance } & Type of Maintenance & \multirow{2}{*}{ Remarks } \\
\cline { 2 - 3 } & Direct & Remote & \multirow{2}{*}{$\begin{array}{l}\text { In crane park area with } \\
\text { access authorization }\end{array}$} \\
\hline Waste Package and Canister Handling Crane & $\mathrm{X}$ & \multirow{2}{*}{ With access authorization } \\
\hline $\begin{array}{l}\text { DOE SNF Canister, DOE HLW Canister, DPC, MCO } \\
\text { Cask Lid, Site-Specific Cask Lid and Pit Plugs grapples }\end{array}$ & $\mathrm{X}$ & & With access authorization \\
\hline Waste Package Lifting Yoke & $\mathrm{X}$ & & With access authorization \\
\hline Waste Package Trolley & $\mathrm{X}$ & & With access authorization \\
\hline Waste Package Tilting Machine & $\mathrm{X}$ & & With access authorization \\
\hline Waste Package Turntable & $\mathrm{X}$ & & With access authorization \\
\hline Collar Removal Machine & $\mathrm{X}$ & & In dedicated area \\
\hline Master/Slave Manipulators & $\mathrm{X}$ & & \\
\hline Maintenance Crane over Crane Park Area & $\mathrm{X}$ & & \\
\hline
\end{tabular}

NOTE: Additional equipment may be added to the maintenance list as the design progresses. Direct maintenance is performed by direct contact on equipment. Remote maintenance is performed with master/slave manipulators, cranes, and specific tools designed for the purpose. This table excludes recovery operations.

\subsubsection{Fuel Handling Facility}

The FHF has a high potential for contamination but decontamination features will allow personnel entry after decontamination is performed. Maintenance on the facility equipment is either performed directly and when radiation sources are shielded or not present or remotely using cranes and master/slave manipulators. The facility is designed so that the radiation sources can be isolated behind shielding or placed in cask for temporary storage, even in the event of equipment failure. Routine and planned maintenance is performed with access authorization and at convenient times when sources are shielded or not present

System Main Equipment Maintenance Summary-Table 4-5 lists the main equipment and general considerations of maintenance work being performed either directly or remotely on major system components requiring maintenance. 
Table 4-6. Fuel Handling Facility SNF/HLW Transfer System Main Equipment Maintenance

\begin{tabular}{|c|c|c|c|}
\hline \multirow[b]{2}{*}{ Main Equipment for Maintenance } & \multicolumn{2}{|c|}{ Type of Maintenance } & \multirow[b]{2}{*}{ Remarks } \\
\hline & Direct & Remote & \\
\hline Main Transfer Room Crane & $\mathrm{X}$ & & With access authorization \\
\hline $\begin{array}{l}\text { DOE SNF Canister, DOE HLW Canister, DPC Lid, Site- } \\
\text { Specific Cask Lid and Shield Plugs Grapples }\end{array}$ & $\mathrm{x}$ & $\mathrm{X}$ & With access authorization \\
\hline Spent Fuel Transfer Machine & $\mathrm{x}$ & $\mathrm{X}$ & With access authorization \\
\hline Fuel Transfer Maintenance Crane & $x$ & & With access authorization \\
\hline Waste Package Lifting Yoke & $\mathrm{X}$ & & With access authorization \\
\hline Waste Package Transfer Trolley & $\mathrm{X}$ & & With access authorization \\
\hline Waste Package Tilting Machine & $\mathrm{X}$ & & With access authorization \\
\hline Waste Package Turntable & $\mathrm{X}$ & & With access authorization \\
\hline Collar Removal Machine & $\mathrm{X}$ & & With access authorization \\
\hline Master/Slave Manipulators & $\mathrm{X}$ & & In dedicated area \\
\hline
\end{tabular}

NOTE: Additional equipment may be added to the maintenance list as the design progresses. Direct Maintenance is performed by direct contact on equipment. Remote Maintenance is performed with master-slave manipulators, cranes, and specific tools designed for the purpose. This table excludes recovery operations.

\subsubsection{Implementation of Maintenance Program}

The relationship of SSCs in a maintenance program is documented in the DOE maintenance program outlined in DOE O 433.1, Maintenance Management Program for DOE Nuclear Facilities [DIRS 163898]. Service cycles for each piece of equipment should be determined with collaboration of the specific manufacturers/vendors.

To maintain the required level of safety and reliability within the system, the maintenance for individual SSCs requires a thorough systematic evaluation. Maintenance is constituted by a set of actions that assure continued operation of the equipment within given tolerances and performance measures. Related maintenance documentation must satisfy correct equipment line-up, setup, preparation, and provide a record of operation to traceable performance tolerances.

- The preventive maintenance principle can be characterized as systematic or conditional. Systematic maintenance is a process by which consumables are routinely changed after a given number of operational cycles. Conditional maintenance, on the other hand, is a process by which an SSC is diagnosed for wear and evaluated against performance tolerances.

- Additionally, the corrective maintenance principle is simply the replacement or repair of failed SSCs or those that have exceeded wear tolerances. Components replaced under corrective maintenance are tracked so that it is possible to tag similar equipment as potential candidates for conditional maintenance under the preventive maintenance principle.

All maintenance activities are coordinated to maintain and manage a spare part inventory. 
Different system maintenance approaches for both preventive and corrective maintenance are applied depending on the equipment, its functions, operational characteristics and location within the building. Details of maintenance procedures based on these approaches will be available once the design and the operations and maintenance procedures are complete.

Experience shows that preventive and corrective maintenance may be implemented by both direct and remote methods.

\subsubsection{Post Maintenance Testing}

After maintenance is performed, specific procedures for testing of the equipment are required to assure continued compliance with respect to nuclear safety design bases. Post maintenance testing procedures will be developed as the design evolves. In all cases, configuration management will apply; that is, quality inspections and checks to conform to "Fit-FormFunction" apply to all SSCs under the maintenance program. 


\section{REFERENCES}

\subsection{DOCUMENTS CITED}

154039 YMP (Yucca Mountain Site Characterization Project) 2000. Environmental Management Plan. YMP/93-04, Rev. 4. Las Vegas, Nevada: Yucca Mountain Site Characterization Office. ACC: MOL.20000831.0064.

155183 BSC (Bechtel SAIC Company) 2001. ALARA Management Commitment and Policy. POL-MG-007, Rev. 0. Las Vegas, Nevada: Bechtel SAIC Company. ACC: MOL.20010530.0150.

155970 DOE (U.S. Department of Energy) 2002. Final Environmental Impact Statement for a Geological Repository for the Disposal of Spent Nuclear Fuel and High-Level Radioactive Waste at Yucca Mountain, Nye County, Nevada. Washington, D.C.: U.S. Department of Energy, Office of Civilian Radioactive Waste Management. ACC: MOL.20020424.0314.

159184 BSC (Bechtel SAIC Company) 2002. YMP ALARA Program. PLN-MGR-MD000001 REV 00. Las Vegas, Nevada: Bechtel SAIC Company. ACC: MOL.20020416.0049.

166275 Canori, G.F. and Leitner, M.M. 2003. Project Requirements Document. TER-MGRMD-000001 REV 02. Las Vegas, Nevada: Bechtel SAIC Company. ACC: DOC.20031222.0006.

167266 BSC (Bechtel SAIC Company) 2004. Monitored Geologic Repository External | Events Hazards Screening Analysis. 000-00C-MGR0-00500-000-00A. Las Vegas, Nevada: Bechtel SAIC Company. ACC: ENG.20040712.0004.

167268 BSC (Bechtel SAIC Company) 2004. Categorization of Event Sequences for License Application. 000-00C-MGR0-00800-000-00A. Las Vegas, Nevada: Bechtel SAIC Company. ACC: ENG.20040722.0001.

167313 BSC (Bechtel SAIC Company) 2004. Preliminary Hazards Analysis for License Application Study. 000-30R-HPYK-00100-000-00A. Las Vegas, Nevada: Bechtel SAIC Company. ACC: ENG.20040610.0002.

167614 BSC (Bechtel SAIC Company) 2004. Canister Handling Facility Criticality Safety Calculations. 190-00C-CH00-00100-000-00A. Las Vegas, Nevada: Bechtel SAIC Company. ACC: ENG.20040302.0017.

168132 BSC (Bechtel SAIC Company) 2004. Surface Facility Criticality Safety Calculations. 100-00C-WHS0-00100-000-00B. Las Vegas, Nevada: Bechtel SAIC Company. ACC: ENG.20040309.0001. 
168814 BSC (Bechtel SAIC Company) 2004. Canister Handling Facility Fire Hazard Analysis. 190-30R-PF00-00100-000-00A. Las Vegas, Nevada: Bechtel SAIC Company. ACC: ENG.20050311.0001.

170096 Cogema. 2003. Canister Handling Facility (CHF) Waste Package (WP) and Canister Handling Crane Failure Mode and Effects Analysis. COGEMA-C0115-EN-FMEA102, Rev. A. Las Vegas, Nevada: COGEMA. ACC: ENG.20040123.0218.

170098 Cogema. 2003. Canister Handling Facility (CHF) Waste Package (WP) Trolley Failure Mode and Effects Analysis. COGEMA-C0115-EN-FMEA-103, Rev. A. Las Vegas, Nevada: COGEMA. ACC: ENG.20040123.0219.

170099 Cogema. 2003. Canister Handling Facility (CHF) Waste Package (WP) Tilting Machine Failure Mode and Effects Analysis. COGEMA-C0115-EN-FMEA-104, Rev. A. Las Vegas, Nevada: COGEMA. ACC: ENG.20040123.0220.

170100 Cogema. 2003. Canister Handling Facility (CHF) Waste Package (WP) Turntable Failure Mode and Effects Analysis. COGEMA-C0115-EN-FMEA-105, Rev. A. Las Vegas, Nevada: COGEMA. ACC: ENG.20040123.0221.

170101 Areva. 2004. Dry Transfer Facility - WP Handling Crane Failure Mode and Effect Analysis. COGEMA-C0115-EN-FMEA-002, Rev. B. Las Vegas, Nevada: Areva. ACC: ENG.20040419.0002.

170102 Areva. 2004. Dry Transfer Facility - Waste Package Trolley Failure Mode and Effects Analysis. COGEMA-C0115-EN-FMEA-003, Rev. A. Las Vegas, Nevada: Areva. ACC: ENG.20040419.0013.

170103 Cogema. 2004. Dry Transfer Facility - Cask and WP Docking Stations - Failure Mode and Effects Analysis. COGEMA-C0115-EN-FMEA-004, Rev. A. Las Vegas, Nevada: COGEMA. ACC: ENG.20040329.0021.

170104 Areva. 2004. Dry Transfer Facility - Spent Fuel Transfer Machine Failure Mode and Effects Analysis. COGEMA-C0115-EN-FMEA-008, Rev. A. Las Vegas, Nevada: Areva. ACC: ENG.20040419.0016.

170105 Cogema. 2004. Dry Transfer Facility (DTF) - Canister/HLW Handling Crane Failure Mode and Effects Analysis. COGEMA-C0115-EN-FMEA-009, Rev. A. Las Vegas, Nevada: COGEMA. ACC: ENG.20040419.0017.

170106 Cogema. 2004. Dry Transfer Facility (DTF) - Waste Package Tilting Machine Failure Mode and Effects Analysis. COGEMA-C0115-EN-FMEA-010, Rev. A. Las Vegas, Nevada: COGEMA. ACC: ENG.20040419.0018.

170107 Areva. 2004. Dry Transfer Facility (DTF) - Waste Package Turntable - Failure Mode and Effects Analysis. COGEMA-C0115-EN-FMEA-012, Rev. A. Las Vegas, Nevada: Areva. ACC: ENG.20040419.0019. 
170273 BSC (Bechtel SAIC Company) 2004. Dry Transfer Facility \#1 /Remediation Facility General Arrangement Legend and General Notes. 110-P10-WHS0-00101-000-00B. Las Vegas, Nevada: Bechtel SAIC Company. ACC: ENG.20040623.0004.

170557 Curry, P.M. 2004. Project Functional and Operational Requirements. TDR-MGRME-000003 REV 02. Las Vegas, Nevada: Bechtel SAIC Company. ACC: DOC.20040714.0003.

170938 BSC (Bechtel SAIC Company) 2004. Thermal Analysis of the Canister Pits and Staging Area. 190-MAC-VN00-00400-000-00A. Las Vegas, Nevada: Bechtel SAIC Company. ACC: ENG.20040716.0001.

171190 BSC (Bechtel SAIC Company) 2005. Q-List. 000-30R-MGR0-00500-000-001. Las Vegas, Nevada: Bechtel SAIC Company. ACC: ENG.20050217.0010.

171428 BSC (Bechtel SAIC Company) 2005. Internal Hazards Analysis for License Application. 000-00C-MGR0-00600-000-00B. Las Vegas, Nevada: Bechtel SAIC Company. ACC: ENG.20050217.0009.

171512 BSC (Bechtel SAIC Company) 2005. Nuclear Safety Design Bases for License Application. 000-30R-MGR0-00400-000-000 REV 01. Las Vegas, Nevada: Bechtel SAIC Company.

171539 DOE (U.S. Department of Energy) 2004. Quality Assurance Requirements and Description. DOE/RW-0333P, Rev. 16. Washington, D.C.: U.S. Department of Energy, Office of Civilian Radioactive Waste Management. ACC: DOC.20040907.0002.

171599 BSC (Bechtel SAIC Company) 2004. Project Design Criteria Document. 000-3DRMGR0-00100-000-003. Las Vegas, Nevada: Bechtel SAIC Company. ACC: ENG.20041124.0001.

171668 BSC (Bechtel SAIC Company) 2005. Safety Classification of SSCs and Barriers. 000-00C-MGR0-01000-000-000. Las Vegas, Nevada: Bechtel SAIC Company. ACC: ENG.20050215.0007.

171778 BSC (Bechtel SAIC Company). 2004. DTF 1 Thermal Analysis of the Staging Cell. 110-00C-VN00-00200-000-00A. Las Vegas, Nevada: Bechtel SAIC Company. ACC: ENG.20040730.0001

171808 BSC (Bechtel SAIC Company) 2004. Canister Handling Facility General Arrangement Legend and General Notes. 190-P10-CH00-00101-000-00B. Las Vegas, Nevada: Bechtel SAIC Company. ACC: ENG.20040914.0016.

171814 BSC (Bechtel SAIC Company) 2004. Fuel Handling Facility General Arrangement Legend and General Notes. 210-P10-FH00-00101-000-00B. Las Vegas, Nevada: Bechtel SAIC Company. ACC: ENG.20040914.0005. 
172147 BSC (Bechtel SAIC Company) 2004. Fuel Handling Facility Fire Hazard Analysis. 210-30R-PF00-00100-000-00B. Las Vegas, Nevada: Bechtel SAIC Company. ACC: ENG.20041122.0002.

172805 BSC (Bechtel SAIC Company) 2005. Dry Transfer Facility No.1 - Fire Hazard Analysis. 110-30R-PF00-00100-000-00C. Las Vegas, Nevada: Bechtel SAIC Company. ACC: ENG.20050214.0005.

\subsection{CODES, STANDARDS, REGULATIONS, AND PROCEDURES}

102016 ANSI N14.6-1993. American National Standard for Radioactive Materials - Special Lifting Devices for Shipping Containers Weighing 10000 Pounds (4500 kg) or More. New York, New York: American National Standards Institute. TIC: ANSI N14.61993. American National Standard for Radioactive Materials - Special Lifting Devices for Shipping Containers Weighing 10000 Pounds (4500 kg) or More. New York, New York: American National Standards Institute. TIC: 236261.

103312 Regulatory Guide 8.8, Rev. 3. 1978. Information Relevant to Ensuring that Occupational Radiation Exposures at Nuclear Power Stations Will be as Low as is Reasonably Achievable. Washington, D.C.: U.S. Nuclear Regulatory Commission. Readily available.

10402664 FR 30851. Greening the Government Through Efficient Energy Management. Executive Order 13123. Readily available.

153997 CMAA 70-2000. Specifications for Top Running Bridge and Gantry Type Multiple Girder Electric Overhead Traveling Cranes. Charlotte, North Carolina: Crane Manufacturers Association of America. TIC: 249445.

15626710 CFR 435. 1995 Energy: Energy Conservation Voluntary Performance Standards for New Buildings; Mandatory for Federal Buildings. Readily available

158835 ANSI/AISC N690-1994. 1994. American National Standard Specification for the Design, Fabrication, and Erection of Steel Safety-Related Structures for Nuclear Facilities. Chicago, Illinois: American Institute of Steel Construction. TIC: 252734

158891 ASME NOG-1-2002. 2002. Rules for Construction of Overhead and Gantry Cranes (Top Running Bridge, Multiple Girder). New York, New York: American Society of Mechanical Engineers. TIC: 252907.

158913 DOE O 430.2A. 2002. Departmental Energy and Utilities Management. Washington, D.C.: U.S. Department of Energy. Readily available.

161567 DOE O 450.1. 2003. Environmental Protection Program. Washington, D.C.: U.S. Department of Energy. 
163274 NRC (U.S. Nuclear Regulatory Commission) 2003. Yucca Mountain Review Plan, Final Report. NUREG-1804, Rev. 2. Washington, D.C.: U.S. Nuclear Regulatory Commission, Office of Nuclear Material Safety and Safeguards. TIC: 254568.

163898 DOE O 433.1. 2001. Maintenance Management Program for DOE Nuclear Facilities. Washington, D.C.: U.S. Department of Energy. Readily available.

164162 T1.105-2001. 2002. Synchronous Optical Network (SONET) -- Basic Description Including Multiplex Structure, Rates, and Formats, Including Supplement T1.105a2002. Washington, D.C.: Alliance for Telecommunications Industry Solutions. TIC: 254657.

166812 ISO/IEC 13818-1:2000(E). 2000. Information Technology - Generic Coding of | Moving Pictures and Associated Audio Information: Systems. Geneva, Switzerland: International Organization for Standardization. TIC: 254395.

166813 ISO/IEC 13818-2:2000(E). 2000. Information Technology - Generic Coding of Moving Pictures and Associated Audio Information: Video. Geneva, Switzerland: International Organization for Standardization. TIC: 254947.

166814 ISO/IEC 13818-3:1998(E). 1998. Information Technology - Generic Coding of Moving Pictures and Associated Audio Information - Part 3: Audio. 2nd Edition. Geneve, Switzerland: International Organization for Standardization. TIC: 254950.

17125310 CFR 72. 2004 Energy: Licensing Requirements for the Independent Storage of Spent Nuclear Fuel, High-Level Radioactive Waste, and Reactor-Related Greater than Class C Waste. TIC: 256942.

17130810 CFR 71. 2004 Energy: Packaging and Transportation of Radioactive Material. TIC: 256942.

171688 ASME B30.20-2003. 2003. Below-the-Hook Lifting Devices. New York, New York: American Society of Mechanical Engineers. TIC: 256185.

171846 ASME (American Society of Mechanical Engineers) 2004. 2004 ASME Boiler and Pressure Vessel Code. 2004 Edition. New York, New York: American Society of Mechanical Engineers. TIC: 256479.

17316410 CFR 63. 2004 Energy: Disposal of High-Level Radioactive Wastes in a Geologic Repository at Yucca Mountain, Nevada. ACC: MOL.20050323.0071.

17316510 CFR 20. 2005 Energy: Standards for Protection Against Radiation. ACC: MOL.20050323.0072.

AP-EM-002, Land Access and Environmental Compliance.

AP-EM-010, Environmental Baseline Review. 


\subsection{DATA TRACKING NUMBERS}

No source data are cited in this document.

\subsection{SOFTWARE CODES}

No software codes are cited in this document. 


\section{APPENDIX A GLOSSARY}

\section{Basis}

Canister

Design Criteria

Design Requirement

Dual-Purpose Canister

Empty

Function
Statements that refer to design requirements for SSCs and identify why the requirement exists, why it is specified in a particular manner, and why a specified value is used.

The structure surrounding some forms of waste (e.g., HLW immobilized in glass logs or ceramic disks within cans) that facilitates handling, storage, and transportation. Canistered waste will be placed in waste packages prior to emplacement.

Design criteria are the bases for acceptance of designs, for SSCs to satisfy design requirements. Design criteria consist of the standards, codes, laws, regulations, general discipline design criteria, event sequences, and hazards that are specified for use on the project.

Design requirements are technical requirements, determined by design processes, that define the functions, capabilities, capacities, physical size and configurations, dimensions, performance parameters, limits, set points, etc., and are developed and specified for SSCs to satisfy the mission design input requirements.

Dual-Purpose Canister (DPC)-A sealed metal container used to transfer, store, and transport commercial SNF from a commercial reactor site to the repository. The canister and its transportation cask are licensed by the NRC pursuant to $10 \mathrm{CFR}$ Parts 71 [DIRS 171308] and 72 [DIRS 171253] for storage and transportation. Thus, the term "dual-purpose."

Empty is a term used to describe waste packages and sitespecific casks. Empty waste packages and empty site-specific casks refer to new or unused waste packages and site-specific casks with no contamination.

A function is a statement of the purpose of a system or component. 
Mission Requirement

Site-Specific Cask (MSC)

Off-Normal

Performance Acceptance Criteria

\section{Requirement}

Remediation

\section{Unloaded}

Mission requirements are input design demands requested by the owner/client or imposed by statute or regulation that identify and define for the facility design requirements for performance, functional, operational, and maintenance characteristics or parameters that the facility SSCs are to be designed to satisfy.

A radiation shielded vertical site-specific aging cask (steel or concrete) to accommodate three configurations of waste: 1) commercial SNF assemblies that are received noncanisterized and 2) Certified vertical DPCs that are received canisterized from any BWR or PWR plants and 3) DOE $\mathrm{SNF} / \mathrm{HLW}$ canisters.

Off-normal is a term used to define an occurrence of an event or condition outside the bounds of routine operations but within the range of analyzed conditions for the SSC.

Performance acceptance criteria are statements that provide verifiable measures of how well the design specification has been achieved or limits against which the actual performance capability of the as-built system can be evaluated.

A specification of what the design solution must do. Requirement statements should also include a statement of how well the specification is to be achieved so as to permit verification. In some cases, there are several criteria for measuring the success of the achievement of the specification and these would be listed as performance acceptance criteria.

Remediation is a term to define a recovery strategy to recover from off-normal events involving waste packages, casks, site-specific casks, canisters, SNF/HLW and associated handling devices.

Unloaded is a term to describe casks, waste packages and site-specific casks. Unloaded casks, waste packages, and site-specific casks refer to casks, waste packages, and site-specific casks that have been loaded with waste (used) and were unloaded. Unloaded casks, waste packages and site-specific casks may be contaminated. 
LIST OF KEY SYSTEM CHARTS, DIAGRAMS, DRAWINGS, LISTS, AND ETC.

\begin{tabular}{|c|c|}
\hline Document Identifier & Title \\
\hline YMP-C0115-0506 Sheet 1 & Areva. 2004. SNF/HLW Transfer System Block Flow Diagram Level 2 \\
\hline YMP-C0115-0506 Sheet 2 & Cogema 2003. SNF/HLW Transfer System Block Flow Diagram Level 2 \\
\hline YMP-C0115-0603 Sheet 1 & Areva. 2004. Canister Handling Facility Block Flow Diagram Level 2 \\
\hline YMP-C0115-0603 Sheet 2 & Areva. 2004. Canister Handling Facility Block Flow Diagram Level 2 \\
\hline YMP-C0115-0603 Sheet 3 & Areva. 2004. Canister Handling Facility Block Flow Diagram Level 2 \\
\hline 210-MH0-FH00-00101-000 Sheet 1 & Fuel Handling Facility Block Flow Diagram Level 2 \\
\hline 210-MH0-FH00-00102-000 Sheet 2 & Fuel Handling Facility Block Flow Diagram Level 2 \\
\hline 210-MH0-FH00-00103-000 Sheet 3 & Fuel Handling Facility Block Flow Diagram Level 2 \\
\hline 210-MH0-FH00-00104-000 Sheet 4 & Fuel Handling Facility Block Flow Diagram Level 2 \\
\hline 210-MH0-FH00-00105-000 Sheet 5 & Fuel Handling Facility Block Flow Diagram Level 2 \\
\hline 210-MH0-FH00-00106-000 Sheet 6 & Fuel Handling Facility Block Flow Diagram Level 2 \\
\hline 110-P10-WHS0-00101-000 Sheet 1 & $\begin{array}{l}\text { Dry Transfer Facility \#1 /Remediation Facility General Arrangement Legend and } \\
\text { General Notes }\end{array}$ \\
\hline 110-P10-WHS0-00102-000 Sheet 2 & $\begin{array}{l}\text { Dry Transfer Facility \#1 /Remediation Facility General Arrangement Ground Floor } \\
\text { Key Plan }\end{array}$ \\
\hline
\end{tabular}




\begin{tabular}{|c|c|}
\hline Document Identifier & Title \\
\hline 110-P10-WHS0-00103-000 Sheet 3 & $\begin{array}{l}\text { Dry Transfer Facility \#1 /Remediation Facility General Arrangement Operating } \\
\text { Floor Key Plan }\end{array}$ \\
\hline 110-P10-WHS0-00104-000 Sheet 4 & $\begin{array}{l}\text { Dry Transfer Facility \#1 /Remediation Facility General Arrangement Upper Floor } \\
\text { Key Plan }\end{array}$ \\
\hline 110-P10-WHS0-00105-000 Sheet 5 & Dry Transfer Facility \#1/Remediation Facility General Arrangement Roof Key Plan \\
\hline 110-P10-WHS0-00108-000 Sheet 8 & $\begin{array}{l}\text { Dry Transfer Facility \#1 /Remediation Facility General Arrangement Ground Floor } \\
\text { Plan A }\end{array}$ \\
\hline 110-P10-WHS0-00109-000 Sheet 9 & $\begin{array}{l}\text { Dry Transfer Facility \#1 /Remediation Facility General Arrangement Ground Floor } \\
\text { Plan B }\end{array}$ \\
\hline 110-P10-WHS0-00110-000 Sheet 10 & $\begin{array}{l}\text { Dry Transfer Facility \#1 /Remediation Facility General Arrangement Ground Floor } \\
\text { Plan C }\end{array}$ \\
\hline 110-P10-WHS0-00111-000 Sheet 11 & $\begin{array}{l}\text { Dry Transfer Facility \#1 /Remediation Facility General Arrangement Ground Floor } \\
\text { Plan D }\end{array}$ \\
\hline 110-P10-WHS0-00112-000 Sheet 12 & $\begin{array}{l}\text { Dry Transfer Facility \#1 /Remediation Facility General Arrangement Operating } \\
\text { Floor Plan A }\end{array}$ \\
\hline 110-P10-WHS0-00113-000 Sheet 13 & $\begin{array}{l}\text { Dry Transfer Facility \#1 /Remediation Facility General Arrangement Operating } \\
\text { Floor Plan B }\end{array}$ \\
\hline 110-P10-WHS0-00114-000 Sheet 14 & $\begin{array}{l}\text { Dry Transfer Facility \#1 /Remediation Facility General Arrangement Operating } \\
\text { Floor Plan C }\end{array}$ \\
\hline 110-P10-WHS0-00115-000 Sheet 15 & $\begin{array}{l}\text { Dry Transfer Facility \#1 /Remediation Facility General Arrangement Operating } \\
\text { Floor Plan D }\end{array}$ \\
\hline 110-P10-WHS0-00116-000 Sheet 16 & Dry Transfer Facility \#1 /Remediation Facility General Arrangement Upper Floor \\
\hline
\end{tabular}




\begin{tabular}{|c|c|}
\hline Document Identifier & Title \\
\hline & Plan A \\
\hline 110-P10-WHS0-00117-000 Sheet 17 & $\begin{array}{l}\text { Dry Transfer Facility \#1/Remediation Facility General Arrangement Upper Floor } \\
\text { Plan B }\end{array}$ \\
\hline 110-P10-WHS0-00118-000 Sheet 18 & $\begin{array}{l}\text { Dry Transfer Facility \#1 /Remediation Facility General Arrangement Upper Floor } \\
\text { Plan C }\end{array}$ \\
\hline 110-P10-WHS0-00119-000 Sheet 19 & $\begin{array}{l}\text { Dry Transfer Facility \#1 /Remediation Facility General Arrangement Upper Floor } \\
\text { Plan D }\end{array}$ \\
\hline 110-P10-WHS0-00120-000 Sheet 20 & Dry Transfer Facility \#1 /Remediation Facility General Arrangement Roof Plan A \\
\hline 110-P10-WHS0-00121-000 Sheet 21 & Dry Transfer Facility \#1 /Remediation Facility General Arrangement Roof Plan B \\
\hline 110-P10-WHS0-00122-000 Sheet 22 & Dry Transfer Facility \#1 /Remediation Facility General Arrangement Roof Plan C \\
\hline 110-P10-WHS0-00123-000 Sheet 23 & Dry Transfer Facility \#1 /Remediation Facility General Arrangement Roof Plan D \\
\hline 110-P10-WHS0-00124-000 Sheet 24 & $\begin{array}{l}\text { Dry Transfer Facility \#1 /Remediation Facility General Arrangement Pool Floor } \\
\text { Plans }\end{array}$ \\
\hline 110-P10-WHS0-00128-000 Sheet 28 & Dry Transfer Facility \#1/Remediation Facility General Arrangement Section A \\
\hline 110-P10-WHS0-00129-000 Sheet 29 & Dry Transfer Facility \#1/Remediation Facility General Arrangement Section B \\
\hline 110-P10-WHS0-00130-000 Sheet 30 & Dry Transfer Facility \#1/Remediation Facility General Arrangement Section C \\
\hline 110-P10-WHS0-00131-000 Sheet 31 & Dry Transfer Facility \#1/Remediation Facility General Arrangement Section D \\
\hline 110-P10-WHS0-00132-000 Sheet 32 & Dry Transfer Facility \#1/Remediation Facility General Arrangement Section E \\
\hline 110-P10-WHS0-00133-000 Sheet 33 & Dry Transfer Facility \#1/Remediation Facility General Arrangement Section F \\
\hline
\end{tabular}




\begin{tabular}{|c|c|}
\hline Document Identifier & Title \\
\hline 110-P10-WHS0-00134-000 Sheet 34 & Dry Transfer Facility \#1/Remediation Facility General Arrangement Section G \\
\hline 110-P10-WHS0-00135-000 Sheet 35 & Dry Transfer Facility \#1/Remediation Facility General Arrangement Section H \\
\hline 110-P10-WHS0-00136-000 Sheet 36 & Dry Transfer Facility \#1/Remediation Facility General Arrangement Section J \\
\hline 110-P10-WHS0-00137-000 Sheet 37 & Dry Transfer Facility \#1/Remediaton Facility General Arrangement Section K \\
\hline 110-P10-WHS0-00138-000 Sheet 38 & Dry Transfer Facility \#1/Remediation Facility General Arrangement Section L \\
\hline 110-P10-WHS0-00139-000 Sheet 39 & Dry Transfer Facility \#1/Remediation Facility General Arrangement Section M \\
\hline 110-P10-WHS0-00140-000 Sheet 40 & Dry Transfer Facility \#1/Remediation Facility General Arrangement Section N \\
\hline 110-P10-WHS0-00141-000 Sheet 41 & Dry Transfer Facility \#1/Remediation Facility General Arrangement Section P \\
\hline 110-P10-WHS0-00142-000 Sheet 42 & Dry Transfer Facility \#1 /Remediation Facility General Arrangement Section $R$ \& $S$ \\
\hline 110-U00-AKRP-00101-000 & Dry Transfer Facility \#1 Radiation Classifications Ground Floor \& Basement \\
\hline 110-U00-AKRP-00102-000 & Dry Transfer Facility \#1 Radiation Classifications Operating Floor \\
\hline 110-U00-AKRP-00103-000 & Dry Transfer Facility \#1 Radiation Classifications Upper Floor \\
\hline 190-P10-CH00-00101-000 Sheet 1 & Canister Handling Facility General Arrangement Legend and General Notes \\
\hline 190-P10-CH00-00102-000 Sheet 2 & Canister Handling Facility General Arrangement Key Plan \\
\hline 190-P10-CH00-00103-000 Sheet 3 & Canister Handling Facility General Arrangement Ground Floor Plan \\
\hline 190-P10-CH00-00104-000 Sheet 4 & Canister Handling Facility General Arrangement Pit \& Mezzanine Floor Plans \\
\hline 190-P10-CH00-00105-000 Sheet 5 & Canister Handling Facility General Arrangement Second Floor Plan \\
\hline
\end{tabular}




\begin{tabular}{|c|c|}
\hline Document Identifier & Title \\
\hline 190-P10-CH00-00106-000 Sheet 6 & Canister Handling Facility General Arrangement Third Floor Plan \\
\hline 190-P10-CH00-00107-000 Sheet 7 & Canister Handling Facility General Arrangement Roof Plan \\
\hline 190-P10-CH00-00108-000 Sheet 8 & Canister Handling Facility General Arrangement Sections A \& B \\
\hline 190-P10-CH00-00109-000 Sheet 9 & Canister Handling Facility General Arrangement Section C \& D \\
\hline 190-P10-CH00-00110-000 Sheet 10 & Canister Handling Facility General Arrangement Section E \\
\hline 190-P10-CH00-00111-000 Sheet 11 & Canister Handling Facility General Arrangement Section F \& G \\
\hline 190-P10-CH00-00112-000 Sheet 12 & Canister Handling Facility General Arrangement Section H \& J \\
\hline 190-P10-CH00-00113-000 Sheet 13 & Canister Handling Facility General Arrangement Section K \& L \\
\hline 190-U00-AKRP-00101-000 & Canister Handling Facility Radiation Classifications First Floor \\
\hline 190-U00-AKRP-00102-000 & Canister Handling Facility Radiation Classifications Second Floor \\
\hline 190-U00-AKRP-00103-000 & Canister Handling Facility Radiation Classifications Third Floor \\
\hline 190-U00-AKRP-00104-000 & Canister Handling Facility Radiation Classifications Mezzanine Floor \\
\hline 210-P10-FH00-00101-000 Sheet 1 & Fuel Handling Facility General Arrangement Legend and General Notes \\
\hline 210-P10-FH00-00102-000 Sheet 2 & Fuel Handling Facility General Arrangement Ground Floor Plan \\
\hline 210-P10-FH00-00103-000 Sheet 3 & Fuel Handling Facility General Arrangement Operating Floor Plan \\
\hline 210-P10-FH00-00104-000 Sheet 4 & Fuel Handling Facility General Arrangement Mezzanine Plan \\
\hline 210-P10-FH00-00105-000 Sheet 5 & Fuel Handling Facility General Arrangement Floor Plan @ Elev +64'-0" \\
\hline
\end{tabular}




\begin{tabular}{|c|c|}
\hline Document Identifier & Title \\
\hline 210-P10-FH00-00106-000 Sheet 6 & Fuel Handling Facility General Arrangement Plan @ Elev. 84'-0" \\
\hline 210-P10-FH00-00107-000 Sheet 7 & Fuel Handling Facility General Arrangement Roof Plan \\
\hline 210-P10-FH00-00108-000 Sheet 8 & Fuel Handling Facility General Arrangement Section A \\
\hline 210-P10-FH00-00109-000 Sheet 9 & Fuel Handling Facility General Arrangement Section B \\
\hline 210-P10-FH00-00110-000 Sheet 10 & Fuel Handling Facility General Arrangement Sections $C, D$, \& G \\
\hline 210-P10-FH00-00111-000 Sheet 11 & Fuel Handling Facility General Arrangement Sections E, F, \& H \\
\hline 210-U00-AKRP-00101-000 & Fuel Handling Facility Radiation Classification Ground Floor Plan \\
\hline 210-U00-AKRP-00102-000 & Fuel Handling Facility Radiation Classification Operating Floor Plan \\
\hline 210-U00-AKRP-00103-000 & Fuel Handling Facility Radiation Classification Mezzanine Plan \\
\hline 210-U00-AKRP-00104-000 & Fuel Handling Facility Radiation Classification Plan @ Elev. +64'-0” \\
\hline
\end{tabular}




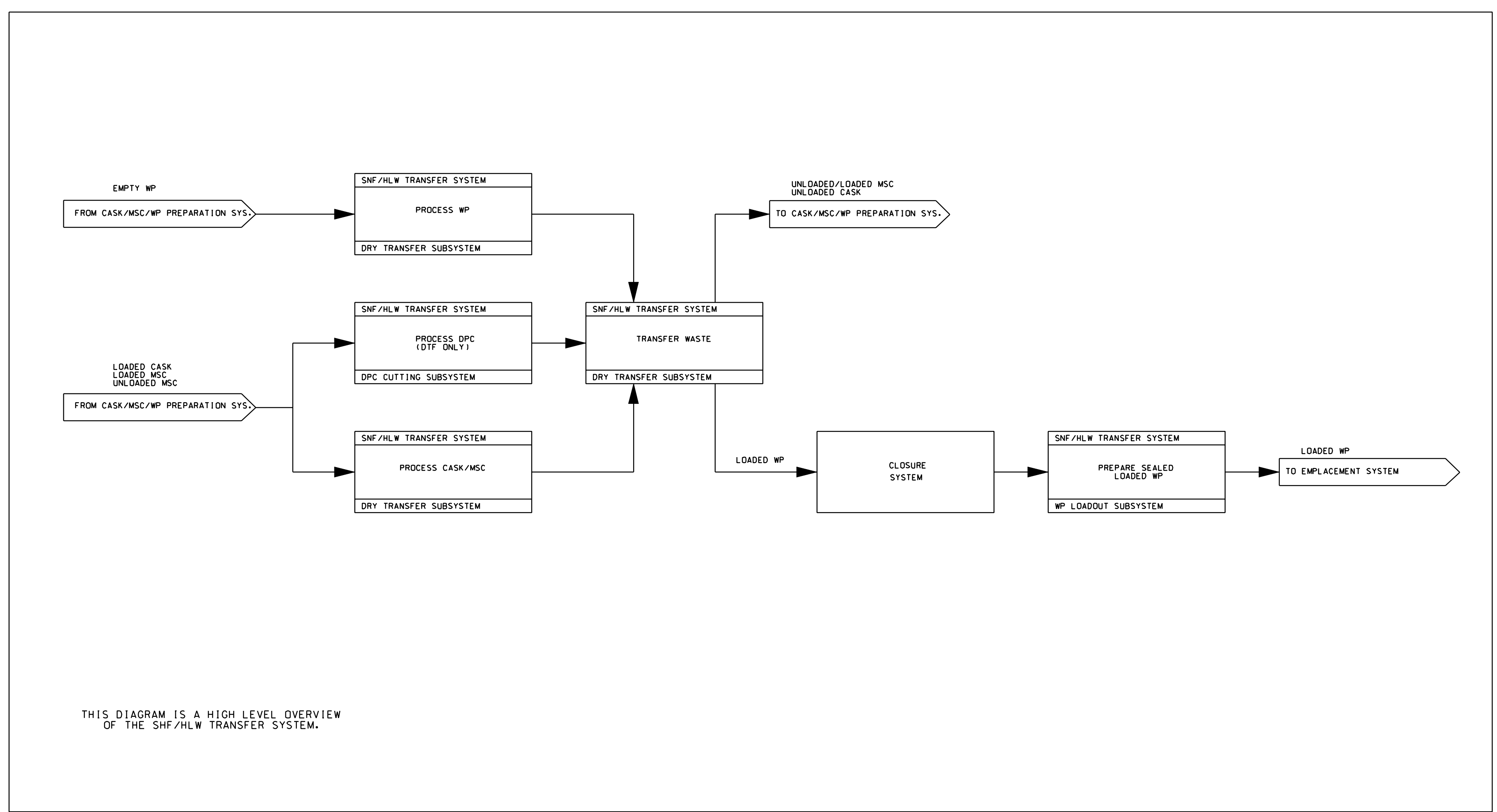




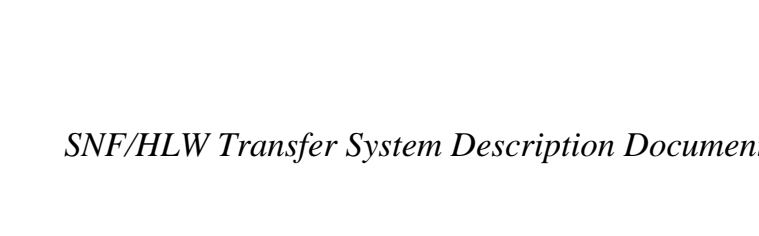

INTENTIONALLY Left BLANK 


\section{APPENDIX C LIST OF SYSTEM PROCEDURES}

This listing will be added to the SDD in a future revision. 


\section{INTENTIONALLY LEFT BLANK}

